\title{
PENGARUH AUDIT DELAY, KONDISI KEUANGAN DAN OPINI AUDIT SEBELUMNYA TERHADAP PENERIMAAN OPINI AUDIT GOING CONCERN
}

\author{
Christina, SE, M.Si \\ christina.harianja@gmail.com
Fakultas Ekonomi dan Bisnis - Program Studi Akuntansi Universitas Satya Negara Indonesia

\begin{abstract}
ABSTRAK
Tujuan penelitian ini untuk mengetahui pengaruh audit delay, kondisi keuangan, dan opini audit sebelumnya terhadap penerimaan audit going concern.

Penelitian ini menggunakan data sekunder yang diperoleh dari laporan keuangan dan laporan auditor independen yang dipublikasikan melalui situs resmi Bursa Efek Indonesia, Sampel penelitian ini adalah perusahaan manufaktur sektor aneka industri yang terdaftar di Bursa Efek Indonesia tahun 2014-2018. Pengambilan sampel dengan menggunakan metode purposive sampling dan diperoleh sebanyak 35 perusahaan yang dijadikan sampel dalam penelitian ini. Pengujian hipotesis dilakukan dengan menggunakan regresi logistik.

Dari hasil pengujian menunjukkan bahwa variabel audit delay dan kondisi keuangan tidak berpengaruh signifikan terhadap penerimaan audit going concern. Variabel opini audit sebelumnya berpengaruh signifikan terhadap penerimaan audit going concern.

Kata kunci : Penerimaan opini audit going concern, audit delay, kondisi keuangan, dan opini audit sebelumnya.
\end{abstract}

\section{ABSTRACT}

This research was conducted with the aim to determine the effect of audit delay, financial condition, and previous audit opinion on going concern audit acceptance.

This study uses secondary data obtained from financial reports and independent auditor's reports which are published through the official website of the Indonesia Stock Exchange. The sample of this research is manufacturing companies various industrial sectors listed on the Indonesia Stock Exchange in 2014-2018. Sampling using purposive sampling method and obtained as many as 35 companies used as samples in this study. Hypothesis testing is done using logistic regression.

The test results show that the audit delay and financial condition variables do not significantly influence the going concern audit acceptance. Previous audit opinion variables significantly influence the going concern audit acceptance.

Keywords : acceptance of audit opinions going concern, audit delay, financial condition, and previous audit opinion. 


\section{PENDAHULUAN}

\section{Latar Belakang}

Saat ini terjadi peningkatan kasus-kasus yang melibatkan manipulasi laporan keuangan. Di Indonesia sendiri perusahaan yang mengalami kebangkrutan misalnya PT Surabaya Agung Industri Pulp dan Kertas Tbk, Suryainti Permata Tbk, PT Aqua Golden Misissipi, Alfa Retailindo Tbk, dsb. Selain itu ada sebuah kasus yang belum lama terjadi di Indonesia, yaitu dari dunia perbankan adalah kasus bank Century atau juga dikenal sebagai bank mutiara. Dalam kasus tersebut auditor tidak bertindak secara profesional dalam auditnya, Adanya persekongkolan antara pihak dalam dengan pihak auditor. Dalam hal ini auditor dianggap ikut andil dalam memberikan informasi yang salah, sehingga banyak pihak yang merasa dirugikan.

Masalah timbul ketika banyak terjadi kesalahan opini (audit failures) yang dibuat oleh auditor menyangkut opini going concern (Sekar, 2003). Opini audit going concern merupakan opini yang dikeluarkan auditor untuk memastikan apakah perusahaan dapat mempertahankan kelangsungan hidupnya (SPAP seksi 341, 2011). Auditor harus bertanggung jawab terhadap opini audit going concern yang dikeluarkannya, karena akan mempengaruhi keputusan para pemakai laporan keuangan (Setiawan, 2006 dalam Kartika, 2012). Pengeluaran opini audit going concern ini sangat berguna bagi para pemakai laporan keuangan untuk membuat keputusan yang tepat dalam berinvestasi, karena ketika seorang investor akan melakukan investasi ia perlu untuk mengetahui kondisi keuangan perusahaan, terutama yang menyangkut tentang kelangsungan hidup perusahaan. Hal ini membuat auditor mempunyai tanggung jawab yang besar untuk mengeluarkan opini audit going concern yang konsisten dengan keadaan sesungguhnya.

Going concern adalah suatu dalil yang menyatakan bahwa kesatuan usaha akan menjalankan terus operasinya dalam jangka waktu yang cukup lama untuk mewujudkan proyeknya, tanggung jawab dan aktivitas-aktivitasnya yang tidak berhenti. Dalil ini memberi gambaran bahwa suatu entitas akan diharapkan beroperasi untuk jangka waktu yang tidak terbatas atau tidak diarahkan menuju ke arah likuidasi. Suatu entitas dianggap going concern apabila perusahaan dapat melanjutkan operasinya dan memenuhi kewajibannya.

Auditor perlu mempertimbangkan faktor-faktor yang mempengaruhi opini audit going concern untuk menerbitkan opini tersebut. Salah satunya adalah audit delay. Audit delay adalah jangka waktu lamanya penyelesaian audit yang dihitung dalam jumlah hari sejak tanggal akhir periode pembukuan perusahaan sampai tanggal yang tertera dalam laporan auditor independen (Dwi dan Herry, 2013). Mirna dan Indira (2007) menjelaskan bahwa opini audit going concern cenderung akan diberikan auditor ketika penyampaian laporan auditor independen ini terlambat.

Kondisi keuangan termasuk faktor yang mempengaruhi auditor untuk menerbitkan opini audit going concern. Kondisi keuangan perusahaan adalah suatu tampilan atau keadaan secara utuh atas keuangan perusahaan selama periode waktu kurun tertentu. Kondisi keuangan perusahaan menggambarkan tingkat kesehatan perusahaan sesungguhnya (Ramadhany, 2004). Semakin buruk kondisi keuangan perusahaan maka akan semakin besar kemungkinan perusahaan menerima opini 
audit going concern, sebaliknya pada perusahaan yang tidak mengalami kesulitan pada kondisi keuangannya maka auditor tidak mengeluarkan opini audit going concern.

Opini audit sebelumnya adalah Opini yang dikeluarkan oleh auditor ditahun sebelumnya. Kemungkinan besar Auditor akan memberikan opini audit going concern kembali jika melihat perusahaan telah menerima opini audit going concern pada tahun sebelumnya karena dianggap memiliki masalah dalam mempertahankan kelangsungan hidupnya (Septrisnawaty, 2018).

Penelitian ini bertujuan untuk menguji apakah audit delay, kondisi keuangan, dan opini audit sebelumnya berpengaruh terhadap penerimaan opini audit going concern. Berdasarkan uraian latar belakang diatas maka peneliti tertarik untuk melakukan sebuah penelitian dengan judul "Pengaruh Audit Delay, Kondisi Keuangan, dan Opini Audit Sebelumnya terhadap Penerimaan Opini Audit Going Concern".

\section{Perumusan Masalah}

Berdasarkan latar belakang diatas maka dapat dirumuskan masalah penelitian sebagai berikut :

1. Apakah audit delay berpengaruh terhadap penerimaan opini audit going concern?

2. Apakah kondisi keuangan berpengaruh terhadap penerimaan opini audit going concern?

3. Apakah opini audit sebelumnya berpengaruh terhadap penerimaan opini audit going concern?

4. Apakah audit delay, kondisi keuangan, dan opini audit sebelumnya berpengaruh terhadap penerimaan opini audit going concern?

\section{Tujuan penelitian}

Tujuan penelitian ini adalah sebagai berikut :

a. Untuk mengetahui apakah audit delay berpengaruh terhadap penerimaan opini audit going concern.

b. Untuk mengetahui apakah kondisi keuangan berpengaruh terhadap penerimaan opini audit going concern.

c. Untuk mengetahui apakah opini audit sebelumnya berpengaruh terhadap penerimaan opini audit going concern.

d. Untuk mengetahui apakah audit delay, kondisi keuangan, dan opini audit sebelumnya berpengaruh terhadap penerimaan opini audit going concern.

\section{Manfaat Penelitian}

Penelitian ini diharapkan dapat memberikan manfaat yang berguna bagi berbagai pihak, yaitu:

a. Kegunaan Teoritis :

Dari penelitian ini diharapkan dapat memberikan tambahan informasi dan ilmu pengetahuan tentang penerimaan opini audit going concern bagi para akademis.

b. Kegunaan Praktis :

1) Bagi Peneliti 
Untuk menambah wawasan dan pengetahuan mengenai pengaruh audit delay, kondisi keuangan, dan opini audit sebelumnya terhadap penerimaan opini audit going concern.

2) Bagi Pembaca

Penelitian ini diharapkan dapat menambah informasi dan ilmu tentang penerimaan opini audit going concern bagi pembaca.

3) Bagi Manajemen Perusahaan

Penelitian ini diharapkan mampu memberikan kontribusi untuk memberikan gambaran tentang faktor-faktor yang mempengaruhi penerimaan opini audit going concern.

\section{LANDASAN TEORI}

\section{Auditing}

Menurut Arens (2003:15) Audit yaitu pengumpulan serta pengevaluasian bukti-bukti atas informasi untuk menentukan dan melaporkan tingkat kesesuaian informasi tersebut dengan kriteria-kriteria yang ditetepkan. Adapun auditing dilakukan oleh seorang yang kompeten dan independen.

Auditing menurut Agoes (2011:4) merupakan suatu pemeriksaan yang dilakukan secara kritis dan sistematis, oleh pihak yang independen, terhadap laporan keuangan yang telah disusun untuk manajemen, beserta catatan-catatan pembukuan dan bukti-bukti pendukungnya, dengan tujuan untuk dapat meberikan pendapat mengenai kewajaran laporan keuangan tersebut.

\section{Audit Delay}

Menurut Lawrence dan Briyan (1988) dalam Ani Yulianti (2011), "keterlambatan audit adalah lamanya hari yang dibutuhkan auditor untuk menyelesaikan pekerjaan auditnya, yang diukur dari tanggal penutupan tahun buku hingga tanggal diterbitkannya laporan keuangan audit". keterlambatan audit atau dalam beberapa penelitian disebut sebagai audit reporting lag didefinisikan sebagai selisih waktu antara berakhirnya tahun fiskal dengan tanggal diterbitkannya laporan audit.

Ketepatan waktu penerbitan laporan keuangan yang telah diaudit merupakan hal yang krusial terutama bagi perusahaan-perusahaan publik yang menggunakan pasar modal sebagai salah satu sumber pendanaan. Ketepatan waktu penerbitan laporan keuangan tahunan perusahaan juga dapat menimbulkan pengaruh kepada nilai dari laporan keuangan tersebut (Panjaitan,2010). Keterlambatan publikasi laporan keuangan mengindikasikan adanya masalah dalam laporan keuangan dalam perusahaan, sehingga memerlukan waktu yang lebih lama dalam penyelesaian audit. Lebih lama audit delay, auditor dapat menggali informasi lebih banyak lagi, sehingga kemungkinan besar auditor akan menemukan bukti bukti yang cukup untuk mengeluarkan opini audit going concern.

Bagi perusahaan - perusahaan yang go public, laporan keuangan yang disajikan wajib diaudit oleh Kantor Akuntan Publik, yang kemudian laporan keuangan tersebut akan dipublikasikan disertai dengan laporan auditor independen paling lama 90 hari atau pada akhir bulan ketiga setelah tanggal laporan keuangan tahunan. Hal ini sebagaimana dijelaskan dalam Peraturan Bapepam Nomor X.K.2, Lampiran Keputusan Ketua Bapepam Nomor:KEP-346/BL/2011, Tentang, 
Penyampaian Laporan Keuangan Berkala Emiten atau Perusahaan Publik. Pada tahun 2016 Bapepam yang sekarang menjadi Otoritas Jasa Keuangan merevisi menjadi 120 hari atau pada akhir bulan keempat setelah tahun buku berakhir sebagaimana dijelaskan dalam Peraturan Jasa Otoritas Keuangan Nomor 29/POJK.04/2016.

Oleh karena itu laporan keuangan harus disajikan tepat waktu dan disertai laporan auditan, untuk menghasilkan laporan keuangan yang relevan. Apabila perusahaan tidak menyampaikan laporan keuangan secara tepat waktu maka akan dikenakan sanksi administratif. Sanksi administratif yang dikenakan pada perusahaan berupa denda, yang sesuai dengan ketentuan pasal 63e peraturan pemerintah nomor 45 tahun 1995 tentang penyelenggaraan kegiatan di bidang pasar modal yang menyatakan emiten yang pernyataan pendaftarannya telah menjadi efektif, dikenakan sanksi denda Rp. 1.000.000 (satu juta rupiah) atas setiap hari keterlambatan penyampaian laporan dengan ketentuan jumlah keseluruhan denda paling banyak Rp. 500.000.000 (lima ratus juta rupiah). Jika batas waktu penyampaian Laporan Tahunan jatuh pada hari libur maka Laporan Tahunan wajib disampaikan paling lambat pada 1 (satu) hari kerja berikutnya. Informasi yang disajikan akan sangat berkontribusi pada perusahaan, dan akan lebih berguna jika perusahaan melaporkan nilai nilai perusahaan secara up-to-date. Ketepatan waktu adalah sebuah konsep lama akuntansi yang menekankan penyajian informasi perusahaan sebagai pengambilan keputusan.

\section{Kondisi Keuangan Perusahaan}

Kondisi Keuangan perusahaan merupakan cerminan dari kinerja keuangan dan tingkat kesehatan perusahaan. Dengan kinerja perusahaan yang baik maka akan menimbulkan kondisi keuangan yang baik. Laporan keuangan yang baik akan dapat menarik investor untuk menanamkan modal perusahaan dan auditor tidak mengeluarkan opini audit going concern pada perusahaan yang memiliki kondisi keuangan yang baik (Ramadhany, 2004:7). Semakin baik kondisi keuangan perusahaan semakin kecil kemungkinan auditor memberikan opini audit going concern dan auditor tidak pernah mengeluarkan opini going concern pada perusahaan yang kondisi keuangannya baik atau tidak mengalami finansial distress. Prediksi finansial distress (kebangkrutan) menggunakan model Revised Altman's Z-score, dimana revisi dari model sebelumnya yang dilakukan Altman.

Model yang dikembangkan oleh edward I. Altman tahun 1968 mengalami suatu revisi pada tahun 1983. Model ini mampu untuk memprediksi financial distress dan kepailitan dengan tingkat ketepatan 95\% sebelum financial distress dan kepailitan terjadi. Revisi yang dilakukan Altman merupakan penyesuaian yang dilakukan agar model prediksi kebangkrutan ini tidak hanya diaplikasikan untuk perusahaan go public, melainkan juga dapat diaplikasikan untuk perusahaanperusahaan yang tidak go public. Persamaan baru yang diperoleh sebagai berikut (Edward I Altman, 1983:106)

$$
Z=0,717 Z_{1}+0,874 Z_{2}+3,107 Z_{3}+0.420 Z_{4}+0,988 Z_{5}
$$

Keterangan :

$\mathrm{Z}_{1}=$ Working capital $/$ total assets

$\mathrm{Z}_{2}=$ retained earnings / total assets

$\mathrm{Z}_{3}=$ earning before interest and taxes / total assets

$\mathrm{Z}_{4}=$ book value of equity / book value of debt 


\section{$\mathrm{Z}_{5}=$ sales $/$ total assets}

Dari hasil perhitungan Model Altman Revisi diperoleh nilai Z-score yang dibagi dalam tiga kategori sebagai berikut :

1. Jika nilai $Z^{\prime}>2,90$ maka perusahaan sehat tidak termasuk pailit

2. Jika nilai $1,23 \leq Z^{\prime} \leq 2,90$ maka perusahaan termasuk dalam kategori grey area (tidak dapat ditentukan apakah perusahaan mengalami kepailitan atau tidak).

3. Jika nilai Z' $<1,23$ maka perusahaan termasuk dalam kategori pailit.

\section{Opini Audit Tahun Sebelumnya}

Opini audit tahun sebelumnya adalah opini audit yang diterima perusahaan pada tahun sebelumnya atau satu tahun sebelum penelitian. Opini audit tahun sebelumnya . Penerbitan Opini audit going concern tidak terlepas dari opini audit tahun sebelumnya karena kegagalan usaha pada suatu perusahaan untuk tahun tertentu tidak terlepas dari keadaan yang terjadi di tahun sebelumnya. Setyarno, dkk (2006) menyatakan bahwa auditor dalam menerbitkan opini audit going concern yang diterima oleh auditee pada tahun sebelumnya.

Setyarno, dkk (2006), menguji pengaruh ketersediaan informasi publik terhadap prediksi opini audit going concern ,dengan menggunakan discriminant analysis yang memasukan tipe Opini Audit tahun sebelumnya mempunyai akurasi prediksi paling tinggi, yaitu 89,9\%. Apabila tahun sebelumnya perusahaan mendapat Opini Audit Going concern, maka tahun berikutnya kemungkinan auditor memberi Opini Audit Going concern akan lebih besar.

\section{Opini Audit Going Concern}

Opini audit going concern adalah opini yang dikeluarkan oleh auditor untuk mengevaluasi apakah ada kesangsian tentang kemampuan perusahaan untuk mempertahankan kelangsungan hidupnya (IAI,2011 : SA Seksi 341).

Auditor bertanggung jawab untuk mengevaluasi apakah terdapat kesangsian besar terhadap kemampuan entitas dalam mempertahankan kelangsungan hidupnya dalam periode waktu pantas, tidak lebih dari satu tahun sejak tanggal laporan keuangan yang sedang diaudit. Evaluasi auditor berdasarkan atas pengetahuan tentang kondisi dan peristiwa yang ada pada atau yang telah terjadi sebelum pekerjaan lapangan selesai.

Dalam PSA Seksi 341.3 paragraf 6 ada faktor faktor yang yang mempengaruhi auditor dalam menerbitkan opini audit going concern :

1. Trend negatif, Sebagai contoh kerugian operasi yang berulang kali terjadi, kekurangan modal kerja, arus kas negatif dari kegiatan usaha, ratio keuangan penting yang jelek.

2. Petunjuk lain tentang kemungkinan kesulitan keuangan, sebagai contoh kegagalan dalam memenuhi kewajiban utangnya atau perjanjian serupa, penunggakan pembayaran divide, penolakan oleh pemasok terhadap pengajuan permintaan pembelian kredit biasa, rektrukturisasi utang, kebutuhan untuk mencari sumber atau metode pendanaan baru, atau penjualan sebagian besar aktiva.

3. Masalah intern - sebagai contoh, pemogokan kerja atau kesulitan hubungan perburuhan yang lain, ketergantungan besar atas sukses projek tertentu, komitmen jangka panjang yang tidak bersifat ekonomis, kebutuhan untuk secara signifikan memperbaiki operasi. 
4. Masalah luar yang telah terjadi - sebagai contoh, pengaduan gugatan pengadilan, keluarnya undang-undang, atau masalah-masalah lain yang kemungkinan membahayakan kemampuan entitas untuk beroperasi; kehilangan franchise, lisensi atau paten penting; kehilangan pelanggan atau pemasok utama; kerugian akibat bencana besar seperti gempa bumi, banjir, kekeringan, yang tidak diasuransikan atau diasuransikan namun dengan pertanggungan yang tidak memadai.

\section{METODE PENELITIAN}

\section{Desain Penelitian}

Penelitian ini merupakan penelitian kausal, yaitu penelitian yang mencari pengaruh antara satu atau lebih variable bebas (Independent Variable) terhadap variable terikat (Dependent Variable ).

\section{Jenis Data}

Penelitian ini menggunakan data kuantitatif dari data sekunder berupa laporan keuangan perusahaan manufaktur sektor aneka indsutri yang terdaftar di Bursa Efek Indonesia periode 2014-2018.

\section{Populasi dan Sampel Penelitian}

Populasi yang digunakan dalam penelitian ini adalah perusahaan manufaktur sektor aneka industri yang terdaftar di Bursa Efek Indonesia periode 2014-2018, dengan teknik pengambilan sampel terpilih (non probability sampling) yaitu menggunakan metode purposive sampling. Adapun kriteria pemilihan sampel yang ditentukan dalam penelitian ini adalah sebagai berikut :

1. Perusahaan manufaktur sektor aneka industri yang terdaftar di BEI berturutturut selama periode tahun 2014 sampai dengan tahun 2018.

2. Perusahaan yang menyajikan annual report lengkap secara keseluruhan untuk semua variabel penelitian dalam website perusahaan atau website BEI selama periode penelitian.

3. Perusahaan menerbitkan laporan keuangan perusahaan selama 5 tahun berturut - turut yaitu 2014 - 2018.

\section{Variabel Penelitian}

1. Variabel dependen (Y)

Variabel terikat yang digunakan dalam penelitian ini adalah penerimaan opini audit going concern.

2. Variabel independen (X)

Variabel bebas dalam penelitian ini adalah audit delay $\left(\mathrm{X}_{1}\right)$, kondisi keuangan $\left(\mathrm{X}_{2}\right)$, dan opini audit sebelumnya $\left(\mathrm{X}_{3}\right)$.

\section{Kerangka Pemikiran Teoritis}

Berdasarkan teori yang telah diuraikan sebelumnya maka dapat disusun kerangka pemikiran sebagai berikut : 


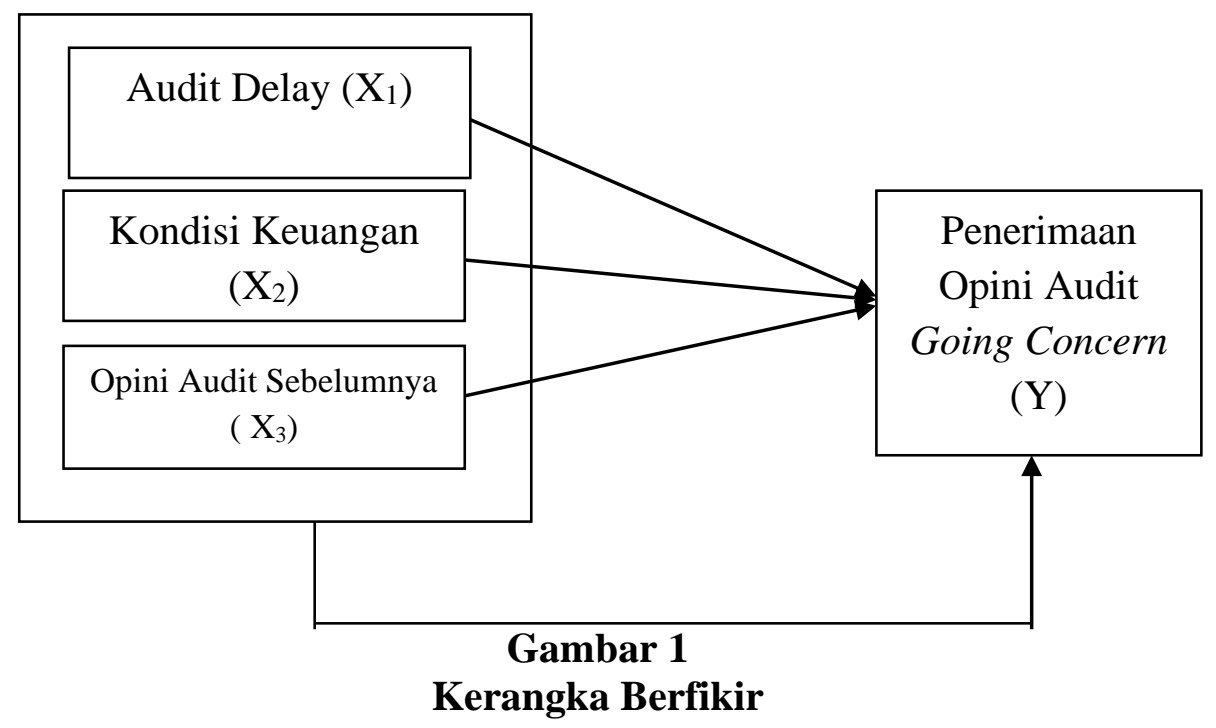

\section{Hipotesis}

$\mathrm{H}_{0} 1$ : Audit delay tidak berpengaruh terhadap penerimaan opini audit going concern.

$\mathrm{H}_{\mathrm{a}} 1$ : Audit delay berpengaruh terhadap penerimaan opini audit going concern.

$\mathrm{H}_{0} 2$ : Kondisi keuangan tidak berpengaruh terhadap penerimaan opini audit going concern.

$\mathrm{H}_{\mathrm{a}} 2$ : Kondisi keuangan berpengaruh terhadap penerimaan opini audit going concern.

$\mathrm{H}_{0} 3$ : Opini audit sebelumnya tidak berpengaruh terhadap penerimaan audit going concern.

$\mathrm{H}_{\mathrm{a}} 3$ : Opini audit sebelumnya berpengaruh terhadap penerimaan opini audit going concern.

$\mathrm{H}_{0} 4$ : Audit Delay, kondisi keuangan, opini audit sebelumnya tidak berpengaruh terhadap penerimaan opini audit going concern.

$\mathrm{H}_{\mathrm{a}} 4$ : Audit delay, kondisi keuangan, opini audit sebelumnya berpengaruh terhadap penerimaan opini audit going concern.

\section{ANALISIS HASIL DAN PEMBAHASAN}

Proses Seleksi sampel berdasarkan kriteria yang telah ditetapkan tampak pada tabel sebagai berikut :

\section{Tabel 1}

Proses Seleksi Sampel

\begin{tabular}{|c|c|c|c|}
\hline No & Kriteria Pemilihan Sampel & $\begin{array}{c}\text { Pelanggaran } \\
\text { Kriteria }\end{array}$ & Akumulasi \\
\hline 1 & $\begin{array}{c}\text { Perusahaan Manufaktur Sektor Aneka } \\
\text { Industri yang terdaftar di BEI Tahun }\end{array}$ & 0 & 44 \\
\hline
\end{tabular}




\begin{tabular}{|c|c|c|c|}
\hline & 2014-2018 dan tidak delisting & & \\
\hline 2 & $\begin{array}{c}\text { Menyajikan Annual Report Lengkap } \\
\text { dalam Website BEI pada Masa Periode } \\
\text { Penelitian }\end{array}$ & 9 & 35 \\
\hline 3 & $\begin{array}{c}\text { Menerbitkan Laporan Keuangan } \\
\text { Perusahaan selama } 5 \text { tahun berturut-turut }\end{array}$ & 0 & 35 \\
\hline & Jumlah Perusahaan Sampel & & 35 \\
\hline & Jumlah Tahun Pengamatan & & 5 \\
\hline & $\begin{array}{l}\text { tal Sampel Selama Periode Penelitian } \\
\text { 2014-2018 }\end{array}$ & & 175 \\
\hline
\end{tabular}

\section{Statistik Deskriptif}

\begin{tabular}{|c|c|c|c|c|c|}
\hline \multicolumn{6}{|c|}{$\begin{array}{c}\text { Statistik Deskriptif } \\
\text { Descriptive Statistics }\end{array}$} \\
\hline & $\mathrm{N}$ & Minimum & Maximum & Mean & Std. Deviation \\
\hline Y & 175 &, 00 & 1,00 &, 1314 & ,33884 \\
\hline $\mathrm{X} 1$ & 175 & 45,00 & 191,00 & 83,5314 & 16,57646 \\
\hline $\mathrm{X} 2$ & 175 & $-959,00$ & 827,00 & 88,7678 & 225,74607 \\
\hline X3 & 175 &, 00 & 1,00 &, 1029 & ,30464 \\
\hline Valid N (listwise) & 175 & & & & \\
\hline
\end{tabular}

Sumber : Data Olah SPSS, 2020

Berdasarkan tabel diatas, hasil analisis dengan menggunakan statistik deskriptif dijelaskan sebagai berikut :

1. Hasil analisis statistik deskriptif terhadap opini audit going concern menunjukkan nilai minimum sebesar 0 , nilai maksimum 1,00 sebesar dengan rata-rata sebesar 0,131 dan standar deviasi sebesar 0,338. Nilai rata-rata sebesar 0,131 menunjukkan bahwa sampel penelitian yang menerima opini audit going concern pada tahun berjalan lebih sedikit yaitu 23 sampel dan sampel penelitian yang menerima opini non going concern pada tahun berjalan yaitu 152 sampel.

2. Hasil analisis statistik deskriptif terhadap audit delay menunjukkan nilai minimum sebesar 45,00, nilai maksimum sebesar 191,0 dengan rata-rata sebesar 83,531 dan standar deviasi sebesar 16,576. Nilai rata-rata sebesar 83,53 menunjukkan bahwa perusahaan sampel penelitian rata-rata mengungkapkan laporan keuangannya pada 83 hari dari laporan tutup buku perusahaan.

3. Hasil analisis statistik deskriptif terhadap kondisi keuangan menunjukkan nilai minimum sebesar $-959,00$, nilai maksimum sebesar 827,00 dengan rata-rata sebesar 88,767 dan standar deviasi sebesar 225,74. Nilai rata-rata sebesar 88,767 menunjukkan bahwa perusahaan sampel penelitian termasuk dalam kategori perusahaan dengan kondisi keuangan berkriteria daerah rawan bangkrut (grey area).

4. Hasil analisis statistik deskriptif terhadap opini audit sebelumnya menunjukkan nilai minimum sebesar 0 , nilai maksimum sebesar 1,00 dengan rata-rata 
sebesar 0,102 dan standar deviasi sebesar 0,304. Nilai rata-rata sebesar 0,102 menunjukkan bahwa perusahaan sampel penelitian yang mendapatkan opini going concern pada tahun sebelumnya lebih sedikit yaitu 18 sampel dan perusahaan yang mendapatkan opini non going concern pada tahun sebelumnya sebanyak 157 sampel.

\section{Uji Hipotesis}

\section{Menguji Kelayakan Model Regresi}

Analisis selanjutnya yaitu dengan menilai kelayakan model regresi logistik. Pengujian kelayakan model regresi logistic dinilai dengan menggunakan Hosmer and Lemeshow's Goodness of Fit Test Goodness yang diukur dengan nilai Chisquare. Hipotesis yang digunakan untuk menilai kelayakan model regresi ini adalah :

$\mathrm{H}_{\mathrm{o}}$ : Tidak ada perbedaan antara model dengan data

$\mathrm{H}_{\mathrm{a}}$ : Ada perbedaan model dengan data

Berikut hasil pengujian kelayakan model regresi logistik :

\section{Tabel 3}

Kelayakan Model Regresi Logistik.
Hosmer and Lemeshow Test
\begin{tabular}{|l|c|c|r} 
Step & Chi-square & df & Sig. \\
\hline 1 & 3,441 & 8 &, 904 \\
\hline Sumber : Data Olah SPSS, 2020
\end{tabular}

Dalam tabel diatas menunjukkan hasil pengujian Hosmer and Lemeshow's Test. Berdasarkan tabel tersebut menunjukkan nilai signifikasinya sebesar 0,904 yang nilainya lebih besar dari 0,05 . Nilai signifikansi yang diperoleh tersebut diatas 0,05 yang berarti hipotesis $0\left(\mathrm{H}_{0}\right)$ diterima. Dengan demikian dapat disimpulkan bahwa model mampu memprediksi nilai observasinya atau dapat dikatakan model dapat diterima karena cocok dengan data observasinya.

\section{Menilai Keseluruhan Model (Overall Model Fit)}

Pengujian overall model fit dilakukan dengan membandingkan nilai antara $2 \log$ Likelihood (-2LogL) pada awal (Block Number $=0)$ dengan nilai $-2 \log$ Likelihood $(-2 \operatorname{LogL})$ pada akhir (Block Number $=1$ ).

Tabel Iteration History 0 yang merupakan -2 Log Likelihood awal. Tabel ini akan dibandingkan dengan tabel Iteration history 1 yang merupakan -2Log Likelihood akhir. Adanya selisih antara -2Log Likelihood awal dengan -2Log Likelihood akhir akan menunjukkan bahwa model fit dengan data.

\section{Tabel 4}

Overall model fit $($ Blok $0=$ Beginning Block $)$

$$
\text { Iteration History }{ }^{\mathrm{a}, \mathrm{b}, \mathrm{c}}
$$

\begin{tabular}{|c|c|c|c|}
\hline \multicolumn{2}{|c|}{ Iteration } & -2 Log likelihood & $\begin{array}{c}\text { Coefficients } \\
\text { Constant }\end{array}$ \\
\hline \multirow[t]{3}{*}{ Step 0} & 1 & 139,971 & $-1,474$ \\
\hline & 2 & 136,238 & $-1,836$ \\
\hline & 3 & 136,183 & $-1,887$ \\
\hline
\end{tabular}

Jurnal Ilmiah Akuntansi dan Ekonomi Volume. 5 Nomor. 2, Agustus 2020 Hal. 10 


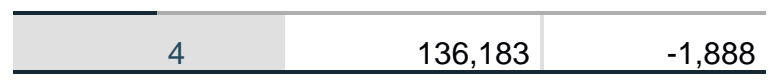

a. Constant is included in the model.

b. Initial -2 Log Likelihood: 136,183

c. Estimation terminated at iteration number 4

because parameter estimates changed by less than , 001 .

Sumber : Data Olah SPSS, 2020

Berdasarkan hasil pengolahan SPSS pada tabel diatas menunjukkan bahwa nilai -2LogLikelihood awal (Tabel literation History 0) adalah sebesar 136,183. Langkah selanjutnya pengujian overall model fit dengan memasukkan variabel bebas pada penelitian (audit delay, kondisi keuangan, dan opini audit sebelumnya).

\section{Tabel 5}

Overall model fit (Blok $1:$ Method = Enter)

Iteration History ${ }^{\mathrm{a}, \mathrm{b}, \mathrm{c}, \mathrm{d}}$

\begin{tabular}{|c|c|c|c|c|c|c|}
\hline \multirow[b]{2}{*}{ Iteration } & & \multirow[b]{2}{*}{-2 Log likelihood } & \multicolumn{4}{|c|}{ Coefficients } \\
\hline & & & Constant & $\mathrm{X} 1$ & $\mathrm{X} 2$ & X3 \\
\hline \multirow[t]{7}{*}{ Step 1} & 1 & 82,389 & $-1,966$ & ,003 &,- 001 & 3,136 \\
\hline & 2 & 63,601 & $-3,127$ & ,009 &,- 003 & 4,107 \\
\hline & 3 & 59,525 & $-4,334$ & ,018 &,- 004 & 4,541 \\
\hline & 4 & 59,119 & $-5,057$ & ,025 &,- 004 & 4,743 \\
\hline & 5 & 59,112 & $-5,174$ & ,026 &,- 005 & 4,778 \\
\hline & 6 & 59,112 & $-5,176$ & ,026 &,- 005 & 4,779 \\
\hline & 7 & 59,112 & $-5,176$ &, 026 &,- 005 & 4,779 \\
\hline
\end{tabular}

a. Method: Enter

b. Constant is included in the model.

c. Initial -2 Log Likelihood: 136,183

d. Estimation terminated at iteration number 7 because parameter estimates changed by less than ,001.

Sumber: Data Olah SPSS, 2020

Dari data tabel diatas diketahui bahwa nilai -2LogLikelihood awal adalah 136,183 dan nilai -2LogLikelihood akhir pada tabel diatas dihasilkan 59,112 sehingga terjadi penurunan nilai sebesar 77,071. Berdasarkan output tersebut menunjukkan adanya penurunan nilai -2LogLikelihood dapat diartikan bahwa penambahan variabel bebas ke dalam model dapat memperbaiki model fit serta menunjukkan model regresi yang lebih baik atau dengan kata lain model yang dihipotesiskan fit dengan data.

\section{Pengujian Secara Parsial}

Analisis ini bertujuan untuk mengetahui ada atau tidaknya hubungan atau pengaruh antara variabel bebas yaitu audit delay, kondisi keuangan, dan opini audit 
sebelumnya terhadap penerimaan opini audit going concern. Berikut adalah hasil dari regresi logistik.

\section{Tabel 6}

Hasil Uji Regresi Logistik

\begin{tabular}{|c|c|c|c|c|c|c|c|c|c|}
\hline \multicolumn{10}{|c|}{ Variables in the Equation } \\
\hline & & \multirow[b]{2}{*}{ B } & \multirow[b]{2}{*}{ S.E. } & \multirow[b]{2}{*}{ Wald } & \multirow[b]{2}{*}{$\mathrm{df}$} & \multirow[b]{2}{*}{ Sig. } & \multirow[b]{2}{*}{$\operatorname{Exp}(B)$} & \multicolumn{2}{|c|}{$\begin{array}{c}\text { 95\% C.I.for } \\
\operatorname{EXP(B)}\end{array}$} \\
\hline & & & & & & & & Lower & Upper \\
\hline \multirow[t]{4}{*}{ Step $1^{a}$} & $\mathrm{X} 1$ & 026 & 023 & 1,211 & 1 & ,271 & 1,026 & ,980 & 1,074 \\
\hline & $\mathrm{x} 2$ &,- 005 & ,001 & 9,043 & 1 & ,003 & ,996 & ,993 & ,998 \\
\hline & $\mathrm{X} 3$ & 4,779 & ,879 & 29,544 & 1 &, 000 & 118,953 & 21,233 & 666,404 \\
\hline & $\begin{array}{l}\text { Const } \\
\text { ant }\end{array}$ & $-5,176$ & 2,085 & 6,164 & 1 &, 013 & ,006 & & \\
\hline
\end{tabular}

a. Variable(s) entered on step 1: X1, X2, X3.

Sumber : Data Olah SPSS

Tabel diatas menunjukkan hasil pengujian regresi logistik pada taraf kesalahan 5\%. Hasil pengujian regresi logistik menghasilkan model sebagai berikut

$$
\begin{aligned}
& \mathbf{Y}=\mathbf{- 5 , 1 7 6}+\mathbf{0 , 0 2 6} \mathbf{X}_{\mathbf{1}}-\mathbf{0 , 0 0 5} \mathbf{X}_{\mathbf{2}}+\mathbf{4 , 7 7 9} \mathbf{X}_{\mathbf{3}}+\boldsymbol{\varepsilon} \\
& \text { Dimana : } \\
& \mathrm{Y} \quad=\text { Penerimaan Opini Audit Going Concern } \\
& \mathrm{X}_{1} \quad=\text { Audit Delay } \\
& \mathrm{X}_{2} \quad=\text { Kondisi Keuangan } \\
& \mathrm{X}_{3} \quad=\text { Opini Audit Sebelumnya } \\
& \mathcal{E} \quad=\text { Error. }
\end{aligned}
$$

Variabel Konstanta pada model regresi logistik ini mempunyai nilai negatif yaitu sebesar 5,176 yang berarti tanpa adanya variabel lain maka penerimaan opini audit going concern bernilai sebesar 5,176 satuan.

Variabel audit delay memiliki statistik wald sebesar 1,211 sedangkan berdasarkan tabel Chi-Square dengan tingkat signifikansi 0,05 dan tingkat kebebasan sebesar 1 diperoleh hasil 3,441. Nilai koefisien variabel ini sebesar 0,026 yang berarti setiap kenaikan $1 \%$ pada audit delay akan mengalami kenaikan penerimaan opini audit going concern sebesar 0,026 satuan dengan asumsi variabel lain tetap. Nilai signifikansi audit delay menghasilkan nilai yang lebih besar dari 0,05 yaitu memiliki nilai sebesar 0,271. Dengan demikian hipotesis Hal ditolak. Hasil ini menyatakan bahwa audit delay tidak berpengaruh signifikan terhadap penerimaan opini audit going concern.

Variabel kondisi keuangan memiliki statistik wald sebesar 9,043 sedangkan berdasarkan tabel Chi-Square dengan tingkat signifikansi 0,05 dan tingkat kebebasan sebesar 1 diperoleh hasil 3,441. Nilai koefisien variabel ini sebesar 0,005 yang berarti setiap kenaikan $1 \%$ pada kondisi keuangan akan mengalami penurunan penerimaan opini audit going concern sebesar 0,005 satuan dengan asumsi variabel lain tetap. Nilai signifikansi kondisi keuangan menghasilkan nilai yang lebih kecil dari 0,05 yaitu memiliki nilai sebesar 0,003. Dengan demikian 
hipotesis Ha2 diterima. Hasil ini menyatakan bahwa kondisi keuangan berpengaruh signifikan terhadap penerimaan opini audit going concern.

Variabel opini audit sebelumnya memiliki statistik wald sebesar 29,544 sedangkan berdasarkan tabel Chi-Square dengan tingkat signifikansi 0,05 dan tingkat kebebasan sebesar 1 diperoleh hasil 3,441. Nilai koefisien variabel ini sebesar 4,779 yang berarti setiap kenaikan $1 \%$ pada opini audit sebelumnya akan mengalami kenaikan penerimaan opini audit going concern sebesar 4,779 satuan dengan asumsi variabel lain tetap. Nilai signifikansi opini audit sebelumnya menghasilkan nilai yang lebih kecil dari 0,05 yaitu memiliki nilai sebesar 0,000. Dengan demikian hipotesis Ha3 diterima. Hasil ini menyatakan bahwa opini audit sebelumnya berpengaruh signifikan terhadap penerimaan opini audit going concern.

\section{Uji Omnimbus ( Overall test)}

Uji ini dilakukan untuk mengetahui apakah secara bersama-sama variabel independen berpengaruh signifikan terhadap variabel dependen.

\section{Tabel 7}

Omnibus Tests of Model Coefficients

\begin{tabular}{llr|r|r} 
& & Chi-square & df & \multicolumn{1}{c}{ Sig. } \\
\hline \multirow{2}{*}{ Step 1 } & Step & 77,070 & 3 &, 000 \\
\cline { 2 - 6 } & Block & 77,070 & 3 &, 000 \\
\cline { 2 - 6 } & Model & 77,070 & 3 &, 000 \\
\hline
\end{tabular}

Berdasarkan tabel diatas menunjukkan bahwa secara simultan audit delay, kondisi keuangan, dan opini audit sebelumnya dapat menjelaskan mengenai penerimaan opini audit going concern. Hal ini dilihat dari hasil Chi Square sebesar 77,070 dengan df sebesar 3 dan signifikansi sebesar 0,000 yang nilainya lebih kecil dari 0,05 atau nilai Chi Square hitung 77,070 lebih besar dari Chi Square tabel 7,814. Hal ini menunjukkan bahwa hipotesis $\mathrm{Ha} 4$ diterima, sehingga dapat disimpulkan audit delay, kondisi keuangan, dan opini audit sebelumnya berpengaruh secara simultan terhadap penerimaan opini audit going concern.

\section{Koefisien Determinasi}

Besarnya nilai koefisien determinasi pada model regresi logistik ditunjukkan dengan nilai Nagelkerke R Square.

\section{Tabel 8}

Koefisien Determinasi

Model Summary

\begin{tabular}{rr|r|r} 
Step & -2 Log likelihood & \multicolumn{1}{c}{$\begin{array}{c}\text { Cox \& Snell R } \\
\text { Square }\end{array}$} & \multicolumn{2}{c}{$\begin{array}{c}\text { Nagelkerke R } \\
\text { Square }\end{array}$} \\
\hline 1 & $59,112^{\mathrm{a}}$ &, 356 &, 659 \\
\hline
\end{tabular}

a. Estimation terminated at iteration number 7 because parameter estimates changed by less than ,001.

Sumber: Data Olah SPSS

Berdasarkan hasil output SPSS pada tabel 4. 9 diatas menunjukkan nilai Cox \& Snell R Square adalah sebesar 0,356 atau 35,6\% dan nilai nagelkerke $\mathrm{R}$ 
Square sebesar 0,659 atau 65,9\% yang berarti menunjukkan bahwa kemampuan seluruh variabel independen dalam menjelaskan variabel dependen secara bersamasama adalah sebesar 0,659 atau $65,9 \%$, sedangkan sisanya sebesar $34,1 \%$ dijelaskan faktor-faktor lain diluar penelitian ini.

\section{Pembahasan dan Interpretasi Penelitian}

Pengaruh Audit Delay $\left(\mathrm{X}_{1}\right)$ Terhadap Penerimaan Opini Audit Going concern (Y)

Variabel audit delay menunjukkan nilai koefisien 0,026 dengan nilai signifikansi sebesar 0,271. Nilai signifikan yang diperoleh lebih besar dari 0,05, maka hipotesis $\left(\mathrm{H}_{\mathrm{o}} 1\right)$ diterima dan hipotesis $\left(\mathrm{H}_{\mathrm{a}} 1\right)$ ditolak, sehingga dapat disimpulkan bahwa audit delay tidak berpengaruh terhadap penerimaan opini audit going concern.

Lamanya audit delay belum tentu mengindikasikan adanya masalah going concern pada perusahaan. Kemungkinan keterlambatan opini yang dikeluarkan bisa disebabkan karena auditor lebih banyak pengujian dan auditor berhati-hati dalam mengeluarkan opini audit going concern. Semakin lama audit delay maka auditor dapat menggali informasi lebih banyak lagi, sehingga kemungkinan besar auditor akan menemukan bukti yang cukup untuk menerbitkan opini audit going concern.

\section{Pengaruh Kondisi Keuangan $\left(\mathrm{X}_{2}\right)$ Terhadap Penerimaan Opini Audit Going concern (Y)}

Variabel Kondisi Keuangan menggunakan model prediksi kebangkrutan yang diproksikan dengan Z-score menunjukkan nilai koefisien -0,005 dengan nilai signifikansi sebesar 0,003. Nilai signifikan yang diperoleh lebih kecil dari 0,05 , maka hipotesis $\left(\mathrm{H}_{02}\right)$ ditolak dan hipotesis $\left(\mathrm{H}_{\mathrm{a} 2}\right)$ diterima, sehingga dapat disimpulkan bahwa kondisi keuangan berpengaruh signifikan terhadap opini audit going concern.

Jadi dapat disimpulkan jika seorang auditor biasanya memberikan opini audit going concern dengan melihat kondisi keuangan perusahaan yang tidak mengalami permasalahan keuangan secara terus -menerus akan mengakibatkan nilai rasio Z-score rendah sehingga akan berpeluang besar untuk menerima opini audit going concern. Berbeda dengan perusahaan yang mempunyai kondisi keuangan yang baik karena perusahaan yang mempunyai kondisi keuangan yang baik akan kecil memperoleh opini audit going concern.

Perusahaan yang mempunyai kondisi keuangan yang tidak sehat kemudian menerima opini audit going concern maka menurunkan harga saham dan keadaan seperti ini akan mempersulit perusahaan untuk mendapatkan investor, karena opini audit going concern merupakan peringatan dini pada kebangkrutan suatu perusahaan. Hal ini terjadi karena semakin baik kondisi keuangan perusahaan maka semakin kecil kemungkinan bagi auditor untuk memberikan opini audit going concern. Perusahaan yang tidak mempunyai permasalahan yang serius kemungkinan besar tidak akan menerima opini audit going concern.

\section{Pengaruh Opini Audit Sebelumnya $\left(\mathbf{X}_{3}\right)$ Terhadap Penerimaan Opini Audit Going concern (Y)}

Variabel opini audit sebelumnya menunjukkan nilai koefisien 4,779 dengan nilai signifikansi sebesar 0,000 . Nilai signifikan yang diperoleh lebih kecil dari 
0,05, maka hipotesis $\left(\mathrm{H}_{\mathrm{o}} 3\right)$ ditolak dan hipotesis $\left(\mathrm{H}_{\mathrm{a}} 3\right)$ diterima sehingga dapat disimpulkan bahwa opini audit sebelumnya berpengaruh signifikan terhadap opini audit going concern.

Opini audit tahun sebelumnya menjadi faktor yang menjadi pertimbangan auditor untuk mengeluarkan opini nya. Apabila tahun sebelumnya perusahaan mendapatkan opini going concern namun pada tahun berjalan kondisi perusahaan tidak semakin membaik maka kemungkinan besar auditor akan mengeluarkan opini going concern kembali.

\section{Pengaruh Audit delay $\left(X_{1}\right)$, Kondisi Keuangan $\left(X_{2}\right)$ dan Opini Audit Sebelumnya $\left(\mathrm{X}_{3}\right)$, terhadap Penerimaan Opini Audit Going concern (Y)}

Berdasarkan hasil Chi-Square sebesar 77,070 dengan df sebesar 3 dan nilai signifikansi sebesar 0,000 yang nilainya lebih kecil dari 0,05, hal ini menunjukkan bahwa hipotesis $\left(\mathrm{H}_{0} 4\right)$ ditolak dan hipotesis $\left(\mathrm{H}_{2} 4\right)$ diterima, sehingga dapat disimpulkan audit delay, kondisi keuangan dan opini audit sebelumnya berpengaruh secara simultan terhadap penerimaan opini audit going concern.

\section{KESIMPULANDAN SARAN}

\section{Kesimpulan}

1. Berdasarkan hasil uji regresi logistik menunjukkan bahwa audit delay secara statistik tidak berpengaruh signifikan terhadap penerimaan opini audit going concern selama 5 tahun pengamatan (2014-2018). Hal ini dibuktikan dengan nilai signifikansi sebesar 0,271 lebih besar dari $0,05(0,271>0,05)$ maka hipotesis $\left(\mathrm{H}_{\mathrm{o}} 1\right)$ diterima dan hipotesis $\left(\mathrm{H}_{\mathrm{a}} 1\right)$ ditolak.

2. Berdasarkan hasil uji regresi logistik menunjukkan bahwa kondisi keuangan secara statistik berpengaruh signifikan terhadap penerimaan opini audit going concern selama 5 tahun pengamatan (2014-2018). Hal ini dibuktikan dengan nilai signifikansi sebesar 0,003 lebih kecil dari $0,05(0,003<0,05)$ maka hipotesis $\left(\mathrm{H}_{\mathrm{o}} 2\right)$ ditolak dan hipotesis $\left(\mathrm{H}_{\mathrm{a}} 2\right)$ diterima.

3. Berdasarkan hasil uji regresi logistik menunjukkan bahwa opini audit sebelumnya secara statistik berpengaruh signifikan terhadap penerimaan opini audit going concern selama 5 tahun pengamatan (2014-2018). Hal ini dibuktikan dengan nilai signifikansi sebesar 0,000 lebih kecil dari 0,05 $(0,000$ $<0,05)$ maka hipotesis $\left(\mathrm{H}_{0} 4\right)$ ditolak dan hipotesis $\left(\mathrm{H}_{\mathrm{a}} 4\right)$ diterima.

4. Berdasarkan hasil uji regresi logistik menunjukkan bahwa audit delay, kondisi keuangan, dan opini audit sebelumnya secara simultan berpengaruh signifikan terhadap penerimaan opini audit going concern selama 5 tahun pengamatan (2014-2018). Hal ini dibuktikan dengan nilai dari Chi-Square sebesar 77,070 dengan df sebesar 3 dan signifikansi sebesar 0,000 yang nilainya lebih kecil dari $0,05(0,000<0,05)$ maka hipotesis $\left(\mathrm{H}_{0} 4\right)$ ditolak dan hipotesis $\left(\mathrm{H}_{\mathrm{a}} 4\right)$ diterima.

\section{Saran}

1. Penelitian ini hanya menggunakan perusahaan-perusahaan manufaktur sektor aneka industri yang terdaftar di Bursa Efek Indonesia (BEI), dan bagi penelitian selanjutnya dapat menggunakan semua industri manufaktur atau sektor lainnya selain manufaktur agar sampel yang digunakan lebih banyak. 
2. Menambah variabel independen lain seperti : audit tenure, reputasi KAP, ukuran klien, opinion shopping, dll yang mungkin dapat mempengaruhi penerimaan opini audit going concern.

\section{DAFTAR PUSTAKA}

Agoes, Sukrisno. 2012. "Auditing: Petunjuk Praktis Pemeriksaan Akuntan oleh Akuntan Publik". Jilid 1, Edisi 4, Jakarta: Salemba empat.

Alichia, Yashinta Putri. 2013. "Pengaruh Ukuran Perusahaan, Pertumbuhan Perusahaan, dan Opini Tahun Sebelumnya Terhadap Opini Audit Going concern". Jurnal Penelitian. Universitas Negeri Padang.

Arens, Alvin A. 2012. Auditing: Pendekatan Terpadu (Auditing An Integrated Approach), Jilid 1. Edisi 11. Jakarta: Salemba Empat.

Arens A. Alvin, Randal J. Elder dan Mark S. Beasley. 2015. Auditing dan Jasa Assurance Pendekatan Terintegrasi. Jilid I. Edisi Lima Belas.Jakarta. Erlangga

Anita Rahayu Ningsih.2014. Pengaruh Kondisi Keuangan, Disclosure, Reputasi Auditor, Dan Opini Audit Tahun Sebelumnya Pada Pengungkapan Opini Audit Going concern. Jurnal Akuntansi Dan Auditing Vol. 11/ No.1 / November 2014:25-37.

Badingatus Sholikah dan Kiswanto. 2010. Pengaruh Kondisi Keuangan, Pertumbuhan dan Opini Audit Tahun Sebelumnya terhadap Opini Audit Going concern. Jurnal Dinamika Akuntansi Vol 2. No 1, Maret 2010, 5664.

BAPEPAM. 2006. Keputusan Nomor: KEP-134/BL/2006 : Tentang Kewajiban Penyampaian Laporan Tahunan Bagi Emiten atau Perusahaan Publik. www.bapepam.go.id

Fauzan Syahputra dan M Rizal Yahya 2017. Pengaruh Audit Tenure, Audit Delay, Opini Audit Tahun Sebelumnya dan Opinion Shopping terhadap Penerimaan opini audit going concern Pada Perusahaan Manufaktur yang Terdaftar di Bursa Efek Indonesia. Jurnal Ilmiah Mahasiswa Ekonomi Akuntansi Vol 2, No 3, (2017) : 39-47

Ghozali, Imam.2016. Aplikasi Analisis Multivariate Dengan Program (IBM SPSS). Edisi 8. Badan Penerbit Universitas Diponegoro, Semarang.

Gita Mariana, M.Dwi Purbo Kuncoro, Ryando.2018.Pengaruh Debt Default, Disclosure level, dan Audit Lag terhadap Opini Audit Going concern. Seminar Nasional Cendekiawan ke 4 Tahun 2018.

Ikatan Akuntan Indonesia. 2011. Standar Profesional Akuntan Publik. Jakarta. Salemba Empat.

Irfana, Muhammad Jauhan. 2012. Analisis Pengaruh Debt Default, Kualitas Audit, Opinion Shopping dan Kepemilikan Perusahaan terhadap Penerimaan Opini Going concern. Skripsi. Program Sarjana Universitas Diponegoro Semarang.

Junaidi dan Jogiyanto Hartono. 2010. Faktor Non Keuangan Pada Opini Going concern. Simposium Nasional Akuntansi XIII Purwokerto.

Lingga Fitriani dan Dharma Tintri Ediraras Sudarsono. 2007. Disclosure Index Laporan Tahunan Emiten di BEJ. Proceeding PESAT (Psikologi, 
Ekonomi, Sastra, Arsitek \& Sipil). Auditorium Kampus Gunadarma,Vol.2 ISSN: 1858-2559, 21-22 Agustus 2007.

Mariani. 2015. Pengaruh Audit Client Tenure, Audit Delay, Opinion Shopping, dan Proporsi Komisaris Independen terhadap Penerimaan Opini Audit Going concern pada Perusahan Real Estate and Property yang terdaftar di BEI tahun 2007-2012. Faculty of Economics Riau Univeristy.

Menon, K., and K.B. Schawartz, "The Auditor's Report for Companies Facing Bankruptcy." The Journal of Commercial Bank Lending, January 1986,p.42-52.

Mirna Dyah Pratitorini dan Indira Januarti.2011. Analisis Pengaruh Kualiatas Audit, Debt Defaul, Dan Opinion Shopping Terhadap Penerimaan Opini Going concern. Jurnal Akuntansi Dan Keuangan Indonesia. Volume 8 No. 1 Juni 2011.

Mulyadi. 2014. Auditing. Edisi keenam. Jakarta: Salemba Empat.

Noviliana, Maria V. Irene, dan Evelyn Setiawan.2012. Pengaruh Kondisi Keuangan, Reputasi Auditor, Disclosure, Dan Corporate Governance Terhadap Penerimaan Opini Audit Going concern.

Oktaviani Rizqi Khusnul Khotimah. 2015. Pengaruh Kualitas Audit, Kondisi Keuangan Perusahaan, Opini Audit Tahun Sebelumnya Dan Pertumbuhan Perusahaan Terhadap Opini Audit Going concern. Universitas Muhammadiyah Surakarta, Surakarta.

Panjaitan, Bastian. 2010. "Analisis Pengaruh Total Aktiva, Jenis Opini Auditor, Ukuran KAP, dan Rasio Profitabilitas Terhadap Audit Delay". Fakultas Ekonomi Universitas Indonesia.

PSAP 01 (150.1-150.2 2011).

Puji Lestari.2017. Pengaruh Financial Distress, Disclosure, dan Opini Audit Tahun Sebelumnya Terhadap Opini Audit Going concern. PROFITA. Volume 10.No.3.Desember.3.2017

Ramadhany, Alexander. 2004. Analisis faktor-faktor yang mempengaruhi penerimaan Penerimaan Opini Going concern pada Perusahaan Manufaktur yang mengalami Financial Distress di Bursa Efek Jakarta. Jurnal MAKSI, 4:146-160.

Rachmawaty, Sistya. 2008. Pengaruh Faktor Internal dan Eksternal Perusahaan terhadap Audit Delay dan Timeliness. Jurnal Akuntansi dan Keuangan. Vol.10, No. 1:1-10. 


\title{
ANALISIS FAKTOR-FAKTOR YANG MEMPENGARUHI PENERAPAN TRANSFER PRICING PADA PERUSAHAAN MANUFAKTUR YANG TERDAFTAR DI BURSA EFEK INDONESIA TAHUN 2016-2019
}

\author{
Nia Tresnawaty, SE., M.Ak \\ niatresna@yahoo.com \\ Fakultas Ekonomi dan Bisnis - Program Studi Akuntansi \\ Universitas Satya Negara Indonesia
}

\begin{abstract}
ABSTRAK
Tujuan penelitian ini adalah untuk mengetahui faktor-faktor yang mempengaruhi penerapan transfer pricing. Populasi dalam penelitian ini adalah perusahaan Manufaktur yang terdaftar di Bursa Efek Indonesia pada tahun 2016-2019.

Penelitian ini menggunakan data sekunder yang berasal dari laporan keungan Bursa Efek Indonesia dan Website Perusahaan. Perusahaan Sampel ditentukan dengan metode purposive sampling sehingga diperoleh 260 data yang dijadikan sampel. Analisis data menggunakan metode analisis regressi logistik dengan bantuan sistem SPSS versi 23.

Hasil penelitian menunjukan secara parsial, beban pajak dan tunneling incentive berpengaruh terhadap penerapan transfer pricing sedangkan mekanisme bonus tidak berpengaruh. Dan Secara simultan beban pajak, tunneling incentive dan mekanisme bonus berpengaruh terhadap penerapan transfer pricing.
\end{abstract}

Kata Kunci : Beban Pajak, Tunneling Incentive, Mekanisme Bonus dan Transfer Pricing 


\section{PENDAHULUAN}

\section{Latar Belakang}

Menghadapi era globalisasi yang saat ini semakin modern, menyebabkan perekonomian berkembang tanpa batas membuat batas-batas negara menjadi hampir tidak ada, bahkan negara sudah bukan menjadi batasan. Masalah-masalah baru bermunculan. Salah satunya yakni pada perusahaan multinasional yang akan menghadapi masalah perbedaan pajak yang berlaku di setiap negara.

Perbedaan tarif pajak ini membuat perusahaan multinasional mengambil keputusan untuk melakukan transfer pricing. Dengan penerapan transfer pricing ini menimbulkan permasalahan yang sampai saat ini sering terjadi, diantaranya masalah pajak, ketentuan anti-dumping, bea cukai, persaingan usaha yang tidak sehat, dan masalah internal manajemen, serta masih banyak masalah lain yang berhubungan dengan adanya transfer pricing. Di Indonesia transfer pricing diatur dalam Pasal 18 Undang- Undang Nomor 36 Tahun 2008 tentang pajak penghasilan. Peraturan tersebut memuat beberapa hal, yaitu pengertian hubungan istimewa, wewenang menentukan perbandingan utang dan modal, dan wewenang untuk melakukan koreksi dalam transaksi yang tidak wajar. Adanya hubungan istimewa dapat mengakibatkan ketidakwajaran harga, biaya, atau imbalan lain yang direalisasikan dalam suatu transaksi usaha.

Tujuan awal transfer pricing yaitu sebagai penilaian kinerja antar anggota serta divisi perusahaan. Namun, perkembangan zaman telah mampu mengubah fungsi awal transfer pricing tersebut. Praktik transfer pricing juga sering digunakan untuk melakukan menajemen pajak yaitu sebuah usaha dimana perusahaan meminimalkan jumlah pajak yang harus dibayar. karena pajak mempunyai sifat memaksa dan memang merupakan salah satu hal yang perlu diminimalisir hingga dihindari oleh banyak perusahaan (Mangoting, 2004). Beberapa peneliti telah mencoba meneliti tentang hubungan pajak pada transfer pricing, diantaranya oleh Yuniasih dkk. (2012), Hartati dkk. (2015), dan Noviastika dkk. (2016) yang menemukan bahwa pajak berpengaruh terhadap keputusan transfer pricing. Namun hasil penelitian dari Marfuah (2014) menunjukkan hal yang berbeda, yaitu tidak adanya pengaruh antara pajak terhadap keputusan perusahaan dalam melakukan transfer pricing.

Keputusan Transfer pricing juga dipengaruhi oleh tunneling. Gilson dan Gordon (2003) menyatakan ada beberapa langkah yang bisa ditempuh majority shareholder untuk memperoleh keuntungan pribadi melalui kontrol kebijakan operasi perusahaan seperti deviden, bonus, gaji, dan tunjangan dan langkah untuk mendapat keuntungan pribadi melalui kebijakan kontraktual antara lain dengan tunneling. Bisa dikatakan bahwa perusahaan akan melakukan hal yang membuat biaya pajak kecil. Tunneling adalah tindakan majority shareholder yang mengalihkan aset dan profit perusahaan untuk memperoleh manfaat privat, namun bebannya juga ikut ditanggung oleh minority shareholder. Kegiatan tunneling berhubungan erat dengan kepemilikan saham pada perusahan tersebut (Mutamimah, 2009). Penelitian tentang tunneling incentive telah dilakukan oleh Yuniasih, Rasmini dan Wirakusuma (2012), yang menemukan tunneling incentive berpengaruh positif pada keputusan perusahaan manufaktur dalam melakukan transfer pricing. Namun penelitian yang dilakukan oleh Melani (2016) memperoleh

Jurnal Ilmiah Akuntansi dan Ekonomi Volume. 5 Nomor. 2, Agustus 2020 Hal. 19 
hasil bahwa Tunneling Incentive tidak berpengaruh terhadap keputusan melakukan transfer pricing.

Selain pajak dan tunneling incentive ada juga mekanisme bonus, berdasarkan penelitian Refgia (2017) mengemukakan bahwa mekanisme bonus adalah kompensasi tambahan atau penghargaan yang diberikan kepada pegawai atas keberhasilan pencapaian tujuan-tujuan yang di targetkan oleh perusahaan. Mekanisme bonus berdasarkan besarnya laba akan membuat direksi berupaya untuk melakukan manipulasi laba bahkan juga dilakukan manipulasi laba bersih dengan tujuan mampu memaksimalkan bonus diterimanya. Penelitian mengenai pengaruh mekanisme bonus terhadap transfer pricing telah dilakukan oleh Hartati (2015) dan menghasilkan hasil penelitian bahwa mekanisme bonus berpengaruh secara signifikan terhadap transfer pricing. Berbeda dengan penelitian yang telah dilakukan oleh Mispiyanti (2015) yang mendapatkan kesimpulan bahwa mekanisme bonus tidak berpengaruh terhadap keputusan perusahaan melakukan transfer pricing

Berdasarkan uraian yang berhubungan dengan transfer pricing, pajak, tunneling incentive, serta mekanisme bonus tersebut, maka peneliti akan menguji kembali perusahaan-perusahaan Manufaktur yang terdaftar di Bursa Efek Indonesia periode tahun 2016-2019. Berdasarkan hal tersebut, maka peneliti melakukan penelitian yang berjudul "Analisis Faktor-Faktor Yang Mempengaruhi Penerapan Transfer Pricing Pada Perusahaan Manufaktur Yang Terdaftar Di Bursa Efek Indonesia Tahun 2016-2019".

\section{Perumusan Masalah}

Adapun rumusan masalah yang akan menjadi kajian dalam penelitian ini adalah untuk mengetahui:

1. Apakah pajak berpengaruh terhadap penerapan transfer pricing?

2. Apakah tunneling incentive berpengaruh terhadap penerapan transfer pricing?

3. Apakah mekanisme bonus berpengaruh terhadap penerapan transfer pricing?

\section{Tujuan penelitian}

Tujuan penelitian ini adalah sebagai berikut :

1. Untuk mengetahui apakah pajak berpengaruh terhadap penerapan penerapan transfer pricing.

2. Untuk mengetahui apakah tunneling incentive berpengaruh terhadap penerapan transfer pricing.

3. Untuk mendapatkan bukti empiris mengenai pengaruh mekanisme bonus terhadap penerapan transfer pricing.

\section{LANDASAN TEORI}

\section{Teori Agensi (Agenchy Theory)}

Menurut Scott (2015:358), teori keagenan merupakan cabang dari game theory yang mempelajari skema dari kontrak untuk memotivasi agen yang rasional untuk bertindak sesuai keinginan dari principal. Hubungan agensi ada ketika salah satu pihak (principal) menyewa pihak lain (agen) untuk melaksanakan jasa dan dalam hal tersebut, principal mendelegasikan wewenang kepada agen untuk membuat keputusan. 
Namun, dalam praktiknya kadang kala terjadi konflik yang disebabkan karena masing-masing pihak memiliki kepentingan yang berbeda. Agen sering kali bertindak hanya untuk kepentingannya sendiri dan mengesampingkan kepentingan principal. Hal inilah yang menyebabkan terjadinya konflik, konflik ini disebut dengan konflik keagenan.

Munculnya konflik disebabkan karena adanya asimetri informasi atau adanya kesenjangan informasi antara agen selaku pihak yang menyediakan informasi dengan principal dan stakeholders sebagai pengguna informasi. Informasi lebih banyak dimiliki oleh manajer dapat memicu tindakan oportunistik sesuai dengan kepentingan untuk memaksimalkan utilitasnya. Sedangkan bagi principal sulit mengontrol secara efektif tindakan yang dilakukan oleh manajemen karena hanya memilki sedikit informasi dari seluruh informasi yang ada.

\section{Teori Akuntansi Positif}

Positive accounting theory dikembangkan oleh Watts \& Zimmerman (1986) dimana memaparkan faktor-faktor ekonomi tertentu yang bisa dikaitkan dengan perilaku manajer atau para pembuat laporan keuangan. Sehingga, teori ini diharapkan dapat membantu untuk menjelaskan dan memprediksi praktik akuntansi. Adanya perkembangan dari suatu teori akuntansi positif akan dapat menjelaskan dari why accounting is what it is, why accountants do what they do, dan apa pengaruh dari fenomena ini terhadap manusia dan penggunaan sumber daya (Jensen \& Meckling, 1976 dalam Setijaningsih, 2012).

Dengan teori akuntansi positif ini akan membuat manajer bersikap lebih berhati-hati (konservatisme) dalam melakukan penghindaran pajak. Menjelaskan (to explain) dan memprediksi (to predict) dalam teori akuntansi positif terhadap praktik transfer pricing untuk menekan beban pajak perusahaan.

Dimana Menjelaskan (to explain), memberikan alasan-alasan terhadap praktik transfer pricing dengan motivasi mengurangi beban pajak sehingga laba perusahaan meningkat yang dilakukan manajer dan memprediksi (to predict), kondisi kapan manajer akan melakukan praktik transfer pricing dengan motivasi mengurangi beban pajak sehingga laba perusahaan meningkat dengan memanfaatkan celah-celah yang ada.

\section{Transfer Pricing}

Transfer pricing adalah harga yang terkandung pada setiap produk atau jasa dari satu divisi yang di transfer ke divisi yang lain dalam perusahaan yang sama atau antar perusahaan yang mempunyai hubungan istimewa. Transaksi transfer pricing dapat terjadi pada divisi-divisi dalam satu perusahaan, antar perusahaan lokal, atau perusahaan lokal dengan perusahaan yang ada di luar negeri (Hartati, 2014).

Namun menurut Rahayu (2010) dalam konteks perpajakan transfer pricing dapat digunakan untuk merekayasa pembebanan harga suatu transaksi antara perusahaan-perusahaan yang mempunyai hubungan istimewa atau disebut dengan related parties dalam rangka meminimalkan beban pajak yang terutang secara keseluruhan atas grup perusahaan. Sehingga, untuk mencegah penghindaran pajak karena penentuan harga tidak wajar (non arm's length price), muncul Peraturan Dirjen Pajak No.PER-43/PJ/2010. Aturan ini membahas penerapan prinsip kewajaran dan kelaziman usaha (arm's length principles) terkait transaksi antara 
wajib pajak dengan pihak yang memiliki hubungan istimewa. Aturan ini mengharuskan wajib pajak untuk menggunakan nilai pasar wajar dalam bertransaksi dengan pihak istimewa (Suryana, 2012).

Menurut Pernyataan Standar Akuntansi Keuangan (PSAK) No. 7 Tahun 2010, pihak-pihak yang mempunyai hubungan istimewa adalah bila satu pihak mempunyai kemampuan untuk mengendalikan pihak lain, atau mempunyai pengaruh signifikan atas pihak lain dalam mengambil keputusan. Transaksi antara pihak-pihak yang mempunyai hubungan istimewa adalah suatu pengalihan sumber daya, atau kewajiban antara pihak-pihak yang mempunyai hubungan istimewa, tanpa menghiraukan apakah suatu harga diperhitungkan.

\section{Beban Pajak}

Menurut Pohan (2016) pajak adalah salah satu sumber pendapatan negara yang sangat penting bagi pelaksanaan dan peningkatan pembangunan nasional yang bertujuan untuk meningkatkan kemakmuran dan kesejahteraan masyarakat.

Menurut Waluyo (2016) pajak adalah iuran kepada negara (yang dapat dipaksakan) yang terutang oleh yang wajib membayarnya menurut peraturan peraturan, dengan tidak mendapat prestasi kembali, yang langsung dapat ditunjuk, dan yang gunanya adalah untuk membayar pengeluaran - pengeluaran umum berhubung dengan tugas negara yang menyelenggarakan pemerintahan.

Menurut Undang-Undang Nomor 28 Tahun 2007, pajak adalah kontribusi wajib kepada negara yang terutang oleh orang pribadi atau badan yang bersifat memaksa berdasarkan undang-undang, dengan tidak mendapatkan imbalan secara langsung dan digunakan untuk keperluan negara bagi sebesar-besarnya kemakmuran rakyat. Pungutan wajib yang dibayar rakyat untuk negara dan akan digunakan untuk kepentingan pemerintah dan masyarakat umum. Rakyat yang membayar pajak tidak akan merasakan manfaat dari pajak secara langsung, karena pajak digunakan untuk kepentingan umum bukan untuk kepentingan pribadi.

Berdasarkan PSAK 46 (2014) tentang beban pajak (penghasilan pajak) adalah jumlah gabungan pajak kini dan pajak tangguhan yang diperhitungkan dalam menentukan laba-rugi pada suatu periode kemudian dipadankan dengan dengan laba akuntansi. Beban pajak (penghasilan pajak) terdiri dari beban pajak kini (penghasilan pajak kini) dan beban pajak tangguhan (penghasilan pajak tangguhan).

\section{Tunneling Incentive}

Menurut Johnson (2000) dalam Wafiroh dan Hapsari (2016) kegiatan ekspansi besar-besaram yang dilakukan oleh perusahaan-perusahaan unutk mempercepet pertumbuhannya telah banyak menimbulkan konglomerasi. Konglomerasi memberikan kontribusi besar dalam krisis ekonomi nasional yang sekaligus mendominasi perekonomian nasional, hal ini sering terjadi terutama di Indonesia. Pemegang saham minoritas dan pihak ekternal lainnya sering dirugikan oleh pemegang saham kendali karena berpengaruh kuat yang menyebabkan timbulnya resiko ekploitasi seperti karakteristik kelompok bisnis konglomerat. Kemampuan mengendalikan kegiatan bisnis pada satu pihak muncul akibat kepemilikan saham yang terkonsentrasi pada salah satu pihak pengendali yang akan menimbulkan kegiatan tunneling. Tunneling merupakan aktivitas pengalihan aset 
dalam keuntungan keluar perusahaan untuk kepententingan pemegang saham pengendali perusahaan tersebut.

Menurut Mispiyanti (2015) Tunneling incentive memiliki indikator dengan $20 \%$ atau lebih persentase kepemilikan saham yang dimiliki oleh pemegang saham yang berapa di negara lain dengan ketentuan memiliki tarif pajak lebih rendah dari Indonesia. Selain itu, sesuai dengan PSAK Nomor 15 pengaruh signifikan diperoleh dari presentase $20 \%$ atau lebih kepemilikan saham.

\section{Mekanisme Bonus}

Menurut Hartati (2014), mekanisme bonus direksi dapat diartikan sebagai pemberian imbalan diluar gaji kepada direksi perusahaan atas hasil kerja yang dilakukan dengan melihat prestasi kerja direki itu sendiri. Prestasi kerja yang dilakukan dapat dinilai dan diukur berdasarkan suatu penilaian yang telah ditentukan perusahaan secara objektif.

Selain itu menurut Refgia (2017) mekanisme bonus adalah kompensasi tambahan atau penghargaan yang diberikan kepada pegawai atas keberhasilan pencapaian tujuan-tujuan yang ditargetkan oleh perusahaan. Mekanisme bonus berdasarkan laba merupakan cara yang paling sering digunakan perusahaan dalam memberikan penghargaan kepada direksi atau manajer. Maka, karena berdasarkan tingkat laba direksi atau manajer dapat memanipulasi laba tersebut untuk memaksimalkan penerimaan bonus.

Mengingat bahwa mekanisme bonus berdasarkan pada besarnya laba, yang merupakan cara paling populer dalam memberikan penghargaan kepada direksi/manajer, maka adalah logis bila direksi yang remunerasinya didasarkan pada tingkat laba akan memanipulasi laba tersebut untuk memaksimalkan peneriman bonus dan remunerasinya.

Jadi, dapat disimpulkan bahwa mekanisme bonus merupakan salah satu strategi atau motif perhitungan dalam akuntansi yang tujuannya adalah untuk memberikan penghargaan kepada direksi atau manajemen dengan melihat laba perusahaan secara keseluruhan. Karena sebagai akibat dari adanya praktik transfer pricing maka tidak menutup kemungkinan akan terjaadi kerugian pada salah satu divisi atau subunit.

\section{METODE PENELITIAN}

\section{Jenis Data, Sumber Data dan Objek Penelitian}

Penelitian menggunakan data sekunder. Data yang digunakan yakni diambil dari laporan keuangan dan annual report di Bursa Efek Indonesia (BEI) periode 2016 2019 yang diakses melalui website $h t t p: / / w w w . i d x . c o . i d . ~ A d a p u n ~ O b j e k ~ d a l a m$ penelitian ini adalah perusahaan manufaktur yang terdaftar di Bursa Efek Indonesia. Teknik pengumpulan data yang digunakan dalam penelitian ini adalah studi kepustakaan, observasi dan riset internet. 


\title{
Kerangka Pemikiran
}

\author{
Variabel Independen $\quad$ Variabel \\ Dependen
}

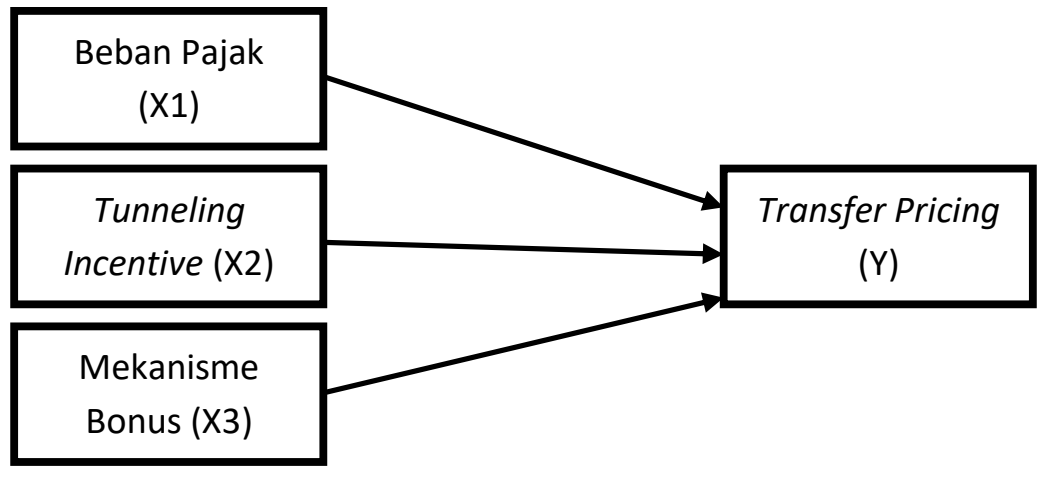

Gambar 1.

Kerangka Pemikiran

\section{Metode Analisis}

Metode analisis data dalam penelitian ini adalah dengan menggunakan teknik analisis kuantitatif. Menggunakan model regresi logistik (logistic regression) dengan bantuan SPSS. Variabel independen non metrik dalam penelitian ini adalah Transfer Pricing yang dinyatakan dengan variabel dummy. Dimana perusahaan yang melakukan transfer pricing diberi kode 1 dan untuk perusahaan yang tidak melakukan transfer pricing diberi nilai 0 .

Dalam penelitian ini digunakan analisis regresi logistik. Analisis dilakukan dengan melihat pengaruh masing-masing variabel independen terhadap variabel dependen. Adapun model regresi logistik yang terbentuk adalah:

$$
\begin{array}{ll}
\operatorname{Ln}(\mathbf{Y} / \mathbf{1}-\mathbf{Y})= & \boldsymbol{\beta} \mathbf{0}+\boldsymbol{\beta} \mathbf{1 X} \mathbf{1}+\boldsymbol{\beta} \mathbf{2} \mathbf{2}+\boldsymbol{\beta 3} \mathbf{X} \mathbf{3}+\boldsymbol{\varepsilon} \\
\begin{array}{l}
\text { Keterangan: } \\
\text { Ln }(\mathrm{Y} / 1-\mathrm{Y})
\end{array} & =\text { Logaritma probabilitas perusahaan melakukan } \\
& \text { transfer pricing } \\
\beta 0 & =\text { Konstanta } \\
\mathrm{X} 1 & =\text { Beban Pajak } \\
\mathrm{X} 2 & =\text { Tunneling Incentive } \\
\mathrm{X} 3 & =\text { Mekanisme Bonus } \\
\beta 1-\beta 2-\beta 3 & =\text { Koefisien regresi variabel Independen } \\
\varepsilon & =\text { Error term }
\end{array}
$$

\section{Teknik Analisis Data}

Langkah - langkah analisis dalam uji regression logistic adalah sebagai berikut:

1. Menilai Keseluruhan Model

Uji ini digunakan untuk menilai model yang telah dihipotesiskan telah fit atau tidak dengan data. Hipotesis untuk menilai model fit adalah: 
$\mathrm{H}_{0}$ : Model yang dihipotesiskan fit dengan data

$\mathrm{H}_{\mathrm{a}}$ : Model yang dihipotesiskan tidak fit dengan data

Dari hipotesis ini, agar model fit dengan data maka $\mathrm{H} 0$ harus diterima. Statistik yang digunakan berdasarkan Likelihood. Likelihood L dari model adalah probabilitas bahwa model yang dihipotesiskan menggambarkan data input. Adanya pengurangan nilai antara $-2 \log \mathrm{L}$, awal (initial $-2 \log \mathrm{L}$, function) dengan nilai -2LogL pada langkah berikutnya menunjukkan bahwa model yang dihipotesiskan Fit dengan data (Ghozali, 2016).

2. Menilai Kelayakan Model Regresi

Kelayakan model regresi dinilai dengan menggunakan Hosmer and Lemeshow Goodness of Fit Test. Hipotesis untuk menilai kelayakan model regresi adalah:

$\mathrm{H}_{0}$ : Tidak ada perbedaan antara model dengan data

$\mathrm{H}_{1}$ : Ada perbedaan antara model dengan data

Jika nilai statistik Hosmer and Lemeshow Goodness of Fit kurang dari 0,05 , maka hipotesis nol ditolak yang berarti ada perbedaan signifikansi antara model dengan nilai observasinya sehingga Goodness of Fit model tidak baik karena model tidak dapat memprediksi nilai observasinya. Jika nilai Hosmer and Lemeshow Goodness of Fit lebih besar daripada 0,05 maka hipotesis nol tidak dapat ditolak dan berarti model mampu memprediksi nilai observasinya atau dapat dikatakan model dapat diterima karena sesuai dengan data observasinya (Ghozali, 2016:329).

\section{Hipotesis Penelitian}

Adapun hipotesis yang akan diuji adalah sebagai berikut:

$\mathrm{H}_{01}$ : Pajak tidak berpengaruh terhadap keputusan perusahaan melakukan Transfer Pricing

$\mathrm{H}_{\mathrm{a} 1}$ : Pajak berpengaruh terhadap keputusan perusahaan melakukan Transfer Pricing

$\mathrm{H}_{02}$ : Tunneling Incentive tidak berpengaruh terhadap keputusan perusahaan melakukan Transfer Pricing

$\mathrm{H}_{\mathrm{a} 2}$ : Tunneling Incentive berpengaruh terhadap keputusan perusahaan melakukan Transfer Pricing

$\mathrm{H}_{03}$ : Mekanisme Bonus tidak berpengaruh terhadap keputusan perusahaan melakukan Transfer Pricing

$\mathrm{H}_{\mathrm{a} 3}$ : Mekanisme Bonus berpengaruh terhadap keputusan perusahaan melakukan Transfer Pricing

\section{Variabel dan Skala Penelitian}

\section{Variable Independen}

Variabel independen dalam penelitian ini ada tiga yaitu Beban Pajak, Tunneling Incentive, dan Mekanisme Bonus.

\section{a. Beban Pajak (X1)}

Pajak penghasilan yang dihitung berbasis pada penghasilan kena pajak yang sesungguhnya dibayar kepada pemerimtah, disebut sebagai sebagai $\mathrm{PPh}$ terutang sedangkan pajak penghasilan yang dihitung berbasis 
penghasilan sebelum pajak disebut sebagai beban pajak penghasilan (Zain, 2008).

Salah satu cara mengukur seberapa baik sebuah perusahaan mengelola pajaknya adalah dengan melihat tarif pajak efektifnya. Pajak dalam penelitian ini diproksikan dengan effective tax rate yang merupakan perbandingan tax expense dikurangi deferred tax expense dibagi dengan laba sebelum pajak (Yuniasih et al., 2012).

$$
\text { ETR }=\frac{\text { Tax Expense }- \text { Differed Tax Expense }}{\text { Earning Before Tax }} \times 100 \%
$$

\section{b. Tunneling Incentive (X2)}

Pada penelitian ini didasarkan pada besarnya kepemilikan saham yang melebihi $20 \%$ (dua puluh persen). Entitas dianggap berpengaruh signifikan baik secara langsung ataupun tak langsung terhadap entitas lainnya apabila menyertakan modal $20 \%$ atau lebih berdasarkan Pernyataan Standar Akuntansi Keuangan (PSAK) No. 15.

Tunneling incentive adalah suatu perilaku dari pemegang saham mayoritas yang mentransfer aset dan laba ke perusahaan untuk kepentingan mereka sendiri, namun pemegang saham minoritas ikut menanggung biaya yang mereka bebankan (hartati et al., 2015).

Pemindahan aset dan laba dapat dilakukan dengan berbagai cara, salah satunya adalah dengan melalui transfer pricing (Noviastika et al., 2016) Transaksi ini digunakan untuk tujuan demi meningkatkan keuntungan laba pemegang saham mayoritas Menurut Wafiroh dan Hapsari (2015). Menurut Andraeni (2017) Variabel Tunneling incentive diproksikan dengan perhitungan:

$$
\text { TNC }=\frac{\text { Kepemilikan Saham Terbanyak }}{\text { Jumlah Saham Yang Beredar }} \times 100 \%
$$

\section{c. Mekanisme Bonus (X3)}

Agar manajer termotivasi mau bekerja lebih baik dan keras maka pemilik menjanjikan sejumlah bonus yang akan diberikan apabila kinerja yang dicapainya di atas rata-rata periode sebelumnya (Sulistyanto, 2008). Mekanisme bonus adalah salah satu kebijakan dalam akuntansi yang populer untuk meningkatkan kinerja direksi dalam meningkatkan laba perusahaan dan ini dapat memaksimalkan penerimanaan kompensasi bonus kepada direksi atas hasil kinerja yang baik terhadap perusahaan, karena menyangkut kesejahteraan para eksekutif di internal perusahaan (Gayatrie 2014). Sehingga untuk variabel ini akan diukur dengan rumus ITRENDLB yaitu berdasarkan prosentase pencapaian laba bersih pada tahun t terhadap laba bersih pada tahun t-1 (Suryatiningsih 2009) dan (Irpan 2010).

$$
\text { ITTRENDLB }=\frac{\text { Laba Bersih Tahun } t}{\text { Laba Bersih Tahun } t-1} \times 100 \%
$$

\section{Variable Dependen (Y) Transfer Pricing}


Menurut Noviastika, dkk. (2016) dalam Saraswati dan Sujana (2017) variabel transfer pricing diukur salah satunya dengan mendeteksi terjadinya penjualan kepada pihak istimewa. Penjualan kepada pihak istimewa diindikasikan terdapat transfer pricing. Penentuan harga terhadap penjualan kepada pihak berelasi biasanya mengesampingkan prinsip kewajaran bisa dengan menaikkan atau menurunkan harga.

Menurut Refgia (2017) transfer pricing merupakan suatu kebijakan perusahaan dalam menentukan keputusan untuk menentukan harga transfer antara pihak-pihak yang memiliki hubungan istimewa. Harga transfer tersebut digunakan untuk transaksi seperti barang, jasa, harta tidak berwujud, ataupun transaksi financial dengan tujuan memaksimalkan laba.

Penelitian ini menggunakan nilai transaksi pihak berelasi karena transfer pricing dan transaksi pihak berelasi merupakan transaksi yang memiliki hubungan istimewa. variabel transfer pricing diproksikan dengan ada atau tidaknya penjualan kepada pihak istimewa. Penjualan kepada pihak istimewa diindikasikan terdapat praktik transfer pricing. Harga yang ditetapkan dalam penjualan terhadap pihak berelasi biasanya mengesampingkan prinsip kewajaran bisa dengan menaikkan atau menurunkan harga (Noviastika dkk. 2016).

Kriteria dummy yang digunakan adalah nilai 1 apabila perusahaan melakukan transaksi penjualan kepada pihak istimewa, sedangkan nilai 0 untuk entitas yang tidak mengadakan transaksi penjualan kepada pihak istimewa. (Hartati et al., 2015).

\section{Operasional Variabel dan Skala Pengukuran}

Operasional variabel diperlukan untuk menjabarkan variabel penelitian dalam konsep indikator yang bertujuan memudahkan pengertian dan menghindari perbedaan persepsi pada penelitian ini. Operasional variabel dalam penelitian ini adalah kualitas audit, komisaris independen dan ukuran perusahaan sebagai variabel independent serta penghindaran pajak sebagai variabel dependen yang dapat dilihat dalam tabel berikut:

Tabel 1

Variable Operasional Penelitian

\begin{tabular}{|c|c|c|}
\hline Variabel & Skala pengukuran & Skala Data \\
\hline Transfer Pricing (Y) & $\begin{array}{c}\text { Perusahaan yang melakukan } \\
\text { penjualan kepada pihak yang } \\
\text { mempunyai hubungan istimewa } \\
\text { (Hartati et al., 2015) }\end{array}$ & Nominal \\
& $\begin{array}{c}\text { diberi nilai 1 dan yang tidak diberi } \\
\text { nilai 0 (Dummy) }\end{array}$ & \\
\hline
\end{tabular}




\begin{tabular}{|c|c|c|}
\hline $\begin{array}{c}\text { Beban Pajak (X1) } \\
\text { (Yuniasih et al., 2012) }\end{array}$ & $\begin{array}{l}\text { Beban Pajak diperoleh dengan cara } \\
\text { menghitung tarif pajak efektif entitas: } \\
\text { ETR }=\frac{\text { Tax Expense - Differed Tax Expense }}{\text { Earning Before Tax }} \times 100 \%\end{array}$ & Rasio \\
\hline $\begin{array}{c}\text { Tunneling Incentive } \\
\text { (X2) } \\
\text { (Andraeni, 2017) }\end{array}$ & $\begin{array}{l}\text { Variabel tunneling incentive dapat } \\
\text { diproksikan dengan perhitungan : } \\
\text { TNC }=\frac{\text { Kepemilikan Saham Terbanyak }}{\text { Jumlah Saham Yang Beredar }} \times \mathbf{1 0 0 \%}\end{array}$ & Rasio \\
\hline
\end{tabular}

\section{Populasi dan Sampel}

Populasi dalam penelitian ini adalah seluruh perusahaan manufaktur yang terdfatar pada Bursa Efek Indonesia (BEI) periode tahun 2016-2019 Teknik penentuan sampel yang akan digunakan dalam penelitian ini adalah teknik purposive sampling. Berikut adalah kriteria perusahaan yang dijadikan sampel dalam penelitian ini:

1. Perusahaan manufaktur yang berturut turut terdaftar di Bursa Efek Indonesia periode 2016-2019.

2. Perusahaan Manufaktur yang dikendalikan oleh perusahaan lain ataupun perusahaan afiliasi dengan persentase kepemilikan 20\% atau lebih (PSAK No.15).

3. Perusahaan Manufaktur yang konsisten mengalami laba selama periode penelitian.

4. Perusahaan Manufaktur yang menggunakan mata uang Rupiah

5. Perusahaan manufaktur yang menyediakan informasi lengkap terkait variable penelitian periode $2016-2019$.

\section{HASIL DAN PEMBAHASAN}

\section{Deskripsi Objek Penelitian}

Objek dalam penelitian ini adalah seluruh perusahaan manufaktur yang terdaftar di BEI periode 2016-2019 dengan total populasi sebanyak 192 perusahaan manufaktur. Berdasarkan teknik purposive sampling yang dapat dilihat pada tabel 2, maka diperoleh sampel sebanyak 65 perusahaan manufaktur dan dengan periode penelitian selama 4 tahun maka total sampel penelitian ini berjumlah 260 .

Tabel 2

Proses Pemilihan Sampel

\begin{tabular}{|c|l|c|c|}
\hline No & \multicolumn{1}{|c|}{ Kriteria } & $\begin{array}{c}\text { Tidak } \\
\text { sesuai } \\
\text { kriteria }\end{array}$ & akumulasi \\
\hline 1 & $\begin{array}{l}\text { Perusahaan Manufaktur yangterdaftar di BEI periode } \\
2016-2019 \text { (Populasi) }\end{array}$ & & 192 \\
\hline
\end{tabular}




\begin{tabular}{|c|c|c|c|}
\hline 2 & $\begin{array}{l}\text { Perusahaan Manufaktur yang tidak menerbitkan laporan } \\
\text { keuangannya per } 31 \text { Desember periode 2016-2019 }\end{array}$ & $(6)$ & 186 \\
\hline 3 & $\begin{array}{l}\text { Perusahaan Manfaktur yang tidak terdaftar secara } \\
\text { berturut-turut periode 2016-2019 }\end{array}$ & $(40)$ & 146 \\
\hline 4 & $\begin{array}{l}\text { Perusahaan Manufaktur yang menggunakan mata uang } \\
\text { selain } \\
\text { rupiah di laporan keuangannya periode 2016-2019 }\end{array}$ & $(22)$ & 124 \\
\hline 5 & $\begin{array}{l}\text { Perusahaan Manufaktur yang mengalami rugi periode } \\
\text { 2016-2019 }\end{array}$ & $(9)$ & 115 \\
\hline 6 & $\begin{array}{l}\text { Perusahaan Manufaktur yang tidak menyediakan } \\
\text { informasi lengkap terkait variabel penelitian periode } \\
\text { 2016-2019 }\end{array}$ & $(28)$ & 87 \\
\hline 7 & $\begin{array}{l}\text { Perusahaan Manufaktur yang tidak memiliki kepemilikan } \\
\text { saham entitas lain lebih dari } 20 \% \text { periode } 2016-2019\end{array}$ & $(22)$ & 65 \\
\hline \multicolumn{2}{|r|}{ Jumlah Perusahaan Manufaktur yang terpilih menjadi sampel } & & 65 \\
\hline \multicolumn{2}{|c|}{ Periode Penelitian $2016-2019$ ( 4 tahun ) } & & 4 \\
\hline \multicolumn{2}{|c|}{ Total sampel penelitian } & & 260 \\
\hline
\end{tabular}

Sumber: Data Diolah Sendiri, 2020

\section{Statistik Deskriptif}

Tabel 3

Descriptive Statistics

\begin{tabular}{|l|r|r|r|r|r|}
\hline & N & Minimum & Maximum & Mean & Std. Deviation \\
\hline ETR (X1) & 260 &, 01 &, 97 &, 2826 &, 14173 \\
TNC (X2) & 260 &, 21 &, 93 &, 5591 &, 21542 \\
ITTRENDLB (X3) & 260 &, 0500 & 915,1000 & 6,540615 & 65,4755993 \\
TP (Y) & 260 &, 0 & 1,0 &, 964 &, 1865 \\
Valid N (listwise) & 260 & & & & \\
\hline
\end{tabular}

Berdasarkan hasil output SPSS 23 yang dapat dililhat pada tabel 3 di atas menunjukkan jumlah sampel $(\mathrm{N})$ sebanyak 260 . Nilai rata rata yang diperoleh dari variable beban pajak adalah sebesar $28,26 \%$ lebih besar dari nilai standar deviasinya $14,17 \%$. Hal ini menunjukkan bahwa ada $28,26 \%$ dari total 260 sampel mampu menghasilkan laba bersih setelah bunga dan pajak sebesar $28,26 \%$ dari penjualan bersihnya. Nilai rata-rata (mean) variabel Tunneling Incentive sebesar 55,9\% dengan standar deviasi sebesar $21,5 \%$. Hal ini menunjukkan bahwa dari 260 sampel tersebut rata-rata perusahaan mempunyai kepemilikan saham mayoritas dengan kepemilikan saham diatas $20 \%$ sebagai pengendalinya. Nilai rata-rata (mean) variabel mekanisme bonus sebesar 654,06\% dengan standar deviasi 6547,55\%. Hal ini menunjukan bahwa sebagian besar sampel penelitian mengalami peningkatan laba sekitar 6 kali lipat setiap tahunnya. Untuk variabel Transfer pricing yang menunjukkan nilai minimum sebesar 0 dan nilai maksimumnya sebesar 1 . Sementara untuk nilai mean sebesar 0,96 dengan standar deviasi sebesar 0,187. Hal ini menunjukkan bahwa ada 96\% dari total 260 sampel perusahaan yang melakukan praktik transfer pricing dan sisanya sejumlah $4 \%$ tidak melakukan Transfer pricing. 


\section{Menilai Keseluruhan Model Fit}

Tabel 4

Pengujian -2log likelihood Block 0

Iteration History ${ }^{a, b, c}$

\begin{tabular}{|lc|c|c|}
\hline & & & Coefficients \\
\cline { 4 - 4 } & Iteration & -2 Log likelihood & Constant \\
\hline $\mathrm{S}$ & 1 & 82,605 & 1,856 \\
$\mathrm{e}$ & 2 & 63,110 & 2,705 \\
$\mathrm{p}$ & 3 & 60,443 & 3,161 \\
& 4 & 60,325 & 3,283 \\
0 & 5 & 60,325 & 3,291 \\
& 6 & 60,325 & 3,291 \\
\hline
\end{tabular}

a. Constant is included in the model.

b. Initial -2 Log Likelihood: 60,325

c. Estimation terminated at iteration number 6 because parameter estimates changed by less than ,001.

Sumber: Hasil Output SPSS 23, 2020

Tabel 5

Pengujian -2log likelihood Block 1

\begin{tabular}{|c|c|c|c|c|c|c|}
\hline \multirow[b]{2}{*}{ Iteratiol } & & \multirow[b]{2}{*}{-2 Log likelihood } & \multicolumn{4}{|c|}{ Coefficients } \\
\hline & & & Constant & ETRX1 & TNCX2 & ITTRENDLBX3 \\
\hline \multirow[t]{12}{*}{ Step 1} & 1 & 72,875 & 2,065 & $-2,265$ & ,768 &, 000 \\
\hline & 2 & 44,182 & 2,796 & $-3,969$ & 2,090 & ,001 \\
\hline & 3 & 33,861 & 2,636 & $-5,071$ & 4,551 & ,002 \\
\hline & 4 & 28,703 & 1,818 & $-5,945$ & 8,312 &, 003 \\
\hline & 5 & 25,937 & ,775 & $-7,048$ & 13,137 &, 007 \\
\hline & 6 & 24,419 &,- 316 & $-8,425$ & 18,318 & ,050 \\
\hline & 7 & 23,573 & $-1,151$ & $-9,619$ & 22,037 & ,166 \\
\hline & 8 & 23,193 & $-1,534$ & $-10,160$ & 23,390 & ,327 \\
\hline & 9 & 23,072 & $-1,714$ & $-10,258$ & 23,620 & ,478 \\
\hline & 10 & 23,059 & $-1,783$ & $-10,300$ & 23,705 &, 546 \\
\hline & 11 & 23,059 & $-1,792$ & $-10,308$ & 23,721 &, 554 \\
\hline & 12 & 23,059 & $-1,792$ & $-10,308$ & 23,721 &, 554 \\
\hline
\end{tabular}

a. Method: Enter

b. Constant is included in the model.

c. Initial -2 Log Likelihood: 60,325

d. Estimation terminated at iteration number 12 because parameter estimates changed by less than ,001.

Sumber: Hasil Output SPSS 23, 2020

Jurnal Ilmiah Akuntansi dan Ekonomi Volume. 5 Nomor. 2, Agustus 2020 Hal. 30 
Pada tabel 5 di atas dimana 3 variabel independen sudah dimasukkan ke dalam model menunjukkan nilai -2 log likehood akhir (Blok 1: Method Enter) sebesar 23,059. Hal ini menunjukkan bahwa terdapat penurunan nilai $-2 \log$ likelihood yaitu sebesar 37,266. Penurunan nilai $-2 \log$ likelihood ini menunjukkan bahwa dengan memasukkan variabel independen ke dalam model dapat memperbaiki model fit serta menunjukkan model regresi yang lebih baik, yang berarti $\mathrm{H} 0$ diterima dengan kata lain model fit dengan data dan dapat melanjutkan proses pengujian selanjutnya.

\section{Menilai Kelayakan Model Regresi}

Dalam penelitian ini untuk menilai kelayakan model regresi dengan menggunakan Hosmer and Lemeshow's Goodness of Fit Test (Ghozali, 2016:329). Hipotesis yang digunakan untuk menilai keayakan model regresi adalah sebagai berikut:

1. Jika nilai Statistics Hosmer and Lemeshow's Goodness of Fit Test $<0,05$ maka H0 ditolak, yang berarti bahwa model tidak dapat memprediksi nilai observasinya.

2. Jika nilai Statistics Hosmer and Lemeshow's Goodness of Fit Test $>0,05$ maka H0 diterima, yang berarti bahwa model dapat memprediksi nilai observasinya.

Hasil pengujian kelayakan model regresi dapat dilihat pada tabel berikut:

Tabel 6

\section{Pengujian Hosmer and Lemeshow}

Hosmer and Lemeshow Test

\begin{tabular}{|l|r|r|r|}
\hline Step & Chi-square & Df & Sig. \\
\hline 1 & 4,775 & & 8
\end{tabular}

Sumber: Hasil Output SPSS 23, 2020

Hasil yang dapat dilihat pada tabel 6 di atas menunjukkan nilai chisquare sebesar 4,775 dengan nilai signifikansi 0,781 >0,05, dengan nilai signifikansi yang lebih besar dari 0,05 maka H0 diterima. Hal ini berarti bahwa tidak ada perbedaan antara model dengan data. Dengan demikian dapat disimpulkan bahwa model dapat memprediksi nilai observasinya atau dapat dikatakan model dapat diterima karena cocok dengan data observasinya.

\section{Uji Koefisien Determinasi}

Pengujian koefisien determinasi digunakan untuk mengetahui seberapa jauh kemampuan model variabel independen yaitu beban Pajak, Tunneling Incentive. dan mekanisme bonus dalam menerangkan variasi variabel dependen yaitu transfer pricing. Dalam model regresi logistik besarnya nilai koefisien determinasi ditunjukkan dengan nilai Nagelkerke R Square yang dapat diinterpretasikan seperti nilai R2 pada regresi berganda. 
Tabel 7

Pengujian Koefisien Determinasi

Model Summary

\begin{tabular}{|l|c|c|c|}
\hline Step & $\begin{array}{c}-2 \text { Log } \\
\text { likelihood }\end{array}$ & $\begin{array}{c}\text { Cox \& Snell R } \\
\text { Square }\end{array}$ & $\begin{array}{c}\text { Nagelkerke } R \\
\text { Square }\end{array}$ \\
\hline 1 & $23,059^{\text {a }}$ &, 174 &, 654 \\
\hline
\end{tabular}

Pada tabel 7 di atas menunjukkan nilai Nagelkerke R Square yaitu sebesar 0,654 yang menunjukkan bahwa kemampuan variabel independen yaitu Beban pajak, Tunneling Incentive dan Mekanisme Bonus dalam menjelaskan variabel dependen yaitu Transfer Pricing sebesar 65,4\%, sedangkan sisanya sebanyak $34,6 \%$ variabel lain diluar model penelitian yang dapat menjelaskan variabel Transfer Pricing.

\section{Uji Omnibus}

Pengujian ini dilakukan dengan tujuan untuk mengetahui pengaruh secara simultan variabel independen terhadap variabel dependen atau minimal ada satu variabel independen yang berpengaruh terhadap variabel dependen. Omnibus test ini mirip dengan uji $\mathrm{F}$ pada nalisis regresi linier berganda. Nilai pada uji ini dapat dilihat dengan menggunakan nilai pvalue yang dibandingkan dengan nilai $\alpha$, dengan kriteria pengambilan keputusan sebagai berikut:

1. Jika p-value $>\alpha(0,05)$, maka variabel-variabel independen secara simultan tidak berpengaruh terhadap penghindaran pajak atau $\mathrm{HO}$ diterima.

2. Jika p-value $<\alpha(0,05)$, maka variabel-variabel independen secara simultan berpengaruh atau minimal ada satu variabel independen yang berpengaruh terhadap Transfer Pricing atau H0 ditolak.

Tabel 8

Omnibus Tests of Model Coefficients

\begin{tabular}{|rl|r|r|r|}
\hline & & Chi-square & \multicolumn{1}{c|}{ df } & \multicolumn{1}{c|}{ Sig. } \\
\hline Step 1 & Step & 37,266 & 3 &, 000 \\
& Block & 37,266 & 3 &, 000 \\
& Model & 37,266 & 3 &, 000 \\
\hline
\end{tabular}

Dapat dilihat pada Tabel 8 di atas hasil omnibus test menunjukkan bahwa nilai pvalue sebesar $0,00<0,05$. Nilai p-value yang menunjukkan lebih kecil dari tingkat signifikansi sebesar 0,05, maka H0 ditolak yang berarti bahwa beban pajak, tunneling incentive dan mekanisme bonus secara simultan berpengaruh terhadap praktik transfer pricing.

\section{Pengujian Hipotesis}

Pengujian hipotesis dalam penelitian ini bertujuan untuk mengetahui pengaruh beban pajak, Tunneling incentive dan mekanisme bonus sebagai variabel 
independen terhadap penghindaran pajak sebagai variabel dependen. Pengujian hipotesis ini dilakukan dengan menggunakan hasil uji regresi logistik yang ditunjukkan dengan tabel hasil ouput spss variables in equation dengan nilai pada kolom significant yang dibandingkan dengan tingkat kealphaan 5\%. Hasil pengujian ini dapat dilihat pada tabel berikut:

Tabel 9

Pengujian Hipotesis

Variables in the Equation

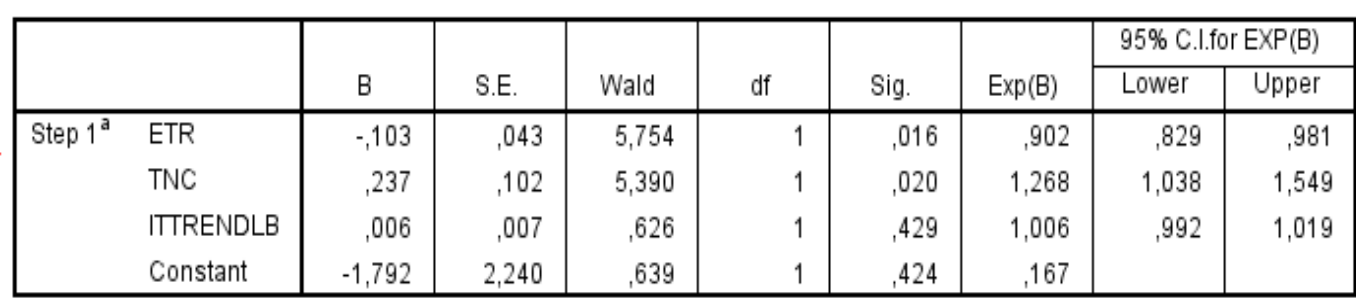

a. Variable(s) entered on step 1: ETR, TNC, ITTRENDLB

Sumber: Hasil Output SPSS 23, 2020

Dapat dilihat pada tabel 9, menunjukkan hasil uji regresi logistik pada tingkat signifikansi $(\alpha)$ 5\%. Dari hasil pengujian regresi logistik tersebut, maka persamaan regresinya adalah sebagai berikut:

$\operatorname{Ln}(\mathrm{Y} / 1-\mathrm{Y})=-1,792-0,103 E T R+0,237 T N C+0,006$ ITTRENDLB $+\varepsilon$

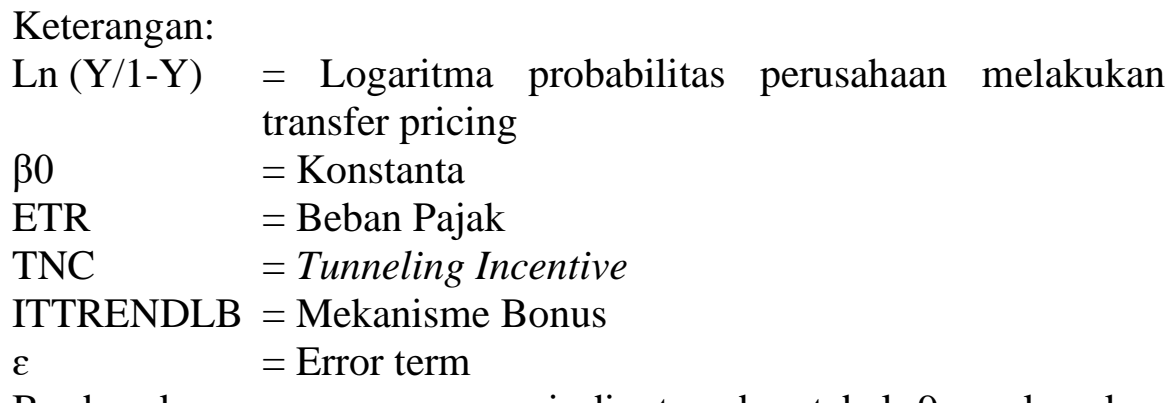
dijelaskan analisis sebagai berikut:

1. Nilai konstanta pada persamaan regresi di atas sebesar -1,792 artinya jika beban pajak, Tunneling Incentive dan mekanisme bonus tidak diperhitungkan, maka praktik transfer pricing adalah sebesar -1,792.

2. Hasil pengujian hipotesis pertama menunjukkan bahwa variabel dari Beban pajak mempunyai koefisien regresi negatif sebesar -0,103 dengan tingkat signifikansi sebesar 0,016 yang lebih kecil dari $\alpha(5 \%)$. Koefisien regresi negatif menunjukkan setiap kenaikan Beban Pajak (ETR) sebesar 1 (satu) poin maka kecenderungan terjadi penurunan tindakan Transfer Pricing sebesar 0,103. Koefisien variabel beban pajak yang bernilai negatif menunjukkan bahwa hubungan beban pajak dengan praktik transfer pricing berlawanan, jika beban pajak meningkat maka transfer pricing menurun dan begitu juga sebaliknya. 
3. Hasil pengujian hipotesis kedua menunjukan bahwa variabel Tunneling Icnentive yg dihitung dengan membandingkan jumlah kepemillikan saham terbesar dengan jumlah seluruh saham yang beredar mempunyai nilai koefisien regeresi positif sebesar 0,237 dengan tingkat signifikansi sebesar 0,02 yang lebih kecil dari $\alpha(5 \%)$. Koefisien regresi positif menunjukkan setiap kenaikan Tunneling Incentive (TNC) sebesar 1 (satu) poin maka kecenderungan terjadi peningkatan praktik transfer pricing sebesar 0,237. Koefisien variabel Tunneling incentive yang bernilai positif menunjukkan bahwa hubungan Tunneling Incentive dengan praktik transfer pricing searah, jika tunnelling incentive naik maka praktik transfer pricing juga naik dan begitu sebaliknya.

4. Hasil pengujian hipotesis ketiga menunjukkan bahwa variabel mekanisme bonus yang dihitung dengan membandingkan laba perusahaan pada tahun berjalan dengan laba perusahaan pada tahun sebelumnya memiliki nilai koefisien regresi positif sebesar 0,006 dengan tingkat signifikansi sebesar 0,429 yang lebih besar dari $\alpha(5 \%)$. Koefisisen regresi positif menunjukkan setiap kenaikan mekanisme bonus (ITTRENDLB) sebesar 1 (satu) poin maka kecenderungan terjadi praktik transfer pricing sebesar 0,006. Koefisien variabel mekanisme bonus yang bernilai positif menunjukkan bahwa hubungan mekanisme bonus dengan transfer pricing searah, yang berarti jika mekanisme bonus meningkat maka praktik transfer pricing juga meningkat dan begitu juga sebaliknya.

\section{Interpretasi Hasil penelitian}

\section{Pengaruh beban pajak terhadap praktik transfer pricing}

Pada tabel 9, kita ketahui dimana beban pajak yang ditentukan dengan nilai efektifitas rasio pajak nya (ETR) menunjukkan nilai koefisien sebesar $-0,103$ dengan tingkat signfikansi sebesar 0,016. Dimana hal ini menunjukkan bahwa tingkat signifikansi beban pajak lebih kecil dari $\alpha(5 \%)$, yaitu $0,016<0,05$. Kesimpulan dari hasil uji tersebut bahwa Hal diterima, yang berarti bahwa variabel beban pajak berpengaruh terhadap transfer pricing. Hal ini menunjukan bahwa alasan perusahaan melakukan transfer pricing adalah karena besarnya beban pajak, terutama pajak penghasilannya. Tujuan utama perusahaan melakukan transfer pricing salah satunya adalah untuk menekan beban pajak yang semakin besar karena dalam praktik bisnis, pengusaha mengidentifikasi pembayaran pajak sebagai beban sehingga cenderung diminimalkan dengan cara transfer pricing, bila beban pajak ditekan makan cost berkurang dan laba meningkat. Hasil penelitian ini sesuai atau sejalan dengan penelitian yang dilakukan oleh Wafiroh dan Hapsari (2016). Namun tidak sejalan dengan penelitian yang dilakukan oleh Mispiyanti (2015).

\section{Pengaruh Tunneling Incentive terhadap praktik transfer pricing}

Berdasarkan hasil pengujian hipotesis pada tabel 9, menunjukan koefisien dari tunneling incentive sebesar 0,0237 dengan tingkat signifikansi sebesar 0,02. Dimana hal ini menunjukkan bahwa tingkat signifikansi lebih kecil dari $\alpha(5 \%)$, yaitu $0,02<0,05$. Kesimpulan dari hasil pengujian menunjukkan $\mathrm{Ha} 2$ diterima, yang berarti bahwa tunnelling incentive berpengaruh terhadap praktik transfer

Jurnal Ilmiah Akuntansi dan Ekonomi Volume. 5 Nomor. 2, Agustus 2020 Hal. 34 
pricing. Hal ini menunjukkan bahwa semakin banyak kepemilikan saham mayoritas maka semakin cenderung perusahaan melakukan transfer pricing dengan tujuan utama adalah menghasilkan lebih banyak laba untuk pengendalinya. Jika pemilik saham mayoritas mempunyai kepemilikan yangbesar, dengan kata lain mereka telah menanamkan modal yang juga besar kedalam perusahaan tersebut. Maka otomatis mereka juga menginginkan pengembalian atau dividen yang besar pula. Untuk itu ketika dividen yang dibagikan perusahaan tersebut harus dibagi dengan pemilik saham minoritas, maka pemiliksaham mayoritas lebih memilih untukmelakukan transfer pricing dengan cara mentransfer kekayaan perusahaan untuk kepentinganya sendiri dari pada membagi dividennya kepada pemilik saham minoritas. Oleh sebab itu, semakin besar kepemilikan pemegang saham maka akan semakin memicu terjadinya praktik transfer pricing. Hasil penelitian ini sejalan atau mendukung penelitian yang dilakukan oleh Mispiyanti (2015) yang menyatakan tunnelling incentive berpengaruh terhadap keputusan transfer pricing.

\section{Pengaruh Mekanisme Bonus terhadap praktik transfer pricing}

Berdasarkan hasil pengujian hipotesis yang telah dilakukan sebelumnya yang dapat dilihat pada tabel 9, menunjukkan bahwa koefisien dari ukuran perusahaan sebesar 0,006 dengan tingkat signifikansi sebesar 0,429. Tingkat signifikansi 0,429 > 0,05 memberi kesimpulan Ha3 ditolak, yang berarti bahwa mekanisme bonus tidak berpengaruh terhadap praktik transfer pricing. Artinya, jika hanya karena motif untuk mendapatkan bonus, tidak seharusnya direksi berani melakukan transaksi transfer pricing untuk meningkatkan laba perusahaan tetapi direksi dapat melakukan manajemen perusahaan yang baik yang dapat berpengaruh terhadap pencapaian laba yang maksimal, mengingat hal ini sangat tidak etis karna manajemen perusahaan harus menjaga nilai perusahaan dimata masyarakat. Hasil penelitian ini selaras atau mendukung penelitian yang telah dilakukan oleh Saraswati dan Sujana (2017) serta Mispiyanti (2017) yang menyatakan bahwa mekanisme bonus tidak berpengaruh terhadap penerapan transfer piricing perusahaan. Sementara hasil penelitian ini tidak selaras dengan penelitian yang dilakukan oleh Refgia (2017), Wafiroh dan Hapsari (2016) yang menyatakan sebaliknya, mekanisme berpengaruh dalam penerapan transfer pricing perusahaan.

\section{KESIMPULAN DAN SARAN}

\section{Kesimpulan}

Berdasarkan hasil analisis yang telah dijelaskan pada bab sebelumnya dimana penelitian ini bertujuan untuk mengetahui pengaruh variabel independen yang terdiri dari beban pajak, tunneling incentive, dan mekanisme bonuse terhadap variabel dependen yaitu penerapan transfer pricing pada perusahaan manufaktur yang terdaftar di Bursa Efek Indonesia periode 2016-2018, maka kesimpulan dari penelitian ini adalah sebagai berikut:

1. Beban pajak berpengaruh negatif terhadap penerapan transfer pricing. Hal ini dapat dilihat dengan besaran tingkat signifikansi pada table 4.8 variable in the Equation sebesar 0,016 
2. Tunneling Incentive juga berpengaruh terhadap penerapan transfer pricing, yang mempunyai nilai signifikansi sebesar 0,02 yang dapat kita lihat pada table 4.8 variable in the Equation

3. Namun, berbeda dengan variable mekanisme bonus yang tidak berpengaruh terhadap penerapan transfer pricing dengan nilai signifikansi sebesar 0,429 yang dapat dilihat dalam table 4.8 variable in the Equation

\section{Saran}

Berdasarkan kesimpulan dan keterbatasan dalam penelitian ini, maka saran untuk penelitian selanjutnya dengan variabel dependen yang sama adalah sebagai berikut:

1. Penelitian selanjutnya diharapkan dapat menambah atau menggunakan variabel independen lain yang diteliti sehingga dapat lebih akurat dalam memprediksi pengaruhnya terhadap penerapan transfer picing. Berdasarkan teori serta penelitian sebelumnya, penelitian selanjutnya dapat menambah variabel independen lain seperti: kepemilikan asing, besarnya perusahaan dan exchange rate.

2. Penelitian selanjutnya diharapkan dapat memperluas populasi yang digunakan dengan menambahkan sektor lain yang terdaftar di Bursa Efek Indonesia dengan maksud untuk mengetahui apakah faktor faktor yang mempengaruhi transfer pricing dapat dilihat pada sektor lainnya. Selain itu pula penelitian selanjutnya dapat menambahkan periode penelitian sehingga penelitian dapat dijelaskan lebih luas lagi.

3. Peneliti selanjutnya diharapkan dapat mencari literatur-literatur yang terkait dengan variabel penelitian dengan lebih baik lagi sebelum memulai penelitian.

\section{DAFTAR PUSTAKA}

Ghozali, Imam. 2016. Aplikasi Analisis Multivariate dengan Program IBM SPSS 21 Update PLS Regresi. Semarang: Badan Penerbit Universitas Diponegoro.

Gunadi, 2007. "Pajak Internasional”, Ed. Revisi, Jakarta, LPFEUI.

Harahap, Sofyan Syafri. 2012. Teori Akuntansi, Jakarta: Rajawali Pers.

M. Zain, 2008. Manajemen Perpajakan. Jakarta: Salemba Empat.

Resmi, Siti. 2017. Perpajakan. Jakarta: Salemba Empat

Scott, William R. 2015. Financial Accounting Theory Fifth Edition. Toronto: Prentice Hall

Siti Kurnia Rahayu, 2010. PERPAJAKAN INDONESIA : Konsep dan Aspek Formal, Yogyakarta : Graha Ilmu.

Sugiyono. 2016. Metode Penelitian Kuantitatif, Kualitatif, dan R\&D. Bandung: Alafabeta

Sulistyanto, H. Sri. 2008. Manajemen Laba, Teori dan Model Empiris. Jakarta: Grasindo

Watts, Ross L. dan Jerold L. Zimmerman (1986). Positive Accounting Theory. USA: Prentice-Hall. 


\title{
PENGARUH MEKANISME INTERNAL CORPORATE GOVERNANCE TERHADAP PENGUNGKAPAN CORPORATE SOCIAL RESPONSIBILITY (CSR) PADA PERUSAHAAN MANUFAKTUR YANG TERDAFTAR DI BURSA EFEK INDONESIA TAHUN 2017-2019
}

\author{
Indira Shinta Dewi, SE., MM., Ak \\ indiradewi20@gmail.com
}

\section{Fakultas Ekonomi dan Bisnis - Program Studi Akuntansi Universitas Satya Negara Indonesia}

\begin{abstract}
ABSTRAK
Tujuan penelitian ini untuk mengetahui dan memperoleh bukti empiris tentang pengaruh mekanisme internal corporate governance terhadap pengungkapan Corporate Social Responsibility (CSR) yang terdaftar di Bursa Efek Indonesia tahun 2017-2019. Mekanisme internal corporate governance dikaji melalui komisaris independen dan komite audit. Pengukuran tanggung jawab sosial perusahaan didasarkan pada Global Reporting Initiative (GRI) yang dilihat dari laporan tahunan perusahaan. Sampel yang menjadi objek penelitian ini adalah semua perusahaan manufaktur yang terdaftar di dalam Bursa Efek Indonesia tahun 2017-2019 dengan memenuhi kriteria yang telah ditetapkan. Total sampel penilitian selama tiga tahun pengamatan adalah 211 sampel, dengan menggunakan metode purposive sampling. Analisis data dilakukan dengan metode regresi linier berganda. Hasil dari penelitian ini menunjukkan bahwa komisaris independen, komite audit, berpengaruh terhadap pengungkapan corporate social responsibility.

Kata kunci : Komisaris Independen, Komite Audit dan Corporate Social Responsibility.
\end{abstract}




\section{PENDAHULUAN}

Pemerintah mengeluarkan Peraturan No.47 tahun 2012 tentang tanggung jawab sosial dan lingkungan perseroan terbatas yang merupakan tindak lanjut dari penjelasan UU No. 40 tahun 2007. Peraturan ini menjadi acuan bagi perusahaan untuk bertanggung jawab terhadap masyarakat dan lingkungan sehingga dapat terpelihara kesinambungan usaha dalam jangka panjang dan mendapat pengakuan sebagai good corporate citizen.

Mekanisme corporate governance dapat mengurangi konflik yang terjadi antara agent dan principal. Corporate governance dianggap mampu mengurangi masalah keagenan karena dengan adanya pengawasan dapat mengurangi perilaku oportunis manajer dan kecenderungan untuk menyembunyikan informasi demi keuntungan pribadi. Menurut Ujiyanto dan Bambang, 2007 corporate governance diarahkan untuk mengurangi asimetri informasi antara principal dan agent.

Corporate governance merupakan konsep untuk meningkatkan efisiensi ekonomis yaitu hubungan antara manajemen perusahaan, dewan direksi, para pemegang saham dan pemangku kepentingan perusahaan lainnya. Corporate governance dapat memberikan suatu sarana memonitoring perusahaan

Menurut Gillan (2006) dan Rezaee (2007) mekanisme corporate governance dapat dibedakan menjadi mekanisme internal dan mekanisme eksternal. Mekanisme internal corporate governance dapat berasal dari dewan komisaris dan komisaris independent.

Penelitian ini ingin menguji mekanisme internal corporate governance yang diproksikan dengan komisaris independent dan komite audit. Keberadaan komisaris independent sangat diperlukan untuk memberikan pengawasan dan memberikan nasihat kepada para direktur secara efektif. Dengan adanya komisaris independen diharapkan dapat mengurangi aktivitas yang menyimpang. Sehingga dengan adanya pengontrolan ini operasional perusahaan akan berjalan dengan baik sehingga dapat meningkatkan kinerja suatu perusahaan yang akhirnya diharapkan dapat memberikan tanggung jawab sosialnya terhadap publik. Menurut penelitian Andina dan Marosono (2014) bahwa komisaris independen tidak berpengaruh terhadap pengungkapan CSR, hasil tersebut didukung oleh penelitian Grand dan Wahyu (2015). Tetapi menurut penelitian Ditta dan Indira (2015) menyatakan bahwa komisaris independen berpengaruh terhadap pengungkapan CSR.

Komite audit juga adalah salah satu mekanisme internal corporate governance. Merupakan bagian dalam perusahaan yang membantu dewan komisaris memastikan bahwa perusahaan telah dijalankan sesuai dengan peraturan yang berlaku, melaksanakan usahanya dengan beretika dan melaksanakan pengawasan secara efektif. Pengawasan membuat perusahaan selalu berusaha meningkatkan kinerjanya dengan baik Berdasarkan tugas tersebut, keberadaan komite audit dapat dianggap sebagai indikator pengawasan kualitas tinggi yang dapat berpengaruh dalam menyediakan informasi lebih kepada pemakai laporan keuangan. Perusahaan dengan kinerja yang baik dapat melaksanakan tanggungjawabnya terhadap lingkungannya. Menurut penelitian Dwi dan Zulaikha (2013) bahwa komite audit tidak berpengaruh terhadap pengungkapan CSR, hasil tersebut didukung oleh penelitian Andina dan Marsono (2014). Tetapi menurut penelitian Grand dan Wahyu (2015) bahwa komite audit berpengaruh terhadap pengungkapan CSR. 
Menurut Riset Centre for Governance, Institutions, and Organizations National University of Singapore (NUS) Business School tahun 2016, memaparkan rendahnya pemahaman perusahaan terhadap praktik CSR. Riset itu melakukan studi terhadap 100 perusahaan di 4 negara yakni Indonesia, Malaysia, Singapura dan Thailand. Indonesia dan Malaysia masing-masing mendaparkan nilai 48,4 dan 47,7 yang terrgolong masih rendah disbanding Thaildan dan Singapore. Kriteria penilaian kualitas tersebut diambil berdasarkan sejumlah indikator dari kerangka Global Rerporting Initiative (GRI). (ww.cnnindonesia.com. ) Hal ini menunjukkan pelaporan CSR di Indonesia yang tidak berkelanjutan. CSR yang berkelanjutan merupakan penilaian akan corporate governance. Namun penelitian ini ingin mendapatkan bukti empiris bagaimana perusahaan manufaktur di Indonesia melalui mekanisme internal corporate nya dapat mengungkapkan CSR

Berdasarkan hal-hal diatas peneliti akan melakukan penelitian dengan judul

"PENGARUH MEKANISME INTERNAL CORPORATE GOVERNANCE TERHADAP PENGUNGKAPAN CORPORATE SOCIAL RESPONSIBILITY (CSR) PADA PERUSAHAAN MANUFAKTUR YANG TERDAFTAR DI BURSA EFEK INDONESIA TAHUN 2017-2019."

\section{Perumusan Masalah}

Berdasarkan latar belakang diatas, maka dapat dirumuskan permasalahan sebagai berikut :

1. Apakah mekanisme internal corporate governance yang diproksikan dengan komisaris independen berpengaruh terhadap pengungkapan corporate social responsibility?

2. Apakah mekanisme internal corporate governance yang diproksikan dengan komite audit berpengaruh terhadap pengungkapan corporate social responsibility?

\section{Tujuan Penelitian}

Berdasarkan rumusan masalah diatas, tujuan dari penelitian ini adalah :

a. Mendapatkan bukti empiris mekanisme internal corporate governance yang diproksikan dengan komisaris independen berpengaruh terhadap pengungkapan corporate social responsibility?

b. Mendapatkan bukti empiris mekanisme internal corporate governance yang diproksikan dengan komite audit berpengaruh terhadap pengungkapan corporate social responsibility?

\section{Manfaat Penelitian}

Penelitian ini diharapkan dapat memberikan manfaat kepada :

1. Pengembangan teori. Penelitian ini berkontribusi pada pengembangan teori agensi yang berhubungan dengan pengungkapan CSR

2. Perusahaan. Penelitian ini berkontribusi pada perusahaan go public yang melakukan pengungkapan corporate social responsibility 


\section{LANDASAN TEORI}

\section{Teori Agensi}

Menurut Jensen and Meckling 1976 teori agensi merupakan konflik yang akan terjadi antara pemilik perusahaan dan manajemen perusahaan. Konflik terjadi karena adanya perbedaan kepentingan antara pemilik dengan manajemen perusahaan. Setiap pihak berusaha untuk mencapai atau mempertahankan tingkat kemakmuran yang dikehendakinya

Teori agensi digunakan untuk mempermudah memahami Good Corporate Governance. Menurut Sumartha (2016) teori ini dijelaskan bahwa : Manajemen yang berperan sebagai agent atau pihak yang diberi tugas untuk mengelola perusahaan dengan baik, sedangkan pemegang saham berperan sebagai principal atau pihak yang melakukan kontrol terhadap kinerja manajemen pada perusahaan yang bersangkutan. Kebijakan pembagian dividen ini menjadi tugas manajemen untuk mengelola perusahaan dengan baik sehingga perusahaan dapat memaksimalkan keuntungan dan mampu membayar dividen kepada para pemegang saham.

Dwi dan Zulaikha (2013) menyatakan bahwa biaya agensi yang muncul karena konflik kepentingan antara agent dan principal dapat dikurangi dengan mekanisme pengawasan yang dapat menyelaraskan berbagai kepentingan yang ada dalam perusahaan. Mekanisme pengawasan yang dimaksud adalah mekanisme Good Corporate Governance (GCG). GCG dianggap mampu mengurangi masalah keagenan karena dengan adanya pengawasan maka perilaku oportunis manajer dan kecenderungan untuk menyembunyikan informasi demi keuntungan pribadi dan dapat mengarah pada peningkatan pengungkapan perusahaan.

\section{Definisi Corporate Governance}

Menurut Forum for Corporate Governance In Indonesia (FGGI 2001) Corporate governance merupakan salah satu konsep yang dapat dipergumakan dalam meningkatkan efisiensi ekonomis, yang meliputi serangkaian hubungan anatra dewan direksi, manajemen perusahaan, para pemegang saham dan pemangku kepentingan perusahaan lainnya. Corporate Governance merupakan suatu struktur untuk penentuan sasaran-sasaran dari suatu perusahaan, sarana untuk menentukan Teknik monitoring kerja.

Watts (2003) menyatakan bahwa corporate governance merupakan salah satu cara yang digunakan untuk memonitor masalah kontrak dan membatasi perilaku opportunistic manajemen .

Corporate governance dapat meminimalisir asimetri informasi antara principal dan agent yang dapat menurunkan tindakan manajemen laba(Ujiyanto dan Bambang,2007)

Forum for Corporate Governance In Indonesia (FGGI 2001) menggunakan definisi Cadbury Committee, Sistem yang mengatur hubungan antara pengurus (pengelola) perusahaan, pemegang saham, pemerintah, pihak kreditur , karyawan serta para pemegang kepentingan intern dan ekstern lainnya yang berkaitan dengan hak-hak dan kewajiban mereka, atau dengan kata lain suatu system yang mengatur, mengontrol dan mengendalikan perusahaan. Corporate governance yang baik ( good corporate governance / GCG) merupakan kunci sukses perusahaan dalam mengelola perusahaan yang berdampak pada laporan keuangan yang dihasilkan 
lebih terjamin kualitasnya. Perusahaan yang mempunyai tata kelola yang baik menunjukkan manajemen perusahaan sehat. Hal ini dapat menekan aktivitas perekayasaan kinerja yang mengakibatkan laporan keuangan menggambarkan nilai yang sesungguhnya.

Menurut Franita (2018:10) bahwa good corporate governance merupakan suatu sistem yang mengelola dan mengawasi proses pengendalian usaha yang berjalan secara berkesinambungan untuk menaikkan nilai saham, yang akhirnya akan meningkatkan nilai perusahaan dan sebagai bentuk pertanggungjawaban kepada shareholders tanpa mengabaikan kepentingan stakeholders yang meliputi kreditur, karyawan, dan masyarakat.

Dari definisi diatas dapat disimpulkan bahwa Corporate Governance adalah sistem atau seperangkat peraturan yang mengatur, mengelola, dan mengawasi hubungan antara para pengelola perusahaan dengan stakeholders disuatu perusahaan.

Menurut Komite Nasional Kebijakan Governance (KNKG) dalam Pedoman Umum Good Corporate Governance Indonesia (2006), mempunyai prinsip yaitu prinsip transparency, accountability, responsibility, independency, fairness

\section{Manfaat Penerapan Corporate Governance Bagi Perusahaan}

Menurut Handoko (2017) penerapan Corporate Governance perlu didukung oleh tiga pilar yang saling berhubungan yaitu negara dan perangkatnya sebagai regulator, dunia usaha sebagai pelaku pasar dan masyarakat sebagai pengguna jasa dan produk. Prinsip-prinsip dasar yang harus dilakukan oleh masing-masing pilar adalah : pertama negara dan perangkatnya menciptakan undang-undang yang menunjang iklim usaha yang sehat, efisien dan transparan, melaksanakan peraturan perundang-undangan dan penegakan hukum secara konsisten. Kedua, dunia usaha sebagai pelaku pasar menerapkan Corporate Governance sebagai pedoman dasar pelaksanaan usaha. Ketiga, masyarakat sebagai pengguna produk dan jasa dunia usaha serta pihak yang terkena dampak dari keberadaan perusahaan, menunjukkan kepedulian dan melakukan kontrol sosial serta objektif dan bertangung jawab.

\section{Komisaris Independen}

Agus (2020) menyatakan bahwa komisaris independen memiliki tanggung jawab pokok untuk mendorong diterapkannya prinsip tata kelola perusahaan yang baik (good corporate governance). Hal itu dilakukan dengan cara mendorong anggota dewan komisaris yang lain agar dapat melakukan tugas pengawasan dan pemberian nasihat kepada para direktur secara efektif dan dapat memberikan nilai tambah bagi perusahaan

Sjawie (2017:131) menyatakan bahwa komisaris independen adalah orang yang diangkat RUPS (Rapat Umum Pemegang Saham) sebagai anggota dewan komisaris, yang tidak terafiliasi dengan pemegang saham utama, anggota direksi dan/atau dewan komisaris lain.

Menurut Ikatan Bankir Indonesia (2018:248) komisaris independen adalah Anggota dewan komisaris yang tidak memiliki hubungan keuangan, kepengurusan, kepemilikan saham dan/atau hubungan keluarga dengan anggota direksi, anggota dewan komisaris lain dan/atau pemegang saham pengendali atau hubungan dengan Bank yang dapat mempengaruhi kemampuan yang bersangkutan untuk bertindak independen. 
Menurut Samsul (2006:72) komisaris independen adalah anggota komisaris yang tidak mempunyai hubungan afiliasi dengan anggota komisaris lainnya, anggota dewan direksi, dan pemegang saham pengendali. Komisaris independen juga dapat merangkap sebagai ketua komite audit.

Dalam rangka penerapan Corporate Governance keberadaan komisaris independen sangat diperlukan. Secara langsung keberadaan komisaris independen menjadi penting, karena didalam praktek sering ditemukan transaksi yang mengandung benturan kepentingan mengabaikan kepentingan pemegang saham minoritas dan kepentingan para stakeholder lainnya, terutama pada perusahaan di Indonesia yang menggunakan dana masyarakat didalam pembiayaan usahanya (Utami, 2016).

Menurut Mirza (2015) Dewan komisaris independen yang netral dan tidak terpengaruh oleh intervensi manajemen akan melindungi kepentingan para stakeholder.

Menurut Said et. al (2009) menjelaskan bahwa independensi atau proporsi komisaris independen tidak dapat berpengaruh terhadap luas pengungkapan CSR perusahaan. Dengan demikian keberadaan atau proporsi komisaris independen tidak dapat mempengaruhi proses pengambilan keputusan dikarenakan mereka tidak mempunyai hubungan dengan aktivitas atau operasi sehari-hari perusahaan.

Alasan yang dapat menjelaskan hal ini adalah dimungkinkan karena pemilihan dan pengangkatan komisaris independen yang kurang efektif. Hal ini merupakan isu atau hal yang penting, bahwa banyak anggota komisaris independen tidak memiliki kemampuan, dan tidak dapat menunjukkan independensinya atau sebenarnya tidak independent, sehingga fungsi pengawasan tidak dapat berjalan dengan baik (Waryanto, 2010).

Komisaris independen dapat dihitung dengan cara berikut :

$$
\text { Komisaris Independen }=\frac{\sum \begin{array}{c}
\text { anggota komisaris } \\
\text { independen }
\end{array}}{\sum \begin{array}{c}
\text { seluruh anggota dewan } \\
\text { komisaris }
\end{array}}
$$

Rumus ini digunakan untuk mencari jumlah anggota komisaris independen. Menurut POJK Nomor 33/POJK.04/2014 jumlah komisaris independen yang dimiliki sekurang-kurangnya $30 \%$ dari jumlah seluruh anggota komisaris, berarti telah memenuhi pedoman GCG guna menjaga independensi, pengambilan keputusan yang efektif, tepat, dan cepat.

\section{Komite Audit}

Menurut Franita (2018:13) menyatakan bahwa komite audit adalah suatu komite yang sedikitnya terdiri dari tiga orang, diketuai oleh komisaris independen perusahaan dengan dua orang eksternal yang independen terhadap perusahaan serta menguasai dan memiliki latar belakang akuntansi dan keuangan.

Komite audit merupakan komite yang dibentuk oleh dewan komisaris, yang bertugas untuk membantu dewan komisaris dalam melaksanakan tugasnya (Andina dan Marsono, 2014).

Menurut Samsul (2006:72) komite audit adalah :

Komite yang dibentuk oleh dewan komisaris perusahaan tercatat, yang anggotanya diangkat dan diberhentikan oleh dewan komisaris untuk membantu 
melakukan pemeriksaan atau penelitian yang dianggap perlu terhadap pelaksanaan fungsi direksi dalam mengelola perusahaan tercatat.

Menurut Komite Nasional Kebijakan Governance (KNKG) dalam Pedoman Umum good corporate Indonesia (2006) dijelaskan bahwa, komite audit bertugas membantu dewan komisaris untuk memastikan bahwa: (i) laporan keuangan disajikan secara wajar sesuai dengan prinsip akuntansi yang berlaku umum, (ii) struktur pengendalian internal perusahaan dilaksanakan dengan baik, (iii) pelaksanaan audit internal maupun eksternal dilaksanakan sesuai dengan standar audit yang berlaku, dan (iv) tindak lanjut temuan hasil audit dilaksanakan oleh manajemen.

Komite audit merupakan unsur penting dalam mewujudkan penerapan corporate governance. Keberadaan komite audit dapat membantu dewan komisaris meningkatkan pengawasan terhadap manajemen perusahaan, sehingga hal ini dapat menjadi usaha perbaikan tata cara pengelolaan perusahaan karena komite audit akan menjadi hubungan antara manajemen perusahaan dengan dewan komisaris maupun pihak eksternal lainnya (Rahmawati, 2010).

Dalam penelitian ini rumus yang digunakan untuk mencari komite audit adalah :

$$
\text { Komite Audit }=\sum \text { komite audit }
$$

Rumus ini digunakan untuk mencari jumlah anggota komite audit. Menurut Peraturan BAPEPAM Nomor: KEP-643/BL/2012 keanggotaan komite audit sekurang-kurangnya terdiri dari 3 orang, dimana seorang diantaranya merupakan komisaris independen yang sekaligus merangkap sebagai ketua komite audit dan pihak dari luar emiten atau perusahaan publik.

\section{Corporate Social Responsibility}

CSR adalah cara perusahaan mencapai keseimbangan atau integrasi dari environment atau lingkungan, ekonomi, dan persoalan-persoalan social dalam waktu yang sama bisa memenuhi harapan dari shareholder maupun stakeholders (Edi Suharto,2006:5)

CSR merupakan suatu tindakan yang dilakukan perusahaan sesuai dengan kemampuan perusahaan sebagai bentuk tanggung jawab terhadap masyarakat dan lingkungan disekitar perusahaan itu berada (Nurwahidah, 2016).

Menurut Yusuf (2017:29) Corporate Social Responsibility adalah :Suatu bentuk tanggung jawab social perusahaan terhadap masyarakat disekitarnya yang merupakan serangkaian kegiatan aktif perusahaan di tengah-tengah masyarakat dan semua pemegang yang berkepentingan dalam rangka pengembangan kualitas kearah yang lebih baik dalam berbagai dimensi kehidupan.

Dari definisi-definisi diatas dapat disimpulkan bahwa CSR merupakan sebuah tindakan atau konsep sosial yang dilakukan oleh sebuah perusahaan untuk membantu kehidupan termasuk didalamnya lingkungan, ekonomi, dan kesejahteraan masyarakat.

\section{Pengungkapan Corporate Social Responsibility}

Pengungkapan tanggung jawab sosial atau sering disebut sebagai corporate social reporting adalah proses pengkomunikasian efek-efek sosial dan lingkungan 
atas tindakan-tindakan ekonomi perusahaan pada kelompok-kelompok tertentu dalam masyarakat dan pada masyarakat secara keseluruhan (Gray et. Al., 1987 dalam Waryanto 2010).

Di Indonesia praktik pengungkapan tanggung jawab sosial diatur oleh Ikatan Akuntan Indonesia (IAI) yang tertuang dalam Pernyataan Standar Akuntansi Keuangan (PSAK) No.1 Paragraf 9, yang menyatakan bahwa perusahaan dapat pula menyajikan laporan tambahan seperti laporan mengenai lingkungan hidup dan laporan nilai tambah (value added statement), khususnya bagi industri dimana faktor-faktor lingkungan hidup memegang peranan penting dan bagi industri yang menganggap pegawai sebagai kelompok pengguna laporan yang memegang peranan penting.

Selain itu, pengungkapan tanggung jawab sosial juga terdapat dalam Peraturan Pemerintah No.47 tahun 2012 tentang Tanggung Jawab Sosial dan Lingkungan Perseroan Terbatas Pasal 3 ayat (1) menyebutkan bahwa tanggung jawab sosial dan lingkungan menjadi kewajiban bagi perseroan yang menjalankan kegiatan usahanya di bidang dan/atau berkaitan dengan sumber daya alam berdasarkan Undang-Undang.

\section{Prinsip-Prinsip Corporate Social Responsibility}

Menurut Crowther dan Aras (2008:14-16) mengemukakan prinsip-prinsip corporate social responsibility, yaitu :

Prinsip pertama adalah kesinambungan atau sustainability. Sustainability berkaitan dengan cara perusahaan dalam melakukan kegiatan dengan tetap menghitung keberlanjutan sumber daya di masa mendatang. Keberlanjutan ini juga dapat memberikan arahan penggunaan sumber daya saat ini dengan tetap memperhatikan dan memperhitungkan kemampuan generasi mendatang dengan kata lain program yang dirancang harus memiliki dampak yang berkelanjutan.

Prinsip kedua adalah accountability. Accountability adalah upaya perusahaan untuk terbuka dan bertanggung jawab atas kegiatan yang mereka lakukan. Akuntanbilitas ini sangat diperlukan untuk kegiatan perusahaan yang dapat mempengaruhi atau dipengaruhi oleh lingkungan eksternal. Akuntanbilitas perusahaan ini dapat dijadikan sebagai sarana bagi perusahaan untuk meningkatkan image dan jaringan dengan pihak-pihak yang berkepentingan dengan menunjukkan tingkat keluasan dan informasi laporan perusahaan memiliki konsekuensi social atau ekonomi.

Prinsip ketiga adalah transparency. Transparancy merupakan bagi pihakpihak eksternal terutama transaksi yang terkait dengan pelaporan kegiatan perusahaan yang dapat berdampak pada pihak eksternal.

\section{Kerangka Pemikiran}

Praktik pengungkapan corporate social responsibility beraperan penting dalam perusahaan karena perusahaan beroperasi dilingkungan masyarakat dan aktivitasnya memiliki dampak bagi sekitarnya. Dengan adanya pengungkapan corporate social responsibility yang baik pada perusahaan maka stakeholders akan makin puas dan akan memberikan dukungan penuh kepada perusahaan atas segala aktivitasnya yang bertujuan menaikkan kinerja. Pengungkapan corporate social responsibility dapat dilakukan jika perusahaan sudah menerapkan corporate governance. Corporate governance juga dapat diterapkan untuk mengatasi masalah 
agency perusahaan. Corporate governance (tata kelola perusahaan) dapat dianggap mampu mengurangi masalah karena dengan adanya pengawasan dapat mengurangi terjadinya kecurangan manajemen demi kepentingan pribadi.

Mekanisme internal corporate governance menjadi focus pada penelitian ini, penelitian ini ingin menguji mekanisme internal corporate governance yang diproksikan dengan komisaris independent dan komite audit

Komisaris independen sebagai salah satu mekanisme internal corporate governance sangat diperlukan karena dengan adanya pengawasan terhadap kepatuhan perusahaan pada perundangan dan peraturan yang berlaku dan memberikan nasihat kepada para direktur secara efektif dapat memberikan nilai tambah bagi perusahaan. Dengan demikian perusahaan berusaha untuk meningkatkan kinerjanya yang akhirnya akan melakukan pengungkapan tanggungjawab social yang berguna untuk meningkatkan citra perusahaan dimata publik

Selain komisaris independent, komite audit juga merupakan salah satu mekanisme internal corporate governance. Salah satu fungsi komite audit sebagai bagian dalam perusahaan adalah membantu dewan komisaris memastikan bahwa perusahaan telah dijalankan sesuai dengan peraturan yang berlaku, melaksanakan usahanya dengan beretika dan melaksanakan pengawasan secara efektif. Berdasarkan tugas tersebut, keberadaan komite audit dapat dianggap sebagai indikator pengawasan kualitas tinggi yang dapat berpengaruh dalam menyediakan informasi lebih kepada pemakai laporan keuangan. Maka komite audit akan memberikan dampak peningkatan kinerja perusahaan yang akhirnya akan ada pengungkapan CSR.

Dapat disimpulkan bahwa komisaris independent dan komite audit merupakan mekanisme internal perusahaan, keduanya memberikan pengawasan terhadap perusahaan dengan masing-masing tugasnya yang berbeda. Pengawasan tersebut mempunyai dampak terhadap manajemen perusahaan untuk berusaha meningkatkan kinerja keuangannya dengan tetap mematuhi aturan perusahaan dan pemerintah. Peningkatan kinerja keuangan akan mendorong perusahaan untuk melakukan tanggungjawab sosialnya.

\section{METODOLOGI PENELITIAN}

\section{Waktu Penelitian}

Penelitian ini dilaksanakan selama empat bulan yaitu mulai bulan April sampai dengan bulan Juli 2020.

\section{Tempat Penelitian}

Penelitian ini dilaksanakan dengan mengambil data laporan keuangan tahunan perusahaan manufaktur yang terdaftar di Bursa Efek Indonesia dengan mengakses situs resmi BEI, yaitu http://www.idx.co.id

\section{Populasi}

Populasi adalah kejadian atau segala sesuatu yang memiliki karakteristik tertentu. Populasi juga dapat diartikan sebagai ojek atau subjek yang mempunyai kualitas dan karakteristik tertentu yang diterapkan oleh peneliti untuk dipelajari dan kemudian ditarik kesimpulannya. Populasi yang akan menjadi objek dalam penelitian ini adalah seluruh perusahaan manufaktur yang terdaftar di Bursa Efek Indonesia (BEI) periode 2017-2019. 


\section{Sampel}

\section{Metode Pengambilan Sampel}

Metode pengambilan sampel yang digunakan dalam penelitian ini adalah teknik purposive sampling, yaitu pengambilan sampel dari target spesifik yang akan mampu menyediakan informasi yang diinginkan karena merupakan satu-satunya yang bisa memberikan informasi yang dibutuhkan.

\section{Jenis dan Pengumpulan Data \\ Jenis Data dan Pengumpulan Data}

Data yang digunakan dalam penelitian ini adalah data sekunder. Data sekunder adalah data dari perusahaan yang telah siap di olah sesuai dengan kebutuhan pemakai informasi. Pada penelitian ini, data yang digunakan adalah laporan keuangan perusahaan manufaktur yang terdaftar di Bursa Efek Indonesia (BEI) Periode 2017-2019, dimana datanya lebih terpercaya keabsahannya karena telah diperiksa oleh akuntan independen.

Adapun cara pengumpulan data penelitian ini adalah sebagai berikut :

1. Metode Penelitian Lapangan (Field Research)

2. Metode Penelitian Kepustakaan (Library Research) adalah data sekunder, lain terkait dengan pembahasan masalah penelitian yang dibutuhkan.

\section{Variabel Penelitian}

\section{Variabel Dependen (Y)}

Variabel dependen adalah variabel yang dipengaruhi oleh variabel independen. Variabel dependen dalam penelitian ini adalah corporate social responsibility.

\section{Variabrel Independen $(\mathrm{X})$}

Variabel-variabel independen (X) atau variabel bebas adalah variabel yang dipengaruhi variabel lainnya. Variabel independen yang digunakan dalam penelitian ini adalah komisaris independen (X1), komite audit (X2).

\section{Design Penelitian}

Desain penelitian yang digunakan dalam penelitian ini adalah penelitian kausal. Penelitian kausal merupakan penelitian untuk mengetahui pengaruh antara satu atau lebih variable bebas terhadap variable terikat.

Adapun kerangka penelitian ini dapat digambarkan sebagai berikut :

Variabel Independen

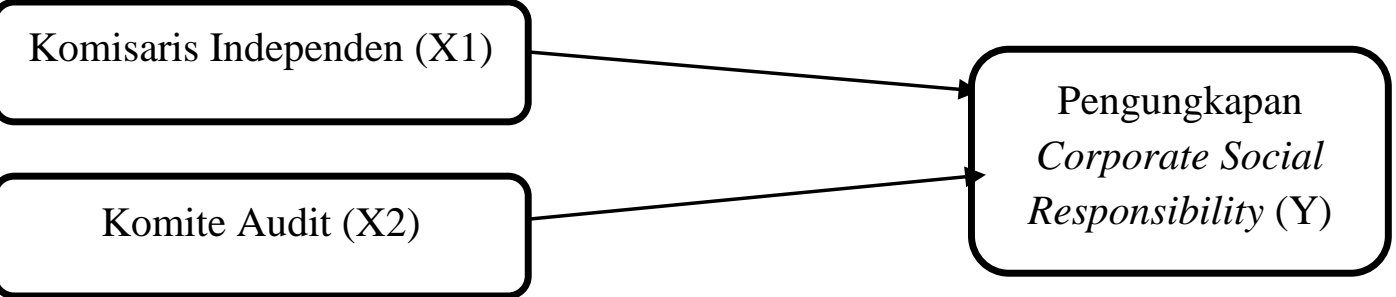

Variabel Dependen

Gambar 3.1 Desain Penelitian 


\section{Hipotesis}

Pengujian hipotesis bertujuan untuk mengetahui pengaruh mekanisme internal corporate governance terhadap pengungkapan Corporate Social Responsibility yang akan diuji dalam penelitian ini sebagai berikut :

$\mathrm{HO}_{1}$ : Komisaris independen tidak berpengaruh terhadap pengungkapan CSR.

$\mathrm{HO}_{2}$ : Komite audit tidak berpengaruh terhadap pengungkapan CSR.

\section{Variabel penelitian}

Dalam penelitian ini terdapat lima variable yaitu empat variable bebas (independent variable) dan satu variable terikat (dependent variable), yaitu:

1. Variabel bebas atau independen variabel (X) merupakan variabel yang dapat mempengaruhi atau menjadi sebab perubahan atau timbulnya dependen variabel atau variabel terikat (Y). Dalam penelitian ini yang menjadi " $\mathrm{X}$ " adalah Komisaris Independen (X1), Komite Audit (X2).

2. Variabel terikat atau dependent variabel (Y) merupakan variabel yang dipengaruhi atau yang menjadi akibat karena adanya independent variabel atau variabel bebas $(\mathrm{X})$. Dalam penelitian ini yang menjadi variabel "Y" adalah Pengungkapan Corporate Social Responsibility.

\section{ANALISIS HASIL DAN PEMBAHASAN \\ Analisis Deskriptif \\ Tabel 4.2 \\ Statistik Deskriptif \\ Descriptive Statistics}

\begin{tabular}{|l|r|r|r|r|r|}
\hline & $\mathrm{N}$ & $\begin{array}{r}\text { Minimu } \\
\mathrm{m}\end{array}$ & $\begin{array}{r}\text { Maximu } \\
\mathrm{m}\end{array}$ & Mean & \multicolumn{1}{c|}{$\begin{array}{c}\text { Std. } \\
\text { Deviation }\end{array}$} \\
\hline $\begin{array}{l}\text { Komisaris } \\
\text { Independen } \\
\text { Komite Audit }\end{array}$ & 211 & .16 & .67 & .4054 & .09955 \\
$\begin{array}{l}\text { Pengungkapan } \\
\text { Corporate Social } \\
\text { Responsibility } \\
\text { Valid N (listwise) }\end{array}$ & 211 & 1 & 5 & 3.05 & .450 \\
\hline
\end{tabular}

Sumber : Output SPSS

Hasil analisa deskriptif memperlihatkan bahwa jumlah sampel 211. Nilai minimum komisaris independen 0,16 , nilai maximum 0,67 , nilai mean 0,4054 dan standar deviasi 0,09955 , nilai minimum komite audit 1 , nilai maximum 5 , nilai mean 3,05 dan standar deviasi 0,450 , nilai minimum pengungkapan corporate social responsibility 0,01 , nilai maximum 0,34 , nilai mean 0,0843 dan standar deviasi 0,06480 .

\section{Analisis Statistik}

Analisis data statistik bertujuan untuk membuktikan kebenaran hipotesis yang diajukan maka digunakan regresi linier berganda. Beberapa tahapan yang 
digunakan yang digunakan sebelum melakukan uji regresi linier berganda diperlukan uji asumsi klasik terlebih dahulu.

\section{Uji Asumsi Klasik}

\section{Uji Normalitas}

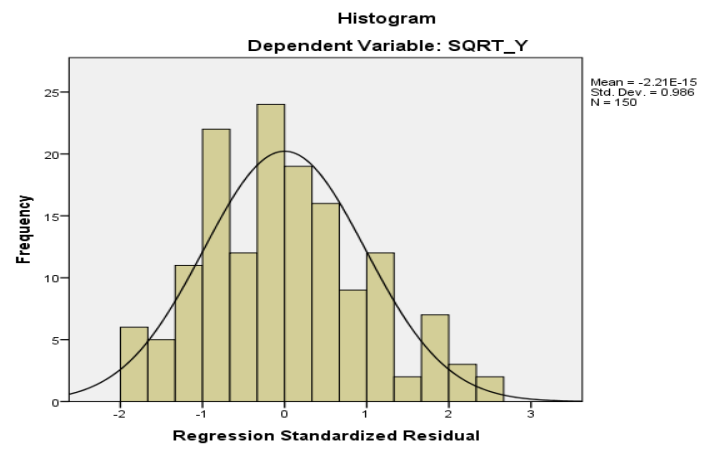

Sumber : Output SPSS

\section{Gambar 4.1 Histogram}

Berdasarkan tampilan grafik histogram diatas menunjukkan pola distribusi normal karena distribusi data tersebut tidak menceng ke kanan maupun menceng ke kiri.

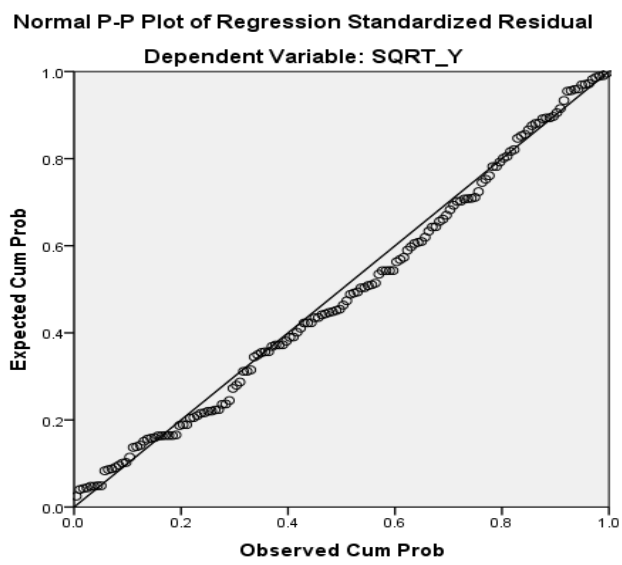

Sumber : Output SPSS

Gambar 4.2 P-P Plot

Berdasarkan pada gambar 4.2 terlihat titik-titik mengikuti dan mendekati garis diagonalnya sehingga dapat disimpulkan bahwa model regresi memenuhi uji normalitas.

Tabel 4.3

Hasil Uji One Sample Kolmogorov Smirnov

One-Sample Kolmogorov-Smirnov Test

\begin{tabular}{|ll|r|}
\hline & & \multicolumn{1}{|c|}{$\begin{array}{c}\text { Unstandardize } \\
\text { d Residual }\end{array}$} \\
\hline $\mathrm{N}$ & & 211 \\
Normal Parameters ${ }^{\mathrm{a}, \mathrm{b}}$ & Mean & .0000000 \\
& Std. Deviation & .10394728 \\
\hline
\end{tabular}




\begin{tabular}{|ll|r|} 
Most Extreme Differences & Absolute & .057 \\
& Positive & .057 \\
& Negative & -.037 \\
Test Statistic & & .057 \\
Asymp. Sig. (2-tailed) & & $.200^{\mathrm{c}, \mathrm{d}}$ \\
\hline
\end{tabular}

a. Test distribution is Normal.

b. Calculated from data.

c. Lilliefors Significance Correction.

d. This is a lower bound of the true significance.

Sumber : Output SPSS

Hasil uji normalitas dengan One Sample Kolmogorov Smirnov diperoleh nilai signifikan sebesar 0,200 dengan demikian dapat dikatakan nilai signifikan diatas 0,05 sehingga data dinyatakan normal.

\section{Uji Multikolonieritas}

Model regresi yang baik adalah model regresi yang tidak terjadi korelasi diantara variabel bebas. Dapat diketahui dengan melihat nilai Variance Inflation Factor (VIF) jika VIF kurang dari 10 dan Tolerance lebih dari 0,1 maka dinyatakan tidak terjadi multikolinieritas.

\section{Tabel 4.4}

Hasil Uji Multikolonieritas Coefficients $^{\mathbf{a}}$

\begin{tabular}{|ll|r|r|}
\hline \multirow{2}{*}{ Model } & & \multicolumn{2}{|c|}{ Collinearity Statistics } \\
\cline { 3 - 4 } & & \multicolumn{2}{|c|}{ Tolerance } \\
\hline 1 & Komisaris & .938 & 1.066 \\
& Independen & .896 & 1.116 \\
\hline
\end{tabular}

a. Dependent Variable: CSR Sumber : Output SPSS

Berdasarkan tabel diatas, diperoleh VIF untuk variabel X1 komisaris independen sebesar 1,066, X2 komite audit sebesar 1,116, sehingga menunjukkan bahwa tidak terdapat multikolonieritas karena VIF $<10$ dan tolerance $>0,1$.

\section{Uji Heteroskedastisitas}

Model regrasi yang baik seharusnya tidak terjadi heteroskedastisitas. Uji heteroskedastisitas bisa dengan melihat pola titik-titik pada grafik regresi. Jika tidak ada pola yang jelas, seperti titik-titik menyebar di atas dan dibawah angka 0 pada sumbu Y, maka tidak terjadi heteroskedastisitas. Berikut grafik yang menunjukkan bahwa model regresi pada penelitian ini bebas dari gangguan heterokedastisitas. 


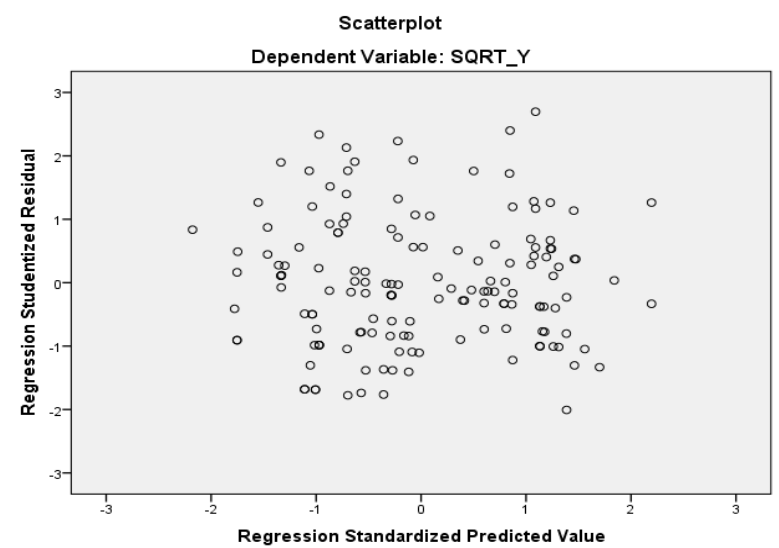

\section{Sumber : Output SPSS}

\section{Gambar 4.3 Grafik Scatterplot}

Dilihat dari grafik scatterplot pada gambar 4.3, menunjukkan bahwa tidak ada pola tertentu karena titik menyebar tidak beraturan diatas dan dibawah sumbu 0 pada sumbu Y maka dapat disimpulkan tidak terjadi heteroskedastisitas. Grafik scatterplot didukung dengan uji glejser. Berikut hasil uji glejser

\section{Tabel 4.5}

\section{Hasil Uji Glejser}

Coefficients $^{\mathbf{a}}$

\begin{tabular}{|c|c|c|c|c|c|c|}
\hline \multirow{2}{*}{\multicolumn{2}{|c|}{ Model }} & \multicolumn{2}{|c|}{$\begin{array}{l}\text { Unstandardized } \\
\text { Coefficients }\end{array}$} & \multirow{2}{*}{$\begin{array}{c}\begin{array}{c}\text { Standardize } \\
\mathrm{d} \\
\text { Coefficients }\end{array} \\
\text { Beta }\end{array}$} & \multirow[b]{2}{*}{$\mathrm{T}$} & \multirow[b]{2}{*}{ Sig. } \\
\hline & & B & Std. Error & & & \\
\hline \multirow[t]{3}{*}{1} & (Constant) & .078 & .076 & & 1.022 & .308 \\
\hline & $\begin{array}{l}\text { Komisaris } \\
\text { Independen }\end{array}$ & .074 & .068 & .091 & 1.073 & .285 \\
\hline & $\begin{array}{l}\text { Komite } \\
\text { audit }\end{array}$ & .005 & .040 & .011 & .123 & .902 \\
\hline
\end{tabular}

a. Dependent Variable: CSR

Sumber : Output SPSS

Berdasarkan table 4.5 dapat dilihat bahwa signifikansi variabel X1 komisaris independen sebesar 0,285, X2 komite audit sebesar 0,902, signifikansi kedua variabel tersebut lebih besar dari 0,05 maka dapat disimpulkan tidak terjadi heteroskedastisitas.

\section{Uji Autokorelasi}

Model regresi yang baik adalah model yang tidak mengandung autokorelasi. uji Durbin Watson (DW - test) digunakan untuk menguji autokorelasi. Nilai uji statistik Durbin-Watson harus menunjukkan nilai 1-2 atau tidak boleh lebih dari tiga . 
Tabel 4.6

Uji Autokorelasi

\begin{tabular}{|l|r|r|r|r|r|}
\hline \multicolumn{7}{|c|}{ Model Summary $^{\mathbf{b}}$} \\
\hline 1 & $\mathrm{R}$ & R Square & Adjusted R Square & $\begin{array}{c}\text { Std. Error of the } \\
\text { Estimate }\end{array}$ & Durbin-Watson \\
\hline & $.697^{\mathrm{a}}$ & .845 & .735 & 1.537 & 1.845 \\
\hline
\end{tabular}

a. Predictors: (Constant), Komisaris Indipenden, Komite audit

b. Dependent Variable: CSR

Sumber : Output SPSS

Berdasarkan tabel uji autokorelasi diatas terlihat bahwa nilai Durbin Watson sebesar 1,845 Ini berarti bahwa model regresi yang digunakan dalam penelitian sudah baik karena nilai Durbin Watson berada diantara nilai 1-2.

\section{Uji Hipotesis}

\section{Koefisien Determinasi $\left(R^{2}\right)$}

Koefisien determinasi $R^{2}$ bertujuan untuk mengukur seberapa jauh kemampuan model dapat menerangkan variasi variabel.

\section{Tabel 4.7}

Hasil Koefisien Determinasi Model Summaryb

\begin{tabular}{|l|l|r|r|r|}
\hline Model & R & R Square & $\begin{array}{c}\text { Adjusted R } \\
\text { Square }\end{array}$ & $\begin{array}{c}\text { Std. Error of } \\
\text { the Estimate }\end{array}$ \\
\hline 1 & $.697^{\mathrm{a}}$ & .845 & .735 & 1.537 \\
\hline
\end{tabular}

a. Predictors: (Constant), Komisaris Independen,Komite audit

b. Dependent Variable:_CSR

Sumber: Output SPSS

Berdasarkan tabel diatas, nilai adjusted $\mathrm{R}$ square sebesar 0,735 . Hal ini menunjukkan bahwa variabel independen dapat menjelaskan variabel dependen sebesar $73,5 \%$ berarti bahwa $26,5 \%$ dipengaruhi oleh variabel lain yang tidak terdapat dalam penelitian ini.

\section{Uji Regresi Linier Berganda}

Tabel 4.8

Hasil Uji Regresi Linier Berganda

Coefficients $^{\mathbf{a}}$

\begin{tabular}{|c|c|c|c|c|c|c|}
\hline \multirow{2}{*}{\multicolumn{2}{|c|}{ Model }} & \multicolumn{2}{|c|}{$\begin{array}{l}\text { Unstandardized } \\
\text { Coefficients }\end{array}$} & \multirow{2}{*}{$\begin{array}{c}\text { Standardized } \\
\text { Coefficients }\end{array}$} & \multirow[b]{2}{*}{$\mathrm{T}$} & \multirow[b]{2}{*}{ Sig. } \\
\hline & & B & Std. Error & & & \\
\hline & (Constant) & 32.284 & 2.129 & & 2.204 & .009 \\
\hline & Komisaris & & & & & \\
\hline & $\begin{array}{l}\text { Indepen } \\
\text { den }\end{array}$ & .332 & .168 & .477. & 2.241 & .035 \\
\hline
\end{tabular}




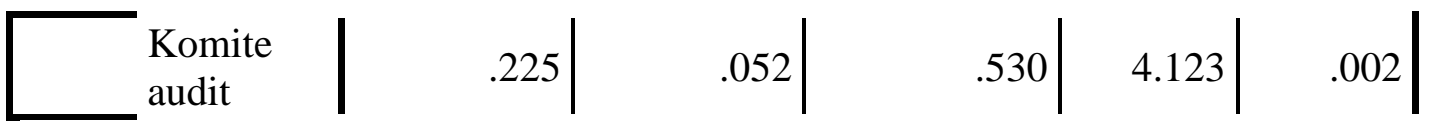

a. Dependent Variable: CSR

Sumber : Output SPSS

Berdasarkan tabel uji regresi linier berganda, maka diperoleh persamaan regresi linier berganda sebagai berikut :

$\mathrm{Y}=32.284+0,332 \mathrm{X}_{1}+0,225 \mathrm{X}_{2}+\mathrm{e}$

Dari persamaan regresi tersebut dapat dijelaskan :

1. Konstanta sebesar 32,284 , artinya apabila variabel $\mathrm{X}$ dianggap konstan atau bernilai 0, maka besar nya Y nilainya 32,284.

2. Koefisien regresi variabel komisaris independen sebesar 0,332, artinya setiap peningkatan komisaris independen sebesar (bernilai 1) satuan, maka pengungkapan CSR akan mengalami peningkatan sebesar 0,332.

3. Koefisien regresi variabel komite audit sebesar 0,225, artinya setiap peningkatan komite audit sebesar (bernilai 1) satuan, maka pengungkapan CSR akan mengalami peningkatan sebesar 0,225.

\section{Interpretasi Penelitian}

Penelitian ini dilakukan untuk menguji pengaruh mekanisme internal corporate governance terhadap pengungkapan corporate social responsibility pada perusahaan manufaktur yang terdaftar di Bursa Efek Indonesia tahun 2017-2019.

Dari hasil penelitian maka dapat diberikan pembahasan sebagai berikut :

1. Mekanisme internal corporate governance yang diproksikan dengan Komisaris Independen Berpengaruh Terhadap Pengungkapan Corporate Social Responsibility.

Berdasarkan hasil uji $\mathrm{t}$, dapat diketahui bahwa komisaris independen memiliki nilai signifikansi $0,035<0,05$. Sehingga hipotesis pertama yang menyatakan bahwa tidak terdapat pengaruh komisaris independen terhadap pengungkapan CSR ditolak. Mekanisme internal corporate governance yang dikaji melalui komisaris independen dalam penelitian ini mempunyai pengaruh terhadap pengungkapan corporate social responsibility

2. Mekanisme internal corporate governance yang diproksikan dengan Komite Audit Berpengaruh Terhadap Pengungkapan Corporate Social Responsibility Berdasarkan hasil uji t, dapat diketahui bahwa komite audit memiliki nilai signifikansi 0,002 <0,05. Sehingga hipotesis kedua menyatakan bahwa tidak terdapat pengaruh komite audit terhadap pengungkapan CSR ditolak.

Hal ini menunjukkan bahwa komite audit berpengaruh terhadap pengungkapan CSR.

\section{KESIMPULAN DAN SARAN}

\section{Kesimpulan}

Berdasarkan hasil penelitian yang diperoleh, maka dapat ditarik kesimpulan sebagai berikut : 
1. Komisaris independen sebagai proksi dari mekanisme internal corporate governance berpengaruh terhadap pengungkapan corporate social responsibility.

2. Komite audit sebagai proksi dari mekanisme internal corporate governance berpengaruh terhadap pengungkapan corporate social responsibility.

\section{Saran}

Berdasarkan hasil penelitian dan kesimpulan yang diperoleh, maka saran yang dapat diberikan oleh peneliti adalah sebagai berikut :

1. Bagi peneliti selanjutnya disarankan menambah variabel independen yang mempengaruhi pengungkapan CSR yang tidak dimasukkan dalam penelitian ini, misalnya kepemilikan manajerial, kepemilikan institutional, dll, guna melihat faktor eksternal corporate governance apakah masih konsisiten dengan hasil penelitian ini.

2. Bagi peneliti selanjutnya disarankan menggunakan sampel selain perusahaan manufaktur, misalnya perusahaan pertambangan karena perusahaan pertambangan memiliki tanggung jawab yang besar untuk pengungkapan CSR, untuk melihat konsisitensi hasil penelitian.

Daftar Buku :

\section{DAFTAR PUSTAKA}

Crowther, D., \& Aras, G. (2008). Corporate Social Responsibility. ApS.

Daeng Naja, H. R. (2004). Manajemen Fit and Proper Test. Yogyakarta: Pustaka Widyatama.

Echdar, S., \& Maryadi. (2019). Business Ethics And Entrepreneurship. Yogyakarta: CV Budi Utama.

Franita, R. (2018). Mekanisme Good Corporate Governance dan Nilai Perusahaan. Medan: Lembaga Penelitian dan Penulisan Ilmiah Aqli.

Ghozali, I. (2016). Aplikasi Analisis Multivariate dengan Program IBM SPSS 23. Semarang: Badan Penerbit Universitas Diponegoro.

Miraza Nurdi Nugroho dan Agung Yulianto. Pengaruh Profiyabilitas dan Mekanisme Corporate Governance Terhadap Pengungkapan CSR perusahaan terdaftar JII 2011-2013

Syairozi, M. I. (2019). Pengungkapan CSR Pada Perusahaan Manufaktur dan Perbankan. Magelang: Tidar Media.

Umar, H. (2003). Business An Introduction. Jakarta: PT. Gramedia Pustaka Utama.

Yusuf, M. Y. (2017). Islamic Corporate Social Responsibility (I-CSR) Pada Lembaga Keuangan Syariah (LKS): Teori dan Pratik. Jakarta: Kencana.

Daftar Jurnal : 
Chen, M. (2019). Pengaruh Ukuran Dewan Komisaris dan Kepemilikan Asing Terhadap Luas Pengungkapan CSR, 2442-8922.

Gilan,S(2006). Recent developments incorporate governance: An overvew.Journal of corporate Finance, 12,381-402

Governance, K. N. (2006). Pedoman Umum Good Corporate Governance Indonesia, Jakarta.

Muh. Arief Ujiyanto dan Bambang Agus Pramuka, 2007. Mekanisme Corporate Governance, Manajemen Laba dan Kinerja Keuangan . Simposium Nasional Akuntansi X

Nur Ariani, R. A. (2017).Pengaruh Struktur Kepemilikan Saham Terhadap Pengungkapan Corporate Social Responsibility (CSR) Pada Perusahaan Manufaktur (Sektor Industri Barang Konsumsi) yang Terdaftar di Bursa Efek Indonesia.

Sulastri. (2016). Pengaruh Good Corporate Governance Terhadap Kinerja Keuangan Perusahaan Yang Terdaftar Dalam Corporate Governance Perception Index (CGPI), Skripsi.Universitas Satya Negara Indonesia.

Sumartha, E. (2016). Pengaruh Struktur Kepemilikan Terhadap Kebijakan Dividen Pada Perusahaan Manufaktur, Volume 12, Nomor 2.

Wiwik Sriayu, G. P., \& Harta Mimba, N. S. (2013). Pengaruh Karakteristik Perusahaan Terhadap Corporate Social Responsibility Disclosure, 326344. 


\title{
PENGARUH KOMPENSASI KARYAWAN, MORALITAS \\ INDIVIDU, KEADILAN ORGANISASI DAN SISTEM PENGENDALIAN INTERN TERHADAP KECURANGAN (Studi \\ Empiris Pada PT. Bank Central Asia Tbk. Kantor Cabang Pembantu Ruko Roxy Mas Jakarta)
}

\author{
Jahormin Simarmata, SE., Ak., M.Ak \\ Intan Kartika Sari \\ jahormin.simarmata@gmail.com, intankartika20@gmail.com \\ Fakultas Ekonomi \& Bisnis - Program Studi Akuntansi \\ Universitas Satya Negara Indonesia
}

\begin{abstract}
ABSTRAK
Penelitian ini bertujuan untuk mengetahui pengaruh kompensasi karyawan, moralitas individu, keadilan organisasi dan sistem pengendalian intern terhadap kecurangan. Populasi dalam penelitian ini adalah seluruh karyawan PT. Bank Central Asia Tbk. Kantor Cabang Pembantu Ruko Roxy Mas Jakarta. Dalam penelitian ini menggunakan metode purposive sampling dengan responden sebanyak 49 responden. Data yang digunakan dalam penelitian ini dikategorikan sebagai data primer. Data dikumpulkan melalui kuesioner. Data diolah dan dianalisis menggunakan program aplikasi IBM Statistic Program Social Science (SPSS) versi 22.0. Hasil pengujian menunjukkan bahwa secara parsial kompensasi karyawan, moralitas individu, keadilan organisasi dan sistem pengendalian intern berpengaruh signifikan terhadap kecurangan, serta terdapat pengaruh simultan kompensasi karyawan, moralitas individu, keadilan organisasi dan sistem pengendalian intern terhadap kecurangan.

Kata kunci : Kompensasi Karyawan, Moralitas Individu, Keadilan Organisasi, Sistem Pengendalian Intern, Kecurangan.
\end{abstract}

\section{ABSTRACT}

This research aims to determine the effect of employee compensation, individual morality, organizational justice and internal control systems on fraud. The population in this research were all employees at PT. Bank Central Asia Tbk. Ruko Roxy Mas Sub-Branch Office in Jakarta. In this research using a purposive sampling method with 49 respondents. The data used in this research are categorized as primary data. Data collected through a questionnaire. Data were processed and analyzed using the IBM Statistics Social Program (SPSS) application program version 22.0. The results of research show that partially employee compensation, individual morality, organizational justice and internal control systems have a significant effect on fraud, and simultaneously that the employee compensation, individual morality, organizational justice and internal control systems have a significant effect on fraud.

Keywords : Employee Compensation, Individual Morality, Organizational Justice, Internal Control System, Fraud.

Jurnal Ilmiah Akuntansi dan Ekonomi Volume. 5 Nomor. 2, Agustus 2020 Hal. 55 


\section{PENDAHULUAN}

\section{Latar Belakang}

Seiring dengan perkembangan zaman yang semakin maju membuat Masyarakat lebih memilih untuk menyimpan uang di bank karena banyak manfaat yang didapat dengan menyimpan uang di bank, salah satunya yaitu rasa aman dan memudahkan masyarakat dalam melakukan transaksi bisnis yang dijalankan. Salah satu aspek berkembangnya dunia perbankan adalah beragamnya produk-produk perbankan yang menarik dengan teknologi yang modern sehingga Masyarakat bisa memilih untuk transaksi keuangan dan investasi dengan cepat dan tepat sesuai dengan kebutuhan mereka.

Walaupun sudah dibentuk sistem pengawasan dalam perbankan, operasional dalam suatu perbankan dapat menyebabkan manajemen puncak memiliki keterbatasan dalam berkomunikasi dengan unit yang terkait untuk mengetahui kinerja para karyawannya. Hal ini menyebabkan sebuah kesulitan dalam mengetahui apakah prosedur-prosedur yang ditetapkan oleh suatu perbankan sudah ditaati oleh para karyawannya. Ini menjadi keterbatasan antara manajemen puncak dengan operasional untuk mengetahui kelemahan dalam suatu pengawasan yang telah dibuat sehingga dapat menyebabkan terjadinya penyimpangan dan kecurangan, seperti pencurian, penggelapan, pemalsuan, dan lain-lain.

Menurut Association of Certified Fraud Examiners (ACFE) dalam Report to the Nation on Occupational Fraud and Abuse (ACFE, 2016) ditemukan sebesar $12 \%$ kasus financial statement fraud yang terjadi pada perusahaan yang bergerak di bidang perbankan dan pelayanan keuangan, dimana jumlah persentase ini lebih tinggi dibandingkan dengan rata-rata kasus financial statement fraud yang terjadi dalam berbagai bidang industri sejumlah 9.6\%. Hal ini memberikan gambaran bahwa industri perbankan dan layanan keuangan memiliki risiko yang besar sebagai tempat terjadinya kasus kecurangan pada laporan keuangan. (Centhya Wati, 2017:157).

Beberapa faktor yang dapat mempengaruhi seseorang melakukan kecurangan seperti kompensasi karyawan, moralitas individu, keadilan organisasi dan sistem pengendalian intern dan lainnya.

\section{Perumusan Masalah}

Berdasarkan latar belakang masalah yang telah diuraikan sebelumnya, maka perumusan masalah yang dapat diidentifikasi dalam penelitian ini antara lain :

1. Apakah kompensasi karyawan berpengaruh terhadap kecurangan ?

2. Apakah moralitas individu berpengaruh terhadap kecurangan ?

3. Apakah keadilan organisasi berpengaruh terhadap kecurangan ?

4. Apakah sistem pengendalian intern berpengaruh terhadap kecurangan ?

5. Apakah kompensasi karyawan, moralitas individu, keadilan organisasi dan sistem pengendalian intern berpengaruh simultan terhadap kecurangan ?

\section{Tujuan dan Kegunaan Penelitian}

Tujuan dalam penelitian ini adalah untuk mengetahui pengaruh kompensasi karyawan, moralitas individu, keadilan organisasi, dan sistem pengendalian intern terhadap kecurangan baik dengan masing-masing (parsial) maupun dengan cara 
bersama-sama (simultan), serta untuk mengetahui apakah penelitian ini memiliki konsistensi yang sama dengan penelitian sebelumnya.

Kegunaan penelitian ini diharapkan dapat memberikan sarana untuk menambah wawasan dan pengetahuan mengenai ilmu yang sedang diteliti khususnya mengenai pengaruh kompensasi karyawan, moralitas individu, keadilan organisasi dan sistem pengendalian intern terhadap kecurangan. Bagi Pembaca, dapat memperoleh dan menambah ilmu pengetahuan. Bagi Calon Peneliti, penelitian ini diharapkan dapat digunakan sebagai referensi tambahan bagi peneliti selanjutnya yang akan mengadakan kajian yang lebih luas terkait dengan penelitian ini.

Hasil penelitian ini diharapkan dapat memberikan informasi mengenai pengaruh kompensasi karyawan, moralitas individu, keadilan organisasi dan sistem pengendalian intern terhadap kecurangan. Kecurangan dapat terjadi didalam dunia perbankan sehingga peneliti berharap dapat memberikan masukan untuk perbaikan dan perubahan yang positif bagi perusahaan.

\section{LANDASAN TEORI}

\section{Kompensasi Karyawan}

Menurut Garry Desler (1996) kompensasi adalah "Semua bentuk penggajian atau ganjaran mengalir kepada pegawai dan timbul dari kepegawaiannya mereka" (Waseso, 2017:103). Sedangkan menurut T Hani Handoko (1995) kompensasi adalah "Segala sesuatu yang diterima para karyawan sebagai balas jasa untuk kerja mereka" (Waseso, 2017:103).

Menurut Ivancevich (1995) dalam (Kadarisman, 2016:6) kompensasi adalah fungsi Human Resouce Management (HRM) yang berhubungan dengan setiap jenis reward yang diterima individu sebagai balasan atas pelaksanaan tugas-tugas organisasi. Pegawai menukarkan tenaganya untuk mendapatkan reward finansial maupun nonfinansial.

\section{Moralitas Individu}

Moral menurut Kamus Besar Bahasa Indonesia adalah "tentang baik atau buruk yang diterima umum mengenai akhlak dan budi pekerti, kondisi mental yang memengaruhi seseorang menjadi tetap bersemangat, berani, disiplin dan sebagainya" (Agus Santoso, 2012:82).

Moralitas (dari kata sifat latin moralis) mempunyai arti yang pada dasarnya sama dengan "moral", artinya segi moral suatu perbuatan baik atau buruk. Moralitas adalah sifat moral atau keseluruhan asas dan nilai yang berkenaan dengan baik dan buruk. (Bertens, 1993) dalam (Ranti, 2016).

\section{Keadilan Organisasi}

Keadilan berasal dari kata adil, menurut Kamus Besar Bahasa Indonesia adil adalah "tidak sewenang-wenang, tidak memihak, tidak berat sebelah. Adil terutama mengandung arti bahwa suatu keputusan dan tindakan didasarkan atas normanorma yang objektif' (Agus Santoso, 2012:85).

Keadilan organisasi menurut (Khatri, et al. 1999) dalam Mariani (2011) dalam Lisa Amelia Herman (2013) adalah istilah untuk mendeskripsikan kesamarataan atau keadilan ditempat kerja yang berfokus bagaimana para pekerja 
menyimpulkan apakah mereka diperlakukan secara adil dalam pekerjaannya dan bagaimana kesimpulan tersebut kemudian mempengaruhi variabel-variabel lain yang berhubungan dengan pekerjaan.

\section{Sistem Pengendalian Intern}

Sistem pengendalian intern menurut (Hery, 2017:132) adalah kebijakan dan prosedur yang dirancang untuk memberikan kepastian yang layak bagi manajemen bahwa perusahaan telah mencapai tujuan dan sasarannya. Manajemen memiliki tiga tujuan umum dalam merancang sistem pengendalian internal yang efektif yaitu, keandalan pelaporan keuangan, efisiensi dan efektivitas operasi dan ketaatan pada hukum dan peraturan. Untuk mencapai tujuan tersebut, maka terdapat elemen Sistem Pengendalian Intern, yaitu : Lingkungan Pengendalian, Penilaian Risiko, Aktivitas Pengendalian Internal, Informasi dan Komunikasi Akuntansi, dan Pemantauan

\section{Kecurangan}

Definisi Fraud Menurut Black Law Dictionary (8th Ed) dalam (Diaz Priantara, 2013:3-4) adalah suatu perbuatan sengaja untuk menipu atau membohongi, suatu tipu daya atau cara-cara yang tidak jujur atau mengambil atau menghilangkan uang, harta, hak yang sah milik orang lain baik karena suatu tindakan atau dampak yang fatal dari tindakan itu sendiri. Sedangkan yang lebih umum, menurut the Association of Certified Fraud Examiner (ACFE) dalam (Diaz Priantara, 2013:5) adalah mendefinisikan Fraud sebagai Segala upaya untuk mengelabui atau memperdaya pihak lain untuk mendapatkan manfaat. Fraud meliputi banyak ragam tindakan penyelewengan atau perbuatan yang tidak sesuai hukum untuk memperoleh manfaat ekonomis tidak selalu materi secara langsung.

\section{METODOLOGI PENELITIAN}

\section{Tempat dan Waktu Penelitian}

Penelitian ini dilaksanakan pada PT. Bank Central Asia Tbk. Kantor Cabang Pembantu Ruko Roxy Mas Jakarta yang berlokasi di Ruko Roxy Mas Blok C5 No. 6-8 Jl. KH. Hasyim Ashari No 125, Jakarta Pusat 10150, pada bulan Mei sampai Juli 2020.

\section{Desain Penelitian}

Desain penelitian yang digunakan adalah penelitian kausal (Causal Research), yaitu penelitian yang bersifat sebab dan akibat. Digunakan untuk mengetahui pengaruh antara satu atau lebih variabel bebas (Independent Variabel):

Kompensasi Karyawan, Moralitas Individu, Keadilan Organisasi, dan Sistem Pengendalian Intern terhadap variabel terikat (Dependent Variabel) Kecurangan. Untuk mempermudah pemahaman, maka dibuat gambar kerangka penelitian berikut . 
Variabel Independen

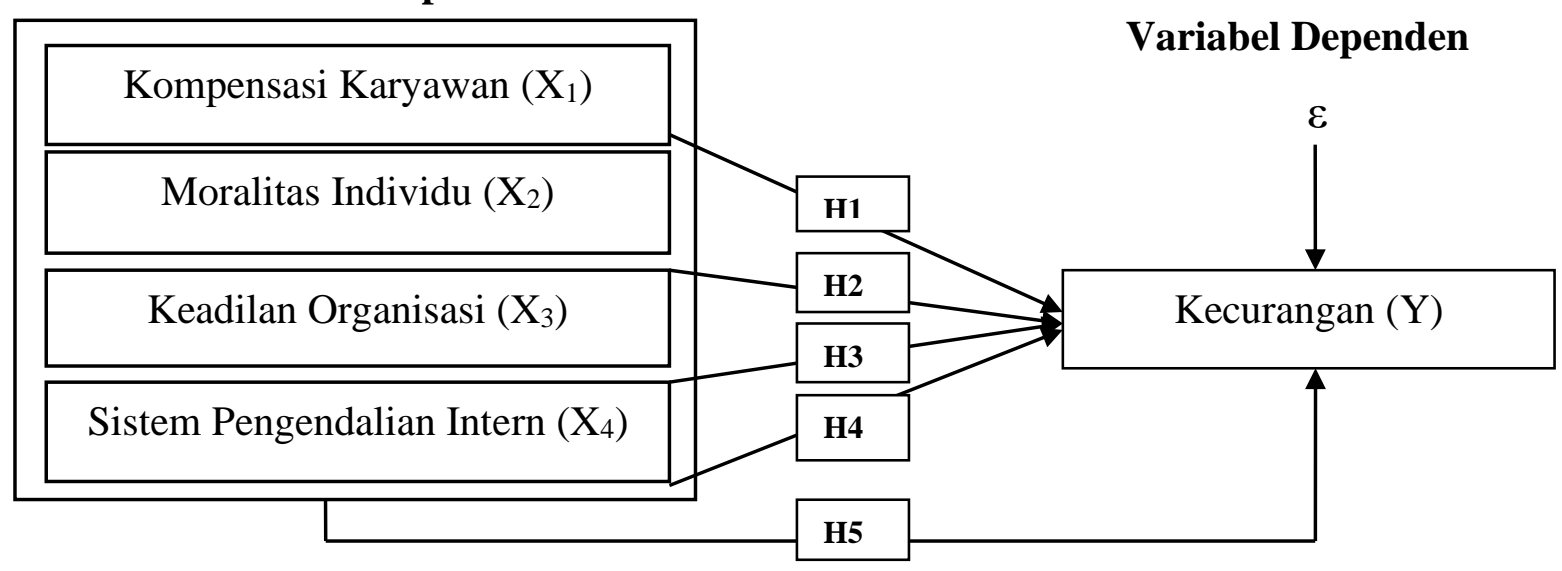

\section{Jenis Data}

Gambar : Kerangka Penelitian

Jenis data yang digunakan dalam penelitian ini adalah data primer, yaitu sumber data yang diperoleh langsung dari objek yang diteliti untuk mengukur variabel independen (Kompensasi Karyawan, Moralitas Individu, Keadilan Organisasi dan Sistem Pengendalian Intern), dan variabel dependen (Kecurangan) yang diambil dari hasil pengujian kuesioner.

\section{Populasi dan Sampel Penelitian}

Populasi dalam penelitian ini adalah karyawan yang bekerja di PT. Bank Central Asia Tbk. Kantor Cabang Pembantu Ruko Roxy Mas Jakarta.

Sampel dalam penelitian ini diambil dengan menggunakan metode purposive sampling. Kreteria responden yang dijadikan sampel dalam penelitian ini adalah sebagai berikut :

1. Bagian operasional, bagian audit internal, bagian finance, dan bagian HRD.

2. Telah berkerja minimal 1 tahun.

\section{Variabel Penelitian}

Variabel bebas atau variabel independen yang digunakan penelitian ini adalah kompensasi karyawan $\left(\mathrm{X}_{1}\right)$, moralitas individu $\left(\mathrm{X}_{2}\right)$, keadilan organisasi $\left(\mathrm{X}_{3}\right)$ dan sistem pengendalian intern $\left(\mathrm{X}_{4}\right)$. Sedangkan variabel terikat atau variabel dependen yang digunakan penelitian ini adalah Kecurangan (Y).

\section{Skala Pengukuran}

Skala yang digunakan adalah skala likert lima point dengan rentang 1 - 5 yang memberikan gambaran sampai seberapa jauh responden melaksanakan fungsi sesuai dengan penyataan yang diberikan (Sugiyono, 2016:93).

\section{Hipotesis Penelitian}

Pengujian hipotesis bertujuan untuk mengetahui pengaruh kompensasi karyawan, moralitas individu, keadilan organisasi dan sistem pengendalian intern terhadap kecurangan. Adapun hipotesis yang akan diuji adalah sebagai berikut :

1) Ho1 : Kompensasi karyawan tidak berpengaruh terhadap kecurangan.

2) Ha1 : Kompensasi karyawan berpengaruh terhadap kecurangan. 
3) Ho2 : Moralitas individu tidak berpengaruh terhadap kecurangan.

4) Ha2 : Moralitas individu berpengaruh terhadap kecurangan.

5) Ho3 : Keadilan organisasi tidak berpengaruh terhadap kecurangan.

6) $\mathrm{Ha} 3$ : Keadilan organisasi bepengaruh terhadap kecurangan.

7) Ho4 : Sistem pengendalian intern tidak berpengaruh terhadap kecurangan.

8) Ha4 : Sistem pengendalian intern berpengaruh terhadap kecurangan.

9) Ho5 : Kompensasi karyawan, moralitas individu, keadilan organisasi dan sistem pengendalian intern tidak berpengaruh simultan terhadap kecurangan.

10) Ha5 : Kompensasi karyawan, moralitas individu, keadilan organisasi dan sistem

pengendalian intern berpengaruh simultan terhadap kecurangan.

\section{Metode Analisis Data dan Hipotesis}

Metode statistika yang digunakan dalam menguji data dan hipotesis dalam penelitian ini dilakukan dengan menggunakan program aplikasi IBM Statistic Program Social Science (SPSS) versi 22.0. Sebelum analisis data, terlebih dahulu dilakukan uji validitas dan reliabilitas data, kemudian uji asumsi klasik ( normalitas, multikolonieritas, heteroskedastisitas, dan autokorelasi). Uji hipotesis dilakukan dengan uji t, uji F dan koefisien determinasi.

\section{ANALISIS HASIL DAN PEMBAHASAN}

Kuesioner yang disebar berjumlah 50 kuesioner dan jumlah kuesioner yang kembali dan dapat diolah adalah sebanyak 49 kuesioner. Dengan menggunakan 49 kuesioner yang kembali, peneliti menyimpulkan bahwa kuesioner tesebut telah layak untuk diolah dan untuk selanjutnya dilakukan penelitian. Tabel berikut, menunjukkan analisis statistic deskriptif yang menggambarkan nilai maksimum, minimum, rata-rata dan standar deviasi variable penelitian.

\section{Analisis Statistik Deskriptif}

Hasil Uji Statistik Deskriptif

Descriptive Statistics

\begin{tabular}{|l|r|r|r|r|r|r|}
\hline & $\mathrm{N}$ & Minimum & Maximum & \multicolumn{2}{|c|}{ Mean } & Std. Deviation \\
\cline { 2 - 6 } & Statistic & Statistic & Statistic & Statistic & Std. & Error \\
\hline Total_Kompensasi_Karyawan & 49 & 33 & 50 & 41,71 &, 595 & 4,163 \\
Total_Moralitas_Individu & 49 & 29 & 40 & 34,53 &, 360 & 2,517 \\
Total_Keadilan_Organisasi & 49 & 32 & 50 & 39,20 &, 643 & 4,500 \\
Total_Sistem_Pengendalian_Intern & 49 & 32 & 44 & 36,53 &, 412 & 2,887 \\
Total_Kecurangan & 49 & 33 & 50 & 41,65 &, 545 & 3,816 \\
Valid N (listwise) & 49 & & & & & \\
\hline
\end{tabular}

Sumber Data : Hasil Output SPSS 22.0

\section{Uji Validitas}

Pengujian validitas data dimaksudkan untuk mengetahui apakah data yang terkumpul dari responden telah memenuhi kreteria sebagai alat ukur yang tepat.

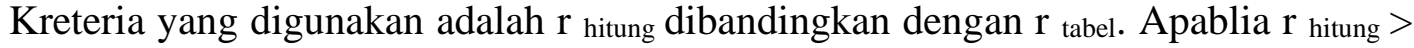
$\mathrm{r}$ tabel disimpulkan bahwa instrumen tersebut dianggap valid. Uji validitas ini dilakukan dengan membandingkan nilai $r_{\text {hitung }}$ dengan $r_{\text {tabel }}$. Dengan penelitian ini 
$\mathrm{df}=\mathrm{n}-2$ dimana $\mathrm{n}=49 \mathrm{df}=49-2=47$ dengan $\alpha 0,05 \mathrm{r}$ tabel sebesar 0,2816. Hasil uji validitas untuk variable penelitian, disajikan pada table berikut.

\section{Tabel}

\section{Hasil Uji Validitas Variabel Penelitian}

Item - Total Statistics

\begin{tabular}{|l|c|c|c|c|}
\hline \multicolumn{1}{|c|}{ Variabel Penelitian } & $\begin{array}{c}\text { Corrected Item-Total } \\
\text { Correlation }\end{array}$ & r-tabel & N of Items & Keterangan \\
\hline Kompensasi Karyawan $\left(\mathrm{X}_{1}\right)$ & $.322 \mathrm{~s} / \mathrm{d} 771$ &, 2816 & 10 & Valid \\
\hline Moralitas Individu $\left(\mathrm{X}_{2}\right)$ & $.309 \mathrm{~s} / \mathrm{d} .515$ &, 2816 & 9 & Valid \\
\hline Keadilan Organisasi $\left(\mathrm{X}_{3}\right)$ & $.314 \mathrm{~s} / \mathrm{d} .710$ &, 2816 & 10 & Valid \\
\hline Sistem Pengendalian Intern $\left(\mathrm{X}_{4}\right)$ & $.359 \mathrm{~s} / \mathrm{d} 612$ &, 2816 & 9 & Valid \\
\hline Kecurangan $(\mathrm{Y})$ & $.417 \mathrm{~s} / \mathrm{d} 732$ &, 2816 & 10 & Valid \\
\hline
\end{tabular}

Sumber Data : Hasil Output SPSS 22.0

Berdasarkan hasil pengujian validitas variabel penelitian menjelaskan bahwa nilai Corrected Item-Total Correlation ( $\mathrm{r}$ hitung) yang dihasilkan untuk masingmasing variable dan butir pernyataan, nilainya lebih besar dari $r_{\text {tabel }}$ yaitu 0,2816 , sehingga dapat disimpulkan bahwa semua variable penelitian dinyatakan valid.

\section{Uji Reliabilitas}

Uji reliabilitas digunakan untuk menunjukkan akurasi, ketepatan dan konsistensi kuesioner dalam mengukur variabel. Suatu variabel dikatakan reliable apabila memberikan nilai Cronbach's Alpha $>0,70$. Aturan dalam uji ini adalah sebagai berikut :

a. Jika nilai Cronbach's Alpha $>0,70$ maka dapat dikatakan reliable.

b. Jika nilai Cronbach's Alpha $<0,70$ maka dapat dikatakan reliable.

\section{Tabel}

Hasil Uji Reliabilitas

Reliability Statistics

\begin{tabular}{|c|c|c|c|c|}
\hline Variabel Penelitian & Cronbach's Alpha & $\begin{array}{c}\text { Batas } \\
\text { Signifikansi }\end{array}$ & N of Items & Keterangan \\
\hline Kompensasi Karyawan $\left(\mathrm{X}_{1}\right)$ &, 825 &, 70 & 10 & Reliabel \\
\hline Moralitas Individu $\left(\mathrm{X}_{2}\right)$ &, 721 &, 70 & 9 & Reliabel \\
\hline Keadilan Organisasi $\left(\mathrm{X}_{3}\right)$ &, 856 &, 70 & 10 & Reliabel \\
\hline Sistem Pengendalian Intern $\left(\mathrm{X}_{4}\right)$ &, 777 &, 70 & 9 & Reliabel \\
\hline Kecurangan $(\mathrm{Y})$ &, 839 &, 70 & 10 & Reliabel \\
\hline
\end{tabular}

Sumber Data : Hasil Output SPSS 22.0

Berdasarkan hasil pengujian reliabilitas variabel Kompensasi Karyawan $\left(\mathrm{X}_{1}\right)$, Moralitas Individu $\left(\mathrm{X}_{2}\right)$, Keadilan Organisasi $\left(\mathrm{X}_{3}\right)$, Sistem Pengendalian Intern $\left(\mathrm{X}_{4}\right)$ dan Kecurangan (Y) menunjukkan Cronbach's Alpha > 0,70. Hal ini dapat disimpulkan bahwa pernyataan-pernyataan dalam masing-masing variabel adalah reliable, yang berarti bahwa hasil pengukuran variabel adalah konsisten.

\section{Uji Asumsi Klasik}

\section{a. Uji Normalitas}


Uji normalitas bertujuan untuk menguji apakah dalam model regresi, variabel pengganggu atau residual memiliki distribusi normal. Uji normalitas data dapat dilakukan dengan menggunakan One Sample Kolmogorov Smirnov Test pada kolom Asymp Sig (2-tailed) yaitu jika p value (sig) > 0,05 berarti model berdistribusi normal, seperti pada table berikut .

Tabel

Hasil Uji Normalitas

One-Sample Kolmogorov-Smirnov Test

\begin{tabular}{|c|c|c|}
\hline & & $\begin{array}{l}\text { Unstandardized } \\
\text { Residual }\end{array}$ \\
\hline \multicolumn{2}{|l|}{$\mathrm{N}$} & 49 \\
\hline \multirow[t]{2}{*}{ Normal Parameters ${ }^{a, b}$} & Mean &, 0000000 \\
\hline & Std. Deviation & 2,17507449 \\
\hline \multirow[t]{2}{*}{ Most Extreme Differences } & Absolute & , 104 \\
\hline & $\begin{array}{l}\text { Positive } \\
\text { Negative }\end{array}$ & $\begin{array}{r}, 104 \\
-, 060\end{array}$ \\
\hline \multicolumn{2}{|l|}{ Test Statistic } &, 104 \\
\hline \multicolumn{2}{|l|}{ Asymp. Sig. (2-tailed) } &, $200^{c, d}$ \\
\hline \multicolumn{3}{|l|}{ a. Test distribution is Normal. } \\
\hline \multicolumn{3}{|l|}{ b. Calculated from data. } \\
\hline \multicolumn{3}{|c|}{ c. Lilliefors Significance Correction. } \\
\hline $\mathrm{d}$. This is a lower bound of $\mathrm{t}$ & cance. & \\
\hline
\end{tabular}

Sumber Data : Hasil Output SPSS 22.0

Uji Normalitas juga dapat dilakukan dengan metode normal probality plot, jika data menyebar disekitar garis diagonal dan mengikuti arah garis diagonal, maka model regresi memenuhi asumsi normalitas, seperti pada gambar berikut.

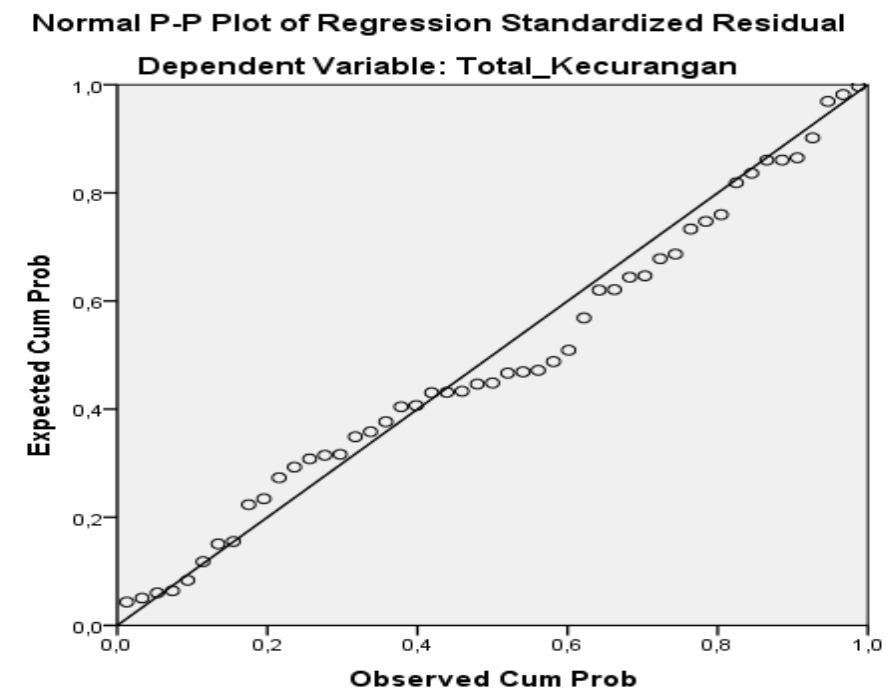

Gambar

Hasil Uji Normalitas Grafik P-Plot

Sumber Data : Hasil Output SPSS 22.0

\section{Uji Multikolonieritas}

Uji multikolonieritas digunakan untuk menguji apakah model regresi ditemukan adanya korelasi antar variabel bebas atau variabel independen. Untuk 
menguji adanya multikolonieritas dapat dilihat dari nilai tolerance dan Varian Inflation Factor (VIF). Berdasarkan nilai tolerance, nilai yang terbentuk harus di atas 0,10 dan bila menggunakan VIF, nilai yang terbentuk harus kurang dari 10 . Untuk mengetahui ada atau tidaknya multikolonieritas dalam model regresi dapat dilihat pada hasil pengujian sebagai berikut :

\section{Tabel}

\section{Hasil Uji Multikolonieritas}

Coefficients $^{\mathrm{a}}$

\begin{tabular}{|c|c|c|c|c|c|c|c|c|}
\hline \multirow{2}{*}{\multicolumn{2}{|c|}{ Model }} & \multicolumn{2}{|c|}{$\begin{array}{c}\text { Unstandardized } \\
\text { Coefficients }\end{array}$} & \multirow{2}{*}{$\begin{array}{c}\begin{array}{c}\text { Stand } \\
\text { ardize } \\
d \\
\text { Coeffic } \\
\text { ients }\end{array} \\
\text { Beta }\end{array}$} & \multirow[b]{2}{*}{$t$} & \multirow[b]{2}{*}{ Sig. } & \multicolumn{2}{|c|}{ Collinearity Statistics } \\
\hline & & B & $\begin{array}{l}\text { Std. } \\
\text { Error }\end{array}$ & & & & Tolerance & VIF \\
\hline \multirow[t]{5}{*}{1} & (Constant) & $-9,401$ & 5,819 & & $-1,616$ &, 113 & & \\
\hline & Total_Kompensasi_Karyawan & ,391 & ,086 & 427 & 4,548 & 000 & ,839 & 1,192 \\
\hline & Total_Moralitas_Individu & ,302 & ,138 &, 199 & 2,192 & ,034 & ,893 & 1,120 \\
\hline & Total_Keadilan_Organisasi & 169 &, 080 & 199 & 2,104 & ,041 & ,826 & 1,210 \\
\hline & Total_Sistem_Pengendalian_Intern & ,484 & ,130 & ,366 & 3,713 & ,001 & 758 & 1,320 \\
\hline
\end{tabular}

a. Dependent Variable: Total_Kecurangan

Sumber Data : Hasil Output SPSS 22.0

Berdasarkan hasil pengujian dapat diketahui bahwa nilai Tolerance keempat variabel Kompensasi Karyawan, Moralitas Individu, Keadilan Organisasi dan Sistem Pengendalian Intern adalah $\geq 0,10$ dan nilai Variance Inflation Factor (VIF) $\leq$ dari 10, sehingga dapat disimpulkan bahwa antar variabel independen tidak terjadi multikolonieritas.

\section{Uji Heteroskedastisitas}

Uji heteroskedastisitas bertujuan untuk menguji apakah dalam model regresi terjadi ketidaksamaan antara varian dari residual satu pengamatan ke pengamatan lain tetap. Ada tidaknya heteroskedastisitas dalam persamaan regresi dapat dideteksi dengan menggunakan uji glejser. Jika probablitas signifikannya di atas tingkat kepercayaan yaitu 5\% atau 0,05 maka dapat disimpulkan tidak terjadi heteroskedastisitas.

\section{Tabel}

\section{Hasil Uji Heterokedastisitas}

Coefficients $^{\mathrm{a}}$

\begin{tabular}{|c|c|c|c|c|c|c|}
\hline \multirow[b]{2}{*}{ Mod } & & \multicolumn{2}{|c|}{$\begin{array}{l}\text { Unstandardized } \\
\text { Coefficients }\end{array}$} & \multirow{2}{*}{$\begin{array}{c}\begin{array}{c}\text { Standardized } \\
\text { Coefficients }\end{array} \\
\text { Beta }\end{array}$} & \multirow[b]{2}{*}{$\mathrm{T}$} & \multirow[b]{2}{*}{ Sig. } \\
\hline & & $\mathrm{B}$ & Std. Error & & & \\
\hline \multirow[t]{5}{*}{1} & (Constant) & $-2,707$ & 3,454 & &,- 784 & ,437 \\
\hline & Total_Kompensasi_Karyawan &, 011 &, 051 & 034 & ,221 & ,826 \\
\hline & Total_Moralitas_Individu & ,206 &, 082 & ,370 & 2,521 & , 415 \\
\hline & Total_Keadilan_Organisasi &, 014 & ,048 &, 045 & ,295 & ,769 \\
\hline & Total_Sistem_Pengendalian_Intern &,- 104 &, 077 &,- 214 & $-1,342$ & , 187 \\
\hline
\end{tabular}

a. Dependent Variable: Abs_Res

Sumber Data : Hasil Output SPSS 22.0 
Hasil Uji Heteroskedastisitas - Scatterplot dapat juga dilihat pada gambar sebagai berikut, dimana titik-titik menyebar di atas dan di bawah sumbu 0, dan tidak membentuk pola tertentu, dapat disimpulkan tidak terjadi heteroskedastisitas. :

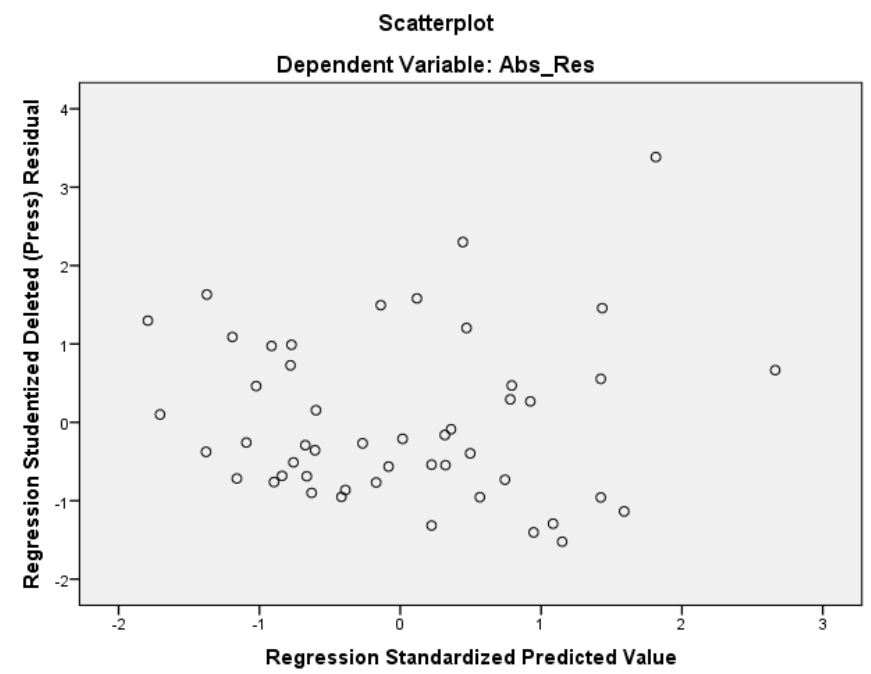

Gambar

Hasil Uji Heteroskedastisitas - Scatterplot Sumber Data : Output SPSS 22.0

\section{Uji Autokorelasi}

Uji autokorelasi bertujuan untuk menguji apakah dalam model regresi linear ada korelasi antara kesalahan pengganggu pada periode $\mathrm{t}$ dengan kesalahan pengganggu pada periode t-1 (sebelumnya). Untuk mendeteksi ada tidaknya autokorelasi digunakan uji Durbin-Watson. Berdasarkan tabel statistic DurbinWatson, dengan signifikansi 0,05 dan jumlah data $(\mathrm{n})=49$, serta $\mathrm{k}=4$ (k adalah jumlah variabel independen) sehingga didapatkan nilai dL sebesar 1,3701 dan nilai dU sebesar 1,7210 dan untuk mengetahui apakah terdapat autokorelasi pada model regresi, maka dapat dilihat pada hasil pengujian sebagai berikut :

\section{Tabel}

\section{Hasil Uji Autokorelasi}

\begin{tabular}{|c|c|c|c|c|c|}
\hline \multicolumn{6}{|c|}{ Model Summary } \\
\hline Model & $\mathrm{R}$ & R Square & $\begin{array}{l}\text { Adjusted R } \\
\text { Square }\end{array}$ & $\begin{array}{l}\text { Std. Error of the } \\
\text { Estimate }\end{array}$ & Durbin-Watson \\
\hline 1 &, $822^{a}$ & ,675 & ,646 & 2,272 & 2,153 \\
\hline \multicolumn{6}{|c|}{$\begin{array}{l}\text { a. Predictors: (Constant), Total_Sistem_Pengendalian_Intern, Total_Moralitas_Individu, } \\
\text { Total_Kompensasi_Karyawan, Total_Keadilan_Organisasi } \\
\text { b. Dependent Variable: Total_Kecurangan }\end{array}$} \\
\hline umbe & : Outp & it SPSS 22 & & & \\
\hline
\end{tabular}

Dari hasil Uji Autokorelasi didapatkan nilai Durbin-Watson yang dihasilkan dari model regresi adalah 2,153 terletak diantara dU atau 1,7210 dan 4 - dU atau 2,2790. Dapat disimpulkan $\mathrm{dU}<\mathrm{d}<4-\mathrm{dU}=1,7210<2,153<2,2790$ maka hipotesis nol diterima yang berarti tidak ada autokorelasi, positif atau negatif. 


\section{Teknik Analisis Data}

\section{Analisis Korelasi}

Analisis korelasi bertujuan untuk mengukur kekuatan asosiasi (hubungan linier antara dua variabel. Hasil pengujian analisis korelasi adalah sebagai berikut :

\section{Tabel}

\section{Hasil Analisis Korelasi}

Correlations

\begin{tabular}{|c|c|c|c|c|c|c|}
\hline & & $\begin{array}{c}\text { Total_Kompe } \\
\text { nsasi_Karya } \\
\text { wan }\end{array}$ & $\begin{array}{c}\text { Total_Moral } \\
\text { itas_Individ } \\
u\end{array}$ & $\begin{array}{c}\text { Total_Kea } \\
\text { dilan_Orga } \\
\text { nisasi }\end{array}$ & $\begin{array}{c}\text { Total_Sist } \\
\text { em_Peng } \\
\text { endalian_I } \\
\text { ntern }\end{array}$ & $\begin{array}{l}\text { Total_Ke } \\
\text { curangan }\end{array}$ \\
\hline \multirow[t]{3}{*}{$\begin{array}{l}\text { Total_Kompensasi_Karyaw } \\
\text { an }\end{array}$} & $\begin{array}{l}\text { Pearson } \\
\text { Correlation }\end{array}$ & 1 & & & & \\
\hline & Sig. (2-tailed) & & ,324 & ,272 & ,005 & 000 \\
\hline & $\mathrm{N}$ & 49 & 49 & 49 & 49 & 49 \\
\hline \multirow[t]{3}{*}{ Total_Moralitas_Individu } & $\begin{array}{l}\text { Pearson } \\
\text { Correlation }\end{array}$ & , 144 & 1 & ,303* & ,207 &, $397^{* *}$ \\
\hline & Sig. (2-tailed) & ,324 & & ,034 & , 154 & 005 \\
\hline & $\mathrm{N}$ & 49 & 49 & 49 & 49 & 49 \\
\hline \multirow[t]{3}{*}{ Total_Keadilan_Organisasi } & $\begin{array}{l}\text { Pearson } \\
\text { Correlation }\end{array}$ & , 160 &, $303^{*}$ & 1 &, $343^{*}$ & ,453** \\
\hline & Sig. (2-tailed) & ,272 &, 034 & &, 016 & 001 \\
\hline & $\mathrm{N}$ & 49 & 49 & 49 & 49 & 49 \\
\hline \multirow[t]{3}{*}{$\begin{array}{l}\text { Total_Sistem_Pengendalia } \\
\text { n_Intern }\end{array}$} & $\begin{array}{l}\text { Pearson } \\
\text { Correlation }\end{array}$ &, $396^{* *}$ & ,207 &, $343^{*}$ & 1 &, $645^{* *}$ \\
\hline & Sig. (2-tailed) & ,005 & ,154 & ,016 & &, 000 \\
\hline & $\mathrm{N}$ & 49 & 49 & 49 & 49 & 49 \\
\hline \multirow[t]{3}{*}{ Total_Kecurangan } & $\begin{array}{l}\text { Pearson } \\
\text { Correlation }\end{array}$ & ,632* & ,397* &, $453^{* *}$ &, $645^{* *}$ & 1 \\
\hline & Sig. (2-tailed) &, 000 &, 005 &, 001 &, 000 & \\
\hline & $\mathrm{N}$ & 49 & 49 & 49 & 49 & 49 \\
\hline
\end{tabular}

**. Correlation is significant at the 0.01 level (2-tailed).

*. Correlation is significant at the 0.05 level (2-tailed).

Sumber Data : Hasil Output SPSS 22.0

Berdasarkan tabel 4.17, dapat disimpulkan bahwa hubungan masing-masing variabel penelitian yaitu sebagai berikut :

- Hubungan Kompensasi Karyawan $\left(\mathrm{X}_{1}\right)$ terhadap Kecurangan $(\mathrm{Y})$ diperoleh hasil sebesar 0,632 dengan signifikansi sebesar 0,000 $<0,05$. Angka ini menunjukkan bahwa Kompensasi Karyawan memiliki korelasi yang cukup kuat sebesar 63,2\% terhadap Kecurangan.

- Hubungan Moralitas Individu $\left(\mathrm{X}_{2}\right)$ terhadap Kecurangan $(\mathrm{Y})$ diperoleh hasil sebesar 0,397 dengan signifikansi sebesar 0,005 $<0,05$. Angka ini menunjukkan bahwa Moralitas Individu memiliki korelasi yang lemah sebesar 39,7\% terhadap Kecurangan.

- Hubungan Keadilan Organisasi $\left(\mathrm{X}_{3}\right)$ terhadap Kecurangan (Y) diperoleh hasil sebesar 0,453 dengan signifikansi sebesar 0,001 < 0,05. Angka ini menunjukkan bahwa Keadilan Organisasi memiliki korelasi yang cukup kuat sebesar 45,3\% terhadap Kecurangan.

- Hubungan Sistem Pengendalian Intern ( $\left.\mathrm{X}_{4}\right)$ terhadap Kecurangan (Y) diperoleh hasil sebesar 0,645 dengan signifikansi sebesar 0,000 $<0,05$. Angka ini menunjukkan bahwa Sistem Pengendalian Intern memiliki korelasi yang cukup kuat sebesar 64,5\% terhadap Kecurangan. 


\section{Analisis Regresi Linier Berganda}

Uji regresi berganda adalah hubungan secara linear antara dua atau lebih variabel independen dengan variabel dependen. Bertujuan untuk memprediksi besar variabel dependen dengan menggunakan data variabel independen yang sudah diketahui besarnya, Hasil pengujian regresi linier berganda dapat dilihat pada tabel sebagai berikut :

\section{Tabel}

Hasil Uji Regresi Linier Berganda

Coefficients $^{\mathrm{a}}$

\begin{tabular}{|c|c|c|c|c|c|c|}
\hline \multirow{2}{*}{\multicolumn{2}{|c|}{ Model }} & \multicolumn{2}{|c|}{$\begin{array}{c}\text { Unstandardized } \\
\text { Coefficients }\end{array}$} & \multirow{2}{*}{$\begin{array}{c}\text { Standardized } \\
\text { Coefficients }\end{array}$} & \multirow[b]{2}{*}{$\mathrm{t}$} & \multirow[b]{2}{*}{ Sig. } \\
\hline & & $\mathrm{B}$ & Std. Error & & & \\
\hline \multirow[t]{5}{*}{1} & (Constant) & $-9,401$ & 5,819 & & $-1,616$ &, 113 \\
\hline & Total_Kompensasi_Karyawan & ,391 & ,086 &, 427 & 4,548 &, 000 \\
\hline & Total_Moralitas_Individu & ,302 &, 138 & ,199 & 2,192 & ,034 \\
\hline & Total_Keadilan_Organisasi & , 169 &, 080 &, 199 & 2,104 &, 041 \\
\hline & Total_Sistem_Pengendalian_Intern & ,484 &, 130 & ,366 & 3,713 & 001 \\
\hline
\end{tabular}

a. Dependent Variable: Total_Kecurangan

Sumber Data : Hasil Output SPSS 22.0 berikut :

Berdasarkan tabel di atas maka dapat dianalisis model estimasi sebagai

$$
\begin{gathered}
\mathrm{Y}=\alpha+\beta 1 \mathrm{X}_{1}+\beta 2 \mathrm{X}_{2}+\beta 3 \mathrm{X}_{3}+\beta 4 \mathrm{X}_{4}+\varepsilon \text { atau } \\
\mathrm{Y}=-9,401+0,391 \mathrm{X}_{1}+0,302 \mathrm{X}_{2}+0,169 \mathrm{X}_{3}+0,484 \mathrm{X}_{4}+\varepsilon
\end{gathered}
$$

Keterangan :

$\mathrm{Y}:$ Kecurangan.

$\alpha$ : Konstanta.

$\beta$ : Koefisien regresi (menunjukkan angka peningkatan atau penurunan variabel dependen yang didasarkan pada hubungan nilai variabel independen)

$\mathrm{X}_{1}$ : Kompensasi Karyawan.

$\mathrm{X}_{2}$ : Moralitas Individu.

$\mathrm{X}_{3}$ : Keadilan Organisasi.

$\mathrm{X}_{4}$ : Sistem Pengendalian Intern.

$\varepsilon$ : Standar Error.

Dari persamaan di atas dapat dijelaskan bahwa :

1. Nilai konstanta $(\alpha)-9,401$ menunjukkan besarnya variabel independen (kompensasi karyawan, moralitas individu, keadilan organisasi dan sistem pengendalian intern) adalah konstan, maka kecurangan cenderung menurun sebesar 9,401 menunjukkan nilai murni dari variabel kecurangan (dependen) tanpa dipengaruhi oleh variabel independen.

2. Koefisien regresi kompensasi karyawan $\left(\mathrm{X}_{1}\right)$ sebesar 0,391 berarti setiap peningkatan satu satuan variabel kompensasi karyawan, maka akan meningkatkan kecurangan sebesar 0,391 dengan asumsi variabel moralitas individu, keadilan organisasi dan sistem pengendalian intern adalah konstan.

3. Koefisien regresi moralitas individu $\left(\mathrm{X}_{2}\right)$ sebesar 0,302 berarti setiap peningkatan satu satuan variabel moralitas individu, maka akan meningkatkan kecurangan sebesar 0,302 dengan asumsi variabel kompensasi karyawan, keadilan organisasi dan sistem pengendalian intern adalah konstan. 
4. Koefisien regresi keadilan organisasi $\left(X_{3}\right)$ sebesar 0,169 berarti setiap peningkatan satu satuan variabel keadilan organisasi, maka akan meningkatkan kecurangan sebesar 0,169 dengan asumsi variabel kompensasi karyawan, moralitas individu, dan sistem pengendalian intern adalah konstan.

5. Koefisien regresi sistem pengendalian intern $\left(\mathrm{X}_{4}\right)$ sebesar 0,484 berarti setiap peningkatan satu satuan variabel sistem pengendalian intern, maka akan meningkatkan kecurangan sebesar 0,484 dengan asumsi variabel kompensasi karyawan, moralitas individu, dan keadilan organisasi.

\section{Uji Hipotesis}

\section{Uji Hipotesis Secara Simultan (Uji F)}

Uji statistik $F$ digunakan untuk mengetahui ada tidaknya pengaruh secara bersama-sama (simultan) variabel independen (bebas) yaitu Kompensasi Karyawan $\left(\mathrm{X}_{1}\right)$, Moralitas Individu $\left(\mathrm{X}_{2}\right)$, Keadilan Organisasi $\left(\mathrm{X}_{3}\right)$ dan Sistem Pengendalian Intern $\left(\mathrm{X}_{4}\right)$ terhadap variabel dependen (terikat) yaitu kecurangan $(\mathrm{Y})$. Uji $\mathrm{F}$ dilakukan dengan cara membandingkan nilai $\mathrm{F}$ hitung dengan $\mathrm{F}$ tabel pada tingkat kepercayaan $5 \%$ atau 0,05 , jika $\mathrm{F}$ hitung $>\mathrm{F}$ tabel maka Ho ditolak dan Ha diterima dimana $\mathrm{F}$ hitung diperoleh dari hasil output SPSS dalam Anova, sedangkan $\mathrm{F}$ tabel diperoleh dari (degree of freedom) $\mathrm{df}=\mathrm{n}-\mathrm{k}-1=49-4-1=44$, df pembilang $\mathrm{k}=4$, yaitu $F$ tabel $=2,58$. Hasil output SPSS untuk $F$ hitung disajikan pada tabel sebagai berikut :

\section{Tabel}

Hasil Uji Simultan (Uji F)

ANOVA $^{\mathrm{a}}$

\begin{tabular}{|ll|r|r|r|r|r|}
\hline Model & & Sum of Squares & Df & Mean Square & F & Sig. \\
\hline 1 & Regression & 472,016 & 4 & 118,004 & 22,864 &, $000^{\mathrm{b}}$ \\
& Residual & 227,086 & 44 & 5,161 & & \\
& Total & 699,102 & 48 & & & \\
\hline
\end{tabular}

a. Dependent Variable: Total Kecurangan

b. Predictors: (Constant), Total_Sistem_Pengendalian_Intern, Total_Moralitas_Individu,

Total_Kompensasi_Karyawan, Total_Keadilan_Organisasi

Sumber Data : Hasil Output SPSS 22.0

Dari Tabel Uji Anova (Analysis of Variance) didapat $\mathrm{F}$ hitung sebesar 22,864 dengan tingkat signifikansi sebesar $0,000<0.05$, dimana nilai $F$ hitung $(22,864)>$ nilai $\mathrm{F}$ tabel $(2,58)$ maka $\mathrm{Ha}$ diterima, dapat disimpulkan bahwa secara bersamasama ata secara simultan variabel kompensasi karyawan $\left(\mathrm{X}_{1}\right)$, moralitas individu $\left(\mathrm{X}_{2}\right)$, keadilan organisasi $\left(\mathrm{X}_{3}\right)$ dan sistem pengendalian intern $\left(\mathrm{X}_{4}\right)$ berpengaruh positif terhadap kecurangan (Y).

\section{Koefisien Determinasi (Uji Adjusted $\mathbf{R}^{\mathbf{2}}$ )}

Koefisien determinasi ( Adjusted $\mathrm{R}^{2}$ ) mengukur seberapa jauh kemampuan variabeli independen dalam menerangkan variabel dependen. Nilai koefisien determinasi adalah antara nol dan satu. Nilai $\mathrm{R}^{2}$ yang kecil berarti kemampuan variabel-variabel independen dalam menjelaskan variasi variabel dependen sangat terbatas. Nilai yang mendekati satu berarti variabel-variabel independen memberikan hampir semua informasi yang dibutuhkan untuk memprediksi variasi variabel dependen (Imam Ghozali, 2016:95). Hasil uji koefisien determinasi dapat dilihat dalam tabel sebagai berikut : 


\section{Tabel}

Hasil Uji Koefisien Determinasi $\left(\mathbf{R}^{2}\right)$

Model Summary

\begin{tabular}{|l|r|r|r|c|}
\hline Model & $\mathrm{R}$ & R Square & $\begin{array}{c}\text { Adjusted R } \\
\text { Square }\end{array}$ & $\begin{array}{c}\text { Std. Error of the } \\
\text { Estimate }\end{array}$ \\
\hline 1 &, $822^{\mathrm{a}}$ &, 675 &, 646 & 2,272 \\
\hline
\end{tabular}

a. Predictors: (Constant), Total_Sistem_Pengendalian_Intern,

Total_Moralitas_Individu, Total_Kompensasi_Karyawan,

Total_Keadilan_Organisasi

b. Dependent Variable: Total_Kecurangan

Sumber Data : Hasil Output SPSS 22.0

Berdasarkan tabel di atas didapatkan nilai Adjusted R Square sebesar 0,646 atau sama dengan $64,6 \%$. Hal tersebut menunjukkan bahwa variabel Kompensasi Karyawan $\left(X_{1}\right)$, Moralitas Individu $\left(X_{2}\right)$, Keadilan Organisasi $\left(X_{3}\right)$ dan Sistem Pengendalian Intern $\left(\mathrm{X}_{4}\right)$ berpengaruh terhadap Kecurangan $(\mathrm{Y})$ sebesar 64,6\%. Sedangkan sisanya sebesar $35,4, \%$ dipengaruhi oleh variabel lain yang belum diteliti dalam penelitian ini. Sehingga disimpulkan bahwa hubungan antara variabel bebas dan variabel terikat cukup kuat.

\section{Uji Hipotesis Secara Parsial (Uji t)}

Uji statistik t digunakan untuk mengetahui pengaruh setiap variabel bebas terhadap variabel terikat. Uji $t$ dilakukan dengan membandingkan antara $t$ hitung dengan $\mathrm{t}$ tabel., jika Jika $\mathrm{t}$ hitung $>\mathrm{t}$ tabel dapat disimpulkan bahwa terdapat pengaruh antara variabel independen terhadap variabel dependen atau sebaliknya, jika $t$ hitung $<\mathrm{t}$ tabel maka dapat disimpulkan bahwa tidak terdapat pengaruh antara variabel independen terhadap variabel dependen.

Untuk menentukan nilai $\mathrm{t}$ tabel ditentukan dengan tingkat signifikansi $5 \%$ atau 0,05 dengan derajat kebebasan (degree of freedom) df $=\mathrm{n}-\mathrm{k}-1=49-4-1=44$, $\mathrm{df}$ pembilang $\mathrm{k}=4(\mathrm{k})$ sehingga diperoleh untuk $\mathrm{t}$ tabel sebesar 2,01537 sedangkan untuk hasil $\mathrm{t}$ hitung dapat dilihat dari hasil output SPSS pada tabel Coeffisient sebagai berikut :

Tabel

Hasil Uji t - Uji Parsial Coefficients $^{\mathrm{a}}$

\begin{tabular}{|c|c|c|c|c|c|c|}
\hline \multirow[b]{2}{*}{ Mod } & & \multicolumn{2}{|c|}{$\begin{array}{l}\text { Unstandardized } \\
\text { Coefficients }\end{array}$} & \multirow{2}{*}{$\begin{array}{c}\text { Standardized } \\
\text { Coefficients } \\
\text { Beta }\end{array}$} & \multirow[b]{2}{*}{$\mathrm{T}$} & \multirow[b]{2}{*}{ Sig. } \\
\hline & & $\mathrm{B}$ & Std. Error & & & \\
\hline & (Constant) & $-9,401$ & 5,819 & & $-1,616$ &, 113 \\
\hline & Total_Kompensasi_Karyawan & ,391 &, 086 & ,427 & 4,548 &, 000 \\
\hline & Total_Moralitas_Individu & ,302 & ,138 & , 199 & 2,192 & ,034 \\
\hline & Total_Keadilan_Organisasi & , 169 & ,080 & , 199 & 2,104 &, 041 \\
\hline & Total_Sistem_Pengendalian_Intern & ,484 &, 130 & ,366 & 3,713 &, 001 \\
\hline
\end{tabular}

a. Dependent Variable: Total_Kecurangan

Sumber Data : Hasil Output SPSS 22.0

Berdasarkan tabel di atas selanjutnya peneliti melakukan pengujian hipotesis sebagai berikut : - Kompensasi Karyawan Berpengaruh Positif Signifikan terhadap 
Berdasarkan tabel Coefficients diperoleh dari t hitung variabel kompensasi karyawan sebesar 4,548 dengan tingkat signifikansi sebesar 0,000. Kemudian dibandingkan dengan $\mathrm{t}$ tabel sebesar 2,01537 ternyata nilai $\mathrm{t}$ hitung $(4,548)>\mathrm{t}$ tabel $(2,01537)$, sedangkan nilai signifikansi yang dihasilkan lebih kecil dari alpha $(\alpha)$ yakni $0,000<0,05$ maka $\mathrm{Ho}_{1}$ ditolak dan $\mathrm{Ha}_{1}$ diterima, artinya bahwa kompensasi karyawan secara parsial berpengaruh positif signifikan terhadap kecurangan sebesar 0,391 atau 39,1\%.

- Moralitas Individu Berpengaruh Positif Signifikan terhadap Kecurangan Berdasarkan tabel Coefficients diperoleh dari t hitung variabel moralitas individu sebesar 2,192 dengan tingkat signifikansi sebesar 0,034. Kemudian dibandingkan dengan $t$ tabel sebesar 2,01537, ternyata nilai $t$ hitung $(2,192)>t$ tabel $(2,01537)$, sedangkan nilai signifikansi yang dihasilkan lebih kecil dari alpha $(\alpha)$ yakni $0,034<0,05$ maka $\mathrm{Ho}_{2}$ ditolak dan $\mathrm{Ha}_{2}$ diterima, artinya bahwa Moralitas Individu secara parsial berpengaruh positif signifikan terhadap kecurangan sebesar 0,302 atau 30,2\%.

- Keadilan Organisasi Berpengaruh Positif Signifikan terhadap Kecurangan

Berdasarkan tabel Coefficients diperoleh dari $\mathrm{t}$ hitung variabel keadilan organisasi sebesar 2,104 dengan tingkat signifikansi sebesar 0,041. Kemudian dibandingkan dengan $\mathrm{t}$ tabel sebesar 2,01537 ternyata nilai $\mathrm{t}$ hitung $(2,104)>\mathrm{t}$ tabel $(2,01537)$, sedangkan nilai signifikansi yang dihasilkan lebih kecil dari alpha $(\alpha)$ yakni $0,041<0,05$ maka $\mathrm{Ho}_{3}$ ditolak dan $\mathrm{Ha}_{3}$ diterima, artinya bahwa keadilan organisasi secara parsial berpengaruh positif signifikan terhadap kecurangan sebesar 0,169 atau 16,9\%.

- Sistem Pengendalian Intern Berpengaruh Positif Signifikan terhadap Kecurangan

Berdasarkan tabel Coefficients diperoleh dari $t$ hitung variabel sistem pengendalian intern

sebesar 3,713 dengan tingkat signifikansi sebesar 0,001. Kemudian dibandingkan dengan $\mathrm{t}$ tabel sebesar 2,01537, ternyata nilai $\mathrm{t}$ hitung $(3,713)>\mathrm{t}$ tabel $(2,01537)$, sedangkan nilai signifikansi yang dihasilkan lebih kecil dari alpha $(\alpha)$ yakni $0,001<0,05$ maka $\mathrm{Ho}_{4}$ ditolak dan $\mathrm{Ha}_{4}$ diterima, artinya bahwa sistem pengendalian intern secara parsial berpengaruh positif signifikan terhadap kecurangan sebesar 0,484 atau 48,4\%.

\section{Interpretasi Hasil Penelitian}

Kompensasi Karyawan Berpengaruh Positif Signifikan terhadap Kecurangan

Dengan demikian hasil penelitian ini menunjukkan bahwa semakin tinggi kompensasi yang diberikan oleh perusahaan kepada karyawan maka dapat membuat terjadinya kecurangan semakin meningkat. Begitu dengan sebaliknya apabila kompensasi yang diberikan oleh perusahaan kepada karyawan menurun maka dapat membuat terjadinya kecurangan akan menurun. Hal ini terjadi karena faktor keserakahan (greeds) yang diartikan sebagai perilaku serakah yang secara potensial ada di dalam diri setiap orang. Walaupun kompensasi karyawan yang diberikan sudah terpenuhi dengan baik, kenyataannya karyawan berpotensi melakukan kecurangan karena karyawan tersebut belum puas dengan apa yang diberikan oleh perusahaan. 
Hasil penelitian ini sejalan dengan hasil penelitian sebelumnya yang dilakukan oleh Ida Bagus Komang Suarcaya, Made Aristia Prayudi dan Nyoman Trisna Herawati (2017), Benedicta Mega Haryanti D dan Muhammad Nuryanto (2018) yang menyatakan bahwa terdapat pengaruh signifikan kompensasi karyawan terhadap kecurangan. Namun hasil penelitian ini tidak sejalan dengan hasil penelitian Deni Ahriati (2015), Adrian Bartenputra (2016), dan Fera (2018) bahwa tidak terdapat pengaruh kesesuaian kompensasi terhadap kecurangan. Perbedaan tersebut diduga karena objek penelitian yaitu pada SKPD Kota Bukit Tinggi.

\section{Moralitas Individu Berpengaruh Positif Signifikan terhadap Kecurangan}

Hasil penelitian ini menunjukkan bahwa semakin baik tingkat moral seseorang maka dapat meningkatkan terjadinya kecurangan. Begitu dengan sebaliknya apabila tingkat moral seseorang buruk maka dapat menurunkan terjadinya kecurangan. Hal ini terjadi karena faktor keserakahan (greeds) yang diartikan sebagai perilaku serakah yang secara potensial ada di dalam diri setiap orang. Tingkat moral individu yang baik belum menjamin individu tersebut tidak melakukan kecurangan, kenyataannya individu yang memiliki moral yang baik juga berpotensi melakukan kecurangan karena individu tersebut merasa belum puas terhadap apa yang diberikan oleh perusahaan.

Hasil penelitian ini sejalan dengan hasil penelitian sebelumnya yang dilakukan oleh Gede Krisna Saputra (2015), Ranti Melasari (2016) disimpulkan bahwa moralitas individu berpengaruh signifikan terhadap kecurangan (fraud). Namun hasil penelitian ini tidak sejalan dengan hasil penelitian M. Harry Krishna Mulia (2017), Nanda Amalia Agnia Salahudin (2018) dan Fera (2018) menunjukkan bahwa moralitas individu tidak berpengaruh terhadap kecenderungan kecurangan akuntansi. Perbedaan tersebut diduga karena objek penelitian yang dilakukan yaitu mahasiswa/I pada Universitas, Keuangan garment, dan bagian keuangan kantor Walikota Jakarta Barat.

\section{Keadilan Organisasi Berpengaruh Positif Signifikan terhadap Kecurangan}

Hasil penelitian ini menunjukkan bahwa semakin tinggi tingkat keadilan organisasi di dalam perusahaan maka akan meningkatkan terjadinya kecurangan. Begitu dengan sebaliknya apablia tingkat keadilan organisasi di dalam perusahaan menurun maka akan menurunkan terjadinya kecurangan. Hal ini terjadi karena faktor keserakahan (greeds) yang diartikan sebagai perilaku serakah yang secara potensial ada di dalam diri setiap orang. Karyawan yang diperlakukan secara adil ditempat mereka bekerja belum menjamin karyawan tersebut tidak melakukan kecurangan, kenyataannya karyawan berpotensi melakukan kecurangan karena karyawan tersebut belum puas dengan apa yang diberikan oleh perusahaan.

Hasil penelitian ini sejalan dengan hasil penelitian sebelumnya yang dilakukan oleh Lisa Amelia Herman (2013), Jelfani Saragih (2017) yang menunjukkan bahwa keadilan organisasi berpengaruh signifikan terhadap kecurangan. Namun hasil penelitian ini tidak sejalan dengan hasil penelitian Irmaya Sitarahmi (2016), Nanda Amalia Agnia Salahudin (2018) menunjukkan bahwa keadilan organisasional tidak berpengaruh secara signifikan terhadap kecurangan karyawan. Perbedaan tersebut diduga karena objek penelitian yang dilakukan yaitu pada Kantor Cabang Utama Bank Pemerintah dan Pada Perusahaan Gerai Minimarket di Kota Semarang. 


\section{Sistem Pengendalian Intern Berpengaruh Positif Signifikan terhadap Kecurangan}

Hasil penelitian ini menunjukkan bahwa semakin baik sistem pengendalian intern di dalam suatu perusahaan maka akan meningkatkan kecurangan. Begitu dengan sebaliknya semakin buruk sistem pengendalian intern di dalam suatu perusahaan maka akan menurunkan terjadinya kecurangan. Hal ini terjadi karena faktor keserakahan (greeds) yang diartikan sebagai perilaku serakah yang secara potensial ada di dalam diri setiap orang. Sistem pengendalian intern memiliki pengaruh yang besar terhadap kelangsungan perusahaan, dengan sistem pengendalian yang baik, maka perusahaan dapat melaksanakan seluruh aktifitasnya sesuai dengan tujuan dan sasaran yang ingin dicapai. Sistem pengendalian intern yang baik belum menjamin karyawan tidak melakukan kecurangan, kenyataannya karyawan berpotensi melakukan kecurangan karena karyawan tersebut belum puas dengan apa yang diberikan oleh perusahaan.

Hasil penelitian ini sejalan dengan hasil penelitian sebelumnya yang dilakukan oleh Lisa Amelia Herman (2013), Ranti Melasari (2016), M. Harry Krishna Mulia 2017) yang menunjukkan bahwa pengendalian internal berpengaruh signifikan terhadap kecurangan. Namun hasil penelitian ini tidak sejalan dengan hasil penelitian Deni Ahriati (2015), Nanda Amalia Agnia Salahudin (2018) menunjukkan bahwa tidak terdapat pengaruh pengendalian internal terhadap kecenderungan kecurangan akuntansi. Perbedaan tersebut diduga karena objek penelitian yang dilakukan yaitu pada Pemerintah Daerah Kabupaten Lombok Timur dan bagian keuangan Kantor Walikota Jakarta Barat.

\section{Kompensasi Karyawan, Moralitas Individu, Keadilan Organisasi dan Sistem Pengendalian Intern Berpengaruh Simultan terhadap Kecurangan.}

Berdasarkan nilai Adjusted R Squaresebesar 0,646 atau sama dengan 64,6\%. Hal tersebut menunjukkan bahwa sebesar $64,6 \%$ pengaruh Kecurangan (Y) dapat dijelaskan oleh variabel Kompensasi Karyawan $\left(\mathrm{X}_{1}\right)$, Moralitas Individu $\left(\mathrm{X}_{2}\right)$, Keadilan Organisasi $\left(\mathrm{X}_{3}\right)$ dan Sistem Pengendalian Intern $\left(\mathrm{X}_{4}\right)$. Sedangkan sisanya sebesar 35,4\% dipengaruhi oleh variabel lain yang belum diteliti dalam penelitian ini. Sehingga disimpulkan bahwa hubungan antara variabel bebas dan variabel terikat cukup kuat.

\section{KESIMPULAN DAN SARAN}

\section{Kesimpulan}

Berdasarkan hasil penelitian ini mengenai pengaruh kompensasi karyawan, moralitas individu, keadilan organisasi, dan sistem pengendalian intern terhadap kecurangan menggunakan analisis regresi linear berganda, maka dapat diambil kesimpulan sebagai berikut :

1. Hasil penelitian ini menunjukkan bahwa Kompensasi Karyawan berpengaruh positif signifikan terhadap Kecurangan.

2. Hasil penelitian ini menunjukkan bahwa Moralitas Individu berpengaruh positif signifikan terhadap Kecurangan.

3. Hasil penelitian ini menunjukkan bahwa Keadilan Organisasi berpengaruh positif signifikan terhadap Kecurangan. 
4. Hasil penelitian ini menunjukkan bahwa Sistem Pengendalian Intern berpengaruh positif signifikan terhadap Kecurangan

5. Hasil penelitian ini menunjukkan bahwa Kompensasi Karyawan, Moralitas Individu, Keadilan Organisasi dan Sistem Pengendalian Intern secara bersama-sama berpengaruh simultan terhadap Kecurangan.

\section{Saran}

Adapun saran dalam penelitian ini ada dua hal, yaitu bagi perusahaan dan bagi peneliti lanjutan, dijelaskan sebagai berikut :

\section{Bagi Perusahaan}

Adapun hasil penelitian ini menunjukkan analisis pengaruh kompensasi karyawan, moralitas individu, keadilan organisasi dan sistem pengendalian intern terhadap kecurangan, saran dari penelitian ini adalah sebagai berikut :

a. Perusahaan diharapkan dapat meningkatkan pemberian kompensasi kepada karyawannya.

b. Perusahaan diharapkan lebih memperhatikan karyawannya dengan cara memberikan arahan mengenai pemahaman kode etik perbankan dan melaksakan peraturan-peraturan yang berlaku di perusahaan.

c. Perusahaan diharapkan dapat memberikan perlakuan yang adil di dalam organisasi agar tercipta lingkungan kerja yang kondusif dan tidak ada kecemburuan antar sesama karyawan.

d. Perusahaan diharapkan dapat mempertahankan dan meningkatkan sistem pengendalian intern yang lebih baik mengingat teknologi yang digunakan pada perusahaan perbankan saat ini semakin canggih sehingga perlu adanya sistem pengendalain intern yang baik.

\section{Bagi Peneliti Lanjutan}

Peneliti selanjutnya diharapkan dapat memperbaiki kekurangan penelitian ini diantaranya sebagai berikut :

1. Peneliti selanjutnya diharapkan dapat melakukan penelitian dengan objek penelitian yang berbeda, misalnya perusahaan yang bergerak dibidang lainnya bukan hanya bidang perbankan saja.

2. Peneliti selanjutnya diharapkan dapat menambah variabel lain mengingat banyak faktor yang dapat memperngaruhi terjadinya kecurangan seperti kepuasan kerja, tekanan, asimetri informasi, kompetensi dan lainnya sebagainya.

3. Peneliti selanjutnya diharapkan dapat menambah jumlah responden dengan lingkup objek penelitan yang lebih besar dan waktu yang cukup sehingga dapat diperoleh data dan hasil analisis yang lebih akurat.

\section{DAFTAR PUSTAKA}

Ahriati, D., Basuki, P., \& Widiastuty, E. (2015). Analisis Pengaruh Sistem Pengendalian Internal, Asimetri Informasi, Perilaku Tidak Etis dan Kesesuaian Kompensasi Terhadap Kecenderungan Kecurangan Akuntansi Pada Pemerintah Daerah Kabupaten Lombok Timur. InFestasi (Jurnal Bisnis dan Akuntansi), 11(1), 41-55. 
Dibyopranoto, B. M. H \& Nuryanto M. (2018). Pengaruh Kompensasi Karyawan dan Kepuasan Kerja Terhadap Kecenderungan Kecurangan Perbankan. Jurnal. Universitas Trisakti Indonesia.

Fera (2018). Pengaruh Efektivitas Pengendalian Internal, Moralitas Individu, Kesesuaian Kompensasi, Dan Asimetri Informasi Terhadap Kecenderungan Kecurangan Akuntansi (Studi Empiris pada Karyawan Divisi Keuangan dan Garment PT. Dan Liris Kabupaten Sukoharjo) (Doctoral dissertation, Universitas Muhammadiyah Surakarta).

Ghozali, Imam. 2016. Aplikasi Analisis Multivariate Dengan Program IBM SPSS 23. Semarang: Badan Penerbit Universitas Diponogoro.

Herman, L. A. (2013). Pengaruh Keadilan Organisasi dan Sistem Pengendalian Intern Terhadap Kecurangan (Studi Empiris Pada Kantor Cabang Utama Bank Pemerintah di Kota Padang). Jurnal Akuntansi, 1(1).

Hery, 2017. Auditing Dan Asurans, Integrated And Comprehensive Edition. Jakarta: Grasindo.

Ikatan Bankir Indonesia. Profil Ikatan Bankir Indonesia. Diakses pada tanggal 11/05/2020, 22:05 WIB. https://ikatanbankir.or.id/profil-ikatan-bankir-indonesia-ibi/

Kadarisman, M. 2016. Manajemen Kompensasi. Jakarta: PT. Rajagrafindo Persada.

Melasari, R. (2016). Pengaruh Moralitas Individu dan Pengendalian Internal Terhadap Kecenderungan Kecurangan Akuntansi Pada Perbankan di Tembilahan. Jurnal Akuntansi dan Keuangan, 5(2).

Meliana, M., \& Hartono, T. R. (2019). Fraud Perbankan Indonesia: Studi Eksplorasi. In Prosiding Seminar Nasional Pakar (pp. 2-52).

Muhammad, R., \& Ibrahim, R. (2017). Pengaruh Kesesuaian Kompensasi, Penerapan Sistem Informasi Akuntansi, dan Efektivitas Pengendalian Internal Terhadap Kecurangan Akuntansi Studi Pada Bank Perkreditan Rakyat (BPR) di Kota Banda Aceh. Jurnal Ilmiah Mahasiswa Ekonomi Akuntansi, 2(4), 136-145.

Mulia, M. H. K., Febrianto, R., \& Kartika, R. (2017). Pengaruh Moralitas Individu dan Pengendalian Internal terhadap Kecurangan: Sebuah Studi Eksperimental. Journal of Accounting and Investment, 18(2), 198-208.

Priantara, Diaz. 2013. Fraud Auditing \& Investigation. Jakarta: Mitra Wacana Media.

Rahmat, A. (2018). Moralitas dan Pengendalian Internal dalam Kecenderungan Kecurangan Akuntansi (Studi Eksperimen Pada Konteks Perguruan Tinggi Negeri-BLU). Jurnal Akuntansi, 6(3).

Riduwan dan Engkos Achmad Kuncoro, 2012. Cara menggunakan dan Memakai Path Analysis (Analisis Jalur). Bandung: CV Alfabeta.

Santoso, Agus, 2012. Hukum, Moral \& Keadilan. Jakarta: Prenada Media.

Saputra, G. K., Darmawan, N. A. S., SE, A., \& Purnamawati, I. G. A. (2015). Pengaruh Pengendalian Intern Kas, Implementasi Good Governance dan Moralitas Individu Terhadap Kecurangan (Fraud) (Studi Empiris Pada LPD di Kabupaten Buleleng Bagian Timur). JIMAT (Jurnal Ilmiah Mahasiswa Akuntansi) Undiksha, 3(1).

Segoro, Waseso, 2017. Manajemen Sumber Daya Manusia: Pendekatan Teoritis dan Praktis. Yogyakarta: Deepublish. 
Setiawan, M. D., Adiputra, I. M. P., SE, S., Yuniarta, G. A., \& AK, S. (2015). Pengaruh Sistem Pengendalian Intern, Asimetri Informasi, dan Keadilan Organisasi terhadap Kecurangan (Fraud) (Studi empiris pada Bank Perkreditan Rakyat Se-Kabupaten Buleleng). JIMAT (Jurnal Ilmiah Mahasiswa Akuntansi) Undiksha, 3(1).

Sitarahmi, I. (2016). Pengaruh Keadilan Organisasional Terhadap Kecurangan dengan Variabel Moderating Kualitas Pengendalian Internal. Jurnal Ilmu Manajemen dan Akuntansi Terapan (JIMAT), 7(2), 78-89.

Suarcaya, I. B. K., Prayudi, M. A., Herawati, N. T., \& Ak, S. E. (2018). Pengaruh Kesesuaian Kompensasi, Pengendalian Internal, dan Perilaku Tidak Etis Terhadap Kecenderungan Kecurangan (Fraud) (Studi Kasus Pada Persepsi Pegawai Koperasi Simpan Pinjam (KSP) Se-kecamatan Buleleng). JIMAT (Jurnal Ilmiah Mahasiswa Akuntansi) Undiksha, 8(2).

Sugiyono, 2016. Metode Penelitian Kuantitatif, Kualitatif dan R\&D. Bandung: Alfabeta.

Sumbayak, J. S., Anisma, Y., \& Hasan, M. A. (2017). Pengaruh Keadilan Organisasi, Sistem Pengendalian Intern, Komitmen Organisasi dan Gaya Kepemimpinan Terhadap Kecurangan (Fraud) (Studi Empiris Pada Kantor Cabang Utama Perusahaan Leasing Di Kota Pekanbaru) (Doctoral Dissertation, Universitas Riau).

Wati, C., \& Puspitasari, W. (2019). Pengaruh Fraud Diamond, Corporate Governance, dan Kompleksitas Bank Terhadap Financial Statement Fraud Pada Perusahaan Perbankan. Jurnal Akuntansi Trisakti, 4(2), 157-168.

Yuliana, A., Satriawan, S., Adri, R., \& Hariyani, E. (2016). Pengaruh Keadilan Organisasi, Sistem Pengendalian Intern dan Komitmen Organisasi Terhadap Kecurangan (Fraud) (Studi Empiris Pada Kantor Cabang Utama Bank Syariah Di Kota Pekanbaru) (Doctoral Dissertation, Universitas Riau. 


\title{
PENGARUH AUDIT TENURE, REPUTASI AUDITOR DAN \\ UKURAN PERUSAHAAN, TERHADAP OPINI AUDIT GOING \\ CONCERN (STUDI EMPIRIS PADA PERUSAHAAN \\ MANUFAKTUR SUB SEKTOR MAKANAN DAN MINUMAN \\ PADA TAHUN 2014-2018)
}

\author{
Adolpino Nainggolan, SE, M.Ak \\ Heriston Sianturi, SE, MM
}

adolpino_nainggolan@yahoo.co.id, bertonray@gmail.com

\section{Fakultas Ekonomi dan Bisnis - Program Studi Akuntansi Universitas Satya Negara Indonesia}

\begin{abstract}
ABSTRAK
Tujuan penelitian ini adalah untuk mengetahui pengaruh audit tenure, reputasi auditor dan ukuran perusahaan terhadap opini going concern. Populasinya adalah perusahaan manufaktur sub sektor makanan dan minuman yang terdaftar di BEI pada tahun 2014 hingga 2018. Metode pengambilan sampel adalah Purposive Sampling. Teknik analisis yang digunakan dalam penelitian ini adalah analisis regresi logistik. Hasil penelitian secara parsial audit tenure tidak berpengaruh terhadap opini going concern, sedangkan reputasi auditor dan ukuran perusahaan berpengaruh terhadap opini audit going concern. Secara simultan variabel audit tenure, reputasi auditor dan ukuran perusahaan berpengaruh terhadap opini going concern sebesar 45,80\%, sedangkan sisanya sebesar 54,20\% dipengaruhi oleh variabel lainnya yang tidak termasuk penelitian ini.
\end{abstract}

Kata Kunci: Audit Tenure, Reputasi Auditor, Ukuran Perusahaan, danOpini Audit Going Concern 


\section{PENDAHULUAN}

Perusahaan didirikan dengan tujuan untuk mempertahankan kelangsungan hidup (going concern). Kelangsungan hidup usaha selalu dihubungkan dengan kemampuan manajemen memperoleh laba agar perusahaan tersebut dapat mempertahankan kelangsungan hidup (going concern). Bentuk pertangungjawaban manajemen dalam mengelola perusahaan ditunjukkan dalam bentuk laporan keuangan. Laporan keuangan memberikan gambaran mengenai posisi kinerja perusahaan, dan perubahan posisi keuangan. Agar laporan keuangan tersebut dapat dipercaya, maka dibutuhkan laporan auditan yang diterbitkan oleh Kantor Akuntan Publik (KAP) dalam bentuk opini audit. Laporan auditan tersebut berperan dalam menjembatani kepentingan pengguna laporan keuangan dan penyedia laporan keuangan (Wulandari, 2014).

Salah satu opini yang bisa diberikan auditor adalah opini going concern. Opini going concern merupakan opini yang diterima oleh suatu perusahaan yang menunjukan adanya kondisi dan peristiwa yang menimbulkan keraguan auditor akan kelangsungan hidup perusahaan atau kemampuan entitas untuk mempertahankan kelangsungan hidupnya (Rizki dan Indah, 2014).

Opini going concern dapat dipengaruhi masa perikatan audit (audit tenure) antara suatu perusahaan dengan KAP. Apabila masa perikatan yang dilakukan dalam waktu lama akan membuat kedekatan antara klien dengan auditor, sehingga independensi dan objektivitas auditor nantinya akan terpengaruh. Pernyataan tersebut serupa dengan penilitian Al- Thuneibat et al,. (2011) yang menyatakan masa perikatan cukup lama dapat mempengaruhi independnsi dan objektivitas auditor dalam memberikan opini.

Pemberian opini going concern bukanlah suatu tugas yang mudah karena berkaitan erat dengan reputasi auditor. Penghakiman terhadap KAP sering dilakukan, baik oleh masyarakat maupun pemerintah dengan melihat kondisi bangkrut atau tidaknya perusahaan yang diaudit. Hal ini berarti reputasi sebuah KAP dipertaruhkan ketika opini yang diberikan ternyata tidak sesuai dengan kondisi perusahaan yang sesungguhnya. Auditor harus mempunyai keberanian dalam mengungkapkan permasalahan mengenai kelangsungan hidup (going concern) perusahaan klien. Auditor bertanggung jawab mengevaluasi apakah terdapat kesangsian besar terhadap kemampuan entitas dalam mempertahankan kelangsungan hidupnya dalam periode waktu pantas (Bonita Riestianiko, 2017).

Faktor lain yang mempengaruhi opini going concern adalah ukuran perusahaan. Ukuran perusahaan menggambarkan besar kecilnya suatu perusahaan yang pada umumnya ditentukan berdasarkan total asset (Seftianne, 2011), semakin besar ukuran perusahaan, maka semakin meningkat pula agency cost yang terjadi, hal ini dapat terjadi karena besarnya total asset perusahaan kecenderungan diperoleh dari pinjaman jangka panjang, dimana beban bunga pinjaman tersebut dapat mempengaruhi kemampuan perusahaan untuk mempertahankan kelangsungan hidupnya

Beberapa penelitian telah dilakukan oleh peniliti sebelumnya, namun, hasilnya masih menunjukkan ketidak konsistenan. Hasil penelitian yang dilakukan oleh Fauzan Syahputra dan M. Rizal Yahya (2017) audit tenur berpengaruh terhadap opini going concern, sedangkan penelitian M. Nur Fahmi (2015) ) audit tenur tidak berpengaruh terhadap opini going concern 
Hasil penelitian Fitria Octari Hidayanti dan Sukirman (2014) reputasi auditor berpengaruh terhadap opini going concern, sedangkan penelitian Anindya Sekar Ayu Miraningtyas dan Yudowati, S. (2019) reputasi auditor tidak berpengaruh terhadap opini going concern.

Hasil penelitian yang dilakukan oleh Ginting dan Linda (2014) ukuran perusahaan berpengaruh terhadap opini going concern, sedangkan penelitian Monica Krissindiastuti dan Ni Ketut Rasmini (2016) menunjukan ukuran perusahaan tidak berpengaruh terhadap opini going concern.

Femomena tersebut yang membuat peneliti teretarik untuk melakukan penelitian selanjutnya tentang Pengaruh Audit Tenur, Reputasi Auditor dan Ukuran Perusahaan Terhadap Opini Audit Going Concern

\section{LANDASAN TEORI}

\section{Opini Audit Going Concern}

Opini audit going concern merupakan opini audit modifikasi yang diberikan auditor bila terdapat keraguan atas kemampuan kelangsungan hidup (going concern) perusahaan atau terdapat ketidakpastian yang signifikan atas kelangsungan hidup perusahaan dalam menjalankan operasinya dalam kurun waktu yang pantas, tidak lebih dari satu tahun sejak tanggal pelaporan keuangan yang sedang diaudit (SPAP,2016).

\section{Audit Tenure}

Audit tenure adalah jangka waktu kerja sama yang terjalin diantara KAP dengan klien yang sama. Ketakutan akan kehilangan sejumlah bayaran yang cukup besar akan memicu keraguan bagi auditor untuk memberikan opini audit going concern. Di Indonesia peraturan audit tenure telah diatur didalam Peratuan Pemerintah (PP) Nomor 20/2015 Pasal 11. Peraturan ini menjelaskan bahwa pemberian jasa audit umum atas laporan keuangan dari suatu entitas dilakukan oleh KAP paling lama untuk 5 tahun buku berturut-turut. Auditor dapat menerima kembali penugasan audit untuk klien tersebut setelah 2 tahun buku tidak memberikan jasa audit umum atas laporan keuangan klien tersebut.

\section{Reputasi Auditor}

Reputasi auditor merupakan dimana auditor bertanggungjawab untuk tetap menjaga kepercayaan publik dan menjaga nama baik auditor sendiri serta KAP tempat auditor tersebut bekerja dengan mengeluarkan opini yang sesuai dengan keadaan perusahaan yang sebenarnya (Verdiana dan Utama, 2013). Menurut penelitian Badera dan Rudyawan, 2009 dalam Putri, 2014 reputasi auditor merupakan prestasi dan kepercayaan publik yang disandang auditor atas nama besar yang dimiliki auditor tersebut.

Dalam penelitian ini reputasi auditor masih diproksikan dengan The Big 4, karena KAP The Big Four berpengaruh terhadap hasil audit dan lebih banyak mendapatkan kepercayaan dari investor (Praptorini dan Januarti, 2007 dalam Ni Made Puspa Pawitri dan Ketut Yadnyana, 2015).

Alasan KAP The Big Four lebih dipercaya dikarenakan KAP The Big Four dianggap memiliki reputasi yang lebih baik dibandingkan dengan KAP Non Big Four dan memiliki sumber daya yang lebih besar dibandingkan dengan KAP Non 
Big Four, sehingga dalam dalam melaksanakan audit KAP The Big Four cenderung lebih efisien dan efektif dan memiliki jadwal untuk menyelesaikan audit tepat waktu, guna menjaga reputasinya. (Praptorini dan Januarti, 2007 dalam Ni Made Puspa Pawitri dan Ketut Yadnyana, 2015). ). KAP The Big Four terdiri dari:

a. Deloitte Touche Tohmatsu, yang bekerja sama dengan Satrio Bing Ery dan Rekan serta Hermawan Juniarto \& Partners

b. Price Waterhouse Coopers, yang bekerja sama dengan Tanudiredja, Wibisana \& Rekan.

c. Ernst \& Young, yang bekerja sama dengan Purwantono, Suherman dan Surja.

d. KPMG (Klynveld Peat Marwick Goerdeler), yang bekerja sama dengan KAP Siddharta dan Widjaja.

\section{Ukuran Perusahaan}

Ukuran adalah Suatu skala dimana dapat diklasifikasikan besar kecilnya perusahaan menurut berbagai cara antara lain dengan total aset, nilai pasar saham, dan lain-lain. (Hery, 2017). Besar kecilnya perusahaan akan mempengaruhi kemampuan dalam menanggung resiko yang mungkin timbul dari segala situasi yang dihadapi perusahaan. Dimana perusahaan dengan skala besar cenderung dianggap lebih mampu mengatasi resiko-resiko yang ada. Ukuran perusahaan dapat dinilai dari total aset. Nilai aset dapat menunjukan kekayaan yang dimiliki perusahaan dalam menjalankan kegiatan operasionalnya. Ukuran perusahaan dapat dilihat dari seberapa besar atau kecil usaha yang dilakukan perusahaan. Perusahaan dengan skala besar dan pertumbuhan yang positif memberikan tanda bahwa semakin kecil kemungkinan perusahaan akan bangkrut dan dianggap mampu mempertahankan kelangsungan usahanya.

\section{METODE PENELITIAN}

\section{Desain Penelitian}

Desain penelitian yang dilakukan adalah Penelitian Kausal (Causal Research). Penelitian kausal adalah penelitian yang bersifat sebab akibat. Digunakan untuk mengetahui pengaruh antara satu atau lebih variabel bebas (Independent Variable) terhadap variabel terikat (Dependent Variable).

\section{Populasi dan Sampel}

Populasi yang digunakan dalam penelitian ini adalah perusahaan go public yang terdaftar di Bursa Efek Indonesia (BEI) dibidang manufaktur sub sektor makanan dan minuman pada tahun 2014-2018. Pengambilan sampel dalam penelitian ini menggunakan purposive sampling, Metode purposive sampling adalah teknik penentuan sampel dengan pertimbangan beberapa kriteria tertentu (Sugiyono, 2017:124).

\section{Tabel 1}

Jumlah Sampel

\begin{tabular}{|c|l|c|}
\hline No. & \multicolumn{1}{|c|}{ Kriteria } & Jumlah Perusahaan \\
\hline 1 & $\begin{array}{l}\text { Total perusahaan manufaktur sub sektor makanan dan } \\
\text { minuman yang terdaftar di BEI pada tahun 2014 sampai } \\
\text { dengan 2018. }\end{array}$ & 28 \\
\hline
\end{tabular}

Jurnal Ilmiah Akuntansi dan Ekonomi Volume. 5 Nomor. 2, Agustus 2020 Hal. 78 


\begin{tabular}{|c|l|c|}
\hline 2 & $\begin{array}{l}\text { Perusahaan yang tidak konsisten menerbitkan laporan } \\
\text { keuangan dari tahun 2014 sampai dengan 2018 dan tidak } \\
\text { diaudit oleh auditor independen. }\end{array}$ & (13) \\
\hline Jumlah Sampel Perusahaan & 15 \\
\hline Tahun Penelitian & 75 \\
\hline Jumlah Sampel Data Selama Tahun Penelitian & 5 \\
\hline
\end{tabular}

Sumber : Data diolah

\section{Teknik Pengumpulan Data}

Penelitian ini termasuk dalam penelitian kuantitatif dengan menggunakan data sekunder berupa laporan keuangan sebagai sumber data. Data sekunder yang diambil dalam penelitian ini adalah laporan keuangan perusahaan manufaktur yang terdaftar di Bursa Efek Indonesia (BEI) yang telah diudit oleh Kantor Akuntan Publik (KAP). Penggunaan laporan keuangan dalam penelitian ini adalah untuk mengukur pengaruh audit tenure, reputasi auditor, dan ukuran perusahaan terhadap penerimaan opini audit going concern.

\section{Operasional Variabel dan Skala pengukuran Variabel dependen}

Variabel dependen dalam penelitian ini adalah opini audit going concern. Opini audit going concern diukur dengan menggunakan dummy. Perusahaan yang mendapat opini going concern diberi kode 1, sedangkan perusahaan yang tidak mendapat opini going concern diberi kode 0. (Krissindiastuti dan Ni Ketut Rasmini, 2016).

\section{Variabel Independen}

\section{a. Audit Tenure}

Audit tenure diukur dengan menghitung tahun dimana KAP yang sama telah melakukan perikatan dengan auditee. Audit tenure memiliki nilai maksimum 5 sebagaimana telah diatur dalam Peraturan Pemerintah Republik Indonesia Nomor 20/2015 Pasal 11 bahwa lamanya perikatan audit antara KAP dan perusahaan paling lama selama 5 tahun berturut-turut.

Audit tenure diukur dengan menggunakan dummy. Perusahaan yang telah berganti Kantor Akuntan Publik (KAP) diberi kode 1, sedangkan perusahaan yang tidak berganti Kantor AKuntan Publik (KAP) diberi kode 0

\section{b. Reputasi Auditor}

Reputasi auditor merupakan dimana auditor bertanggungjawab untuk tetap menjaga kepercayaan publik dan menjaga nama baik auditor sendiri serta KAP tempat auditor tersebut bekerja dengan mengeluarkan opini yang sesuai dengan keadaan perusahaan yang sebenarnya (Verdiana dan Utama, 2013). Dalam penelitian ini reputasi auditor diproksikan dengan The Big Four, karena KAP The Big Four lebih banyak mendapatkan kepercayaan dari investor (Praptorini, 2007 dalam Ni Made Puspa Pawitri dan Ketut Yadnyana,(2015

Reputasi Auditor diukur menggunakan dummy, perusahaan yang menggunakan KAP The Big Four diberi Kode 1, sedangkan perusahaan yang tidak menggunakan KAP The Big Four diberi Kode 0. 


\section{c. Ukuran Perusahaan}

Ukuran perusahaan merupakan skala yang dapat mengklasifikasikan perusahaan menjadi perusahaan besar, menengah dan kecil. Total aset yang dipilih sebagai proksi atas ukuran perusahaan karena mempertimbangkan bahwa nilai aset relatif lebih stabil nilai kapitalisasi pasar dan penjualan (Azizah dan Aniskyurillah, 2014). Dalam penelitian ini ukuran perusahaan diproksikan dengan menggunakan Ln total aset. Penggunaan logaritma natural (Ln) untuk mengurangi digit data terlalu besar akan tetapi tidak mengurangi nilai yang sebenarnya.

Ukuran Perusahaan $=$ Ln Total Aset

\section{Metode Analisis Data}

Analisis data yang dilakukan dengan menggunakan analisis regresi logistik dan pengujian hipotesis dilakukan sesuai dengan rancangan pengujian hipotesis yang telah dibuat. Data diolah dengan menggunakan program IBM StatisticalPackage for Social Science (SPSS) versi 22.

\section{ANALISIS DAN PEMBAHASAN}

\section{Pengujian Hipotesis Parsial}

Tabel 2

Variables in the Equation

\begin{tabular}{|ll|r|r|r|r|r|r|}
\hline & \multicolumn{1}{|c|}{ B } & \multicolumn{1}{c|}{ S.E. } & Wald & df & Sig. & Exp(B) \\
\hline Step 1a & AT &,- 315 &, 368 &, 782 & 1 &, 436 &, 614 \\
& RA &, 594 &, 374 & 3,786 & 1 &, 038 &, 486 \\
UP & 1,281 &, 890 & 7,612 & 1 &, 006 & 12,131 \\
Constant & 6,427 & 11,894 &, 548 & 1 &, 615 & 1304,413 \\
\hline
\end{tabular}

Sumber : Output Spss Versi 22

\section{a. Pengaruh Audit Tenure Terhadap Opini Going Concern.}

Dari tabel 1 di atas, nilai signifikan audit tenure sebesar 0,436 lebih besar dari 0,05. Hasil tersebut dapat disimpulkan bahwa audit tenure tidak berpengaruh terhadap opini audit going concern. Hasill ini konsisten dengan penelitian Fauzan Syahputra dan M. Rizal Yahya (2017). Hal ini menunjukkan bahwa lamanya perikatan suatu KAP dengan klien tidak mempengaruhi prosesionalisme auditor untuk memberikan opini audit going concern

\section{b. Pengaruh Reputasi Auditor Terhadap Opini Going Concern.}

Dari tabel 1 di atas, nilai signifikan reputasi auditor sebesar 0,038 yang lebih kecil dari 0,05. Hasil tersebut dapat disimpulkan bahwa reputasi auditor berpengaruh terhadap opini audit going concern. Hasil ini konsisten dengan penelitian Fitria Octari Hidayanti dan Sukirman (2014). Hal ini menunjukkan bahwa tetap menjaga kepercayaan publik dan menjaga nama baik auditor sendiri 
serta KAP tempat auditor tersebut bekerja dengan mengeluarkan opini yang sesuai dengan keadaan perusahaan yang sebenarnya.

\section{c. Pengaruh Ukuran Perusahann Terhadap Opini Going Concern.}

Dari tabel di atas nilai signifikan variabel ukuran perusahaan sebesar 0,006 lebih kecil dari 0,05. Hasil tersebut dapat disimpulkan bahwa ukuran perusahaan berpengaruh terhadap opini audit going concern. Hasil ini konsisten dengan penelitian Ginting dan Linda (2014). Hal ini menunjukkan bahwa ukuran perusahaan sangant tinggi resikonya mendapat opini audit going concern, karena, semakin besar ukuran perusahaan, maka semakin meningkat pula agency cost yang terjadi, hal ini dapat terjadi karena besarnya total asset perusahaan kecenderungan diperoleh dari pinjaman jangka panjang, dimana beban bunga pinjaman tersebut dapat mempengaruhi kemampuan entitas untuk mempertahankan kelangsungan hidupnya.

\section{Pengujian Hipotesis Stimultan (Uji G)}

Uji Stimultan bertujuan untuk melihat pengaruh variabel Independent secara bersama-sama terhadap variabel dependent. Hasil Uji simultan dalam penelitian ini dapat dilihat pada tabel 2 berikut ini :

Tabel 3

Omnibus Tests of Model Coefficients

\begin{tabular}{|rl|r|r|r|}
\hline & Chi-square & Df & \multicolumn{1}{c|}{ Sig. } \\
\hline Step 1 & Step & 23,872 & 3 &, 002 \\
& Block & 23,872 & 3 &, 002 \\
& Model & 23,872 & 3 &, 002 \\
\hline
\end{tabular}

Sumber : Output Spss Versi 22

Berdasarkan tabel di atas, hasil signifikansi variabel audit tenur, reputasi auditor dan ukuran perusahaan sebesar 0,002 lebih kecil dari 0.05. Hasil tersebut dapat disimpulkan bahwa variabel audit tenur, reputasi auditor dan ukuran perusahaan secara bersama-sama berpengaruh terhadap variabel opini going concern.

\section{Analisis Regresi Logistik}

Berdasarkan Variables in The Equation Beta pada tabel 1 di atas, maka persamaan regresi logistik dari penelitian ini adalah:

$$
\mathrm{Y}=6,427-0,315 \mathrm{X}_{1}+0,594 \mathrm{X}_{2}+1,281 \mathrm{X}_{3}
$$

a. Konstanta sebesar 6,427, dapat dinotasikan jika variabel audit tenure, reputasi auditor dan ukuran perusahaan dianggap nol maka opini going concern adalah sebesar 6,427.

b. Koefisien regresi audit tenure sebesar - 0,315 yang berarti jika audit tenure mengalami kenaikan 1 satuan, sementara reputasi auditor dan ukuran perusahaan diasumsikan tetap, maka opini going concern akan mengalami penurunan sebesar - 0,315.

c. Koefisien regresi reputasi auditor sebesar 0,594 yang berarti jika reputasi auditor mengalami kenaikan 1 satauan, sementara audit tenure dan ukuran perusahaan diasumsikan tetap, maka opini going concern akan mengalami kenaikan sebesar 0,594 . 
d. Koefisien regresi ukuran perusahaan diperoleh nilai 1,281 yang berarti jika ukuran perusahaan mengalami kenaikan 1 satuan, sementara audit tenure dan reputasi auditor diasumsikan tetap, maka opini going concern akan kenaikan sebesar 1,281 .

\section{Uji Koefisien Determinasi}

\begin{tabular}{|c|c|c|c|}
\hline \multicolumn{4}{|c|}{$\begin{array}{c}\text { Tabel } 4 \\
\text { Model Summary } \\
\end{array}$} \\
\hline Step & -2 Log likelihood & $\begin{array}{l}\text { Cox \& Snell R } \\
\text { Square }\end{array}$ & $\begin{array}{l}\text { Nagelkerke R } \\
\text { Square }\end{array}$ \\
\hline 1 & $42,180^{a}$ & ,283 & ,458 \\
\hline
\end{tabular}

Tabel diatas menunjukan bahwa nilai Nagelkerke $R$ Square adalah 0,458 atau $45,80 \%$, berarti bahwa audit tenure, reputasi auditor dan ukuran perusahaan secara bersama-sama mempengaruhi opini going concern sebesar 45,80 \% sedangkan sisanya sebesar 54,20\% dipengaruhi oleh variabel lainnya yang tidak termasuk dalam penelitian ini, seperti audit delay, opini audit tahun sebelumnya, dan opinion shopping, , auditor switching, return on asset dan lain sebagainya.

\section{KETERBATASAN PENELITIAN}

1. Pada penelitian ini peneliti hanya memilih tiga variabel saja yaitu audit tenure, reputasi auditor dan pertumbujan peruhaaan. Variabel-variabel lain seperti audit delay, opini audit tahun sebelumnya, dan opinion shopping, , auditor switching, return on asset dan lain sebagainya, mungkin dapat mempengaruhi perusahaan untuk melakukan opini audit going concern tidak diuji pada penelitian ini.

2. Penelitian ini hanya terbatas pada perusahaaan manufaktur subsektor makanan dan minuman yang terdapat di Bursa Efek Indonesia, sehingga hasilnya tidak dapat digeneralisasikan untuk perusahaan- perusahaan lainnya yang terdaftar di BEI

3. Keterbatasan sampel penelitian hanya 75 sampel sehingga proses pengolahan data, analisis dan interpretasi hasil dianggap kurang, terutama dalam pengolahan data.

\section{KESIMPULAN}

1. Audit tenure tidak berpengaruh terhadap opini audit going concern. Hal ini menunjukkan bahwai lamanya perikatan suatu KAP dengan perusahaan tidak mempengaruhi prosesionalisme auditor untuk memberikan opini audit going concern

2. Reputasi auditor berpengaruh terhadap opini audit going concern. Hal ini menunjukkan bahwa tetap menjaga kepercayaan publik dan menjaga nama baik auditor sendiri serta KAP tempat auditor tersebut bekerja dengan mengeluarkan opini yang sesuai dengan keadaan perusahaan yang sebenarnya

3. Ukuran perusahaan berpengaruh terhadap opini audit going concern. Hal ini menunjukkan bahwa ukuran perusahaan sangant tinggi resikonya mendapat opini audit going concern, karena semakin besar ukuran perusahaan, maka 
semakin meningkat pula agency cost yang terjadi, hal ini dapat terjadi karena besarnya total asset perusahaan kecenderungan diperoleh dari pinjaman jangka panjang, dimana beban bunga pinjaman tersebut dapat mempengaruhi kemampuan entitas untuk mempertahankan kelangsungan hidupnya

4. Hasil penelitian menunjukan bahwa audit tenur, reputasi auditor dan ukuran secara bersama-sama mempengaruhi opini going concern, sebesar 45,80\% sedangkan sisanya sebesar 54,20\% dipengaruhi oleh variabel lainnya yang tidak termasuk penelitian ini seperti likuiditas, debt default, auditor switching, return on asset dan variabel lainnya.

\section{SARAN}

1. Penelitian lebih lanjut disarankan untuk menambahkan variabel-variabel lain diluar variabel yang telah digunakan dalam penelitian ini, seperti audit delay, opini audit tahun sebelumnya, dan opinion shopping, auditor switching, return on asset dan lain sebagainya.

2. Penelitian lebih lanjut diharapkan dapat memperluas tahun pengamatan atau objek penelitian, sehingga hasil penelitian lebih mungkin untuk disimpulkan dalam vakupan yang lebih luas.

3. Hendaknya penelitian selanjutnya lebih mempersiapkan waktu dalam melakukan penelitian empiris guna lebih meningkat perolehan data penelitian.

\section{DAFTAR PUSTAKA}

\section{Buku (Text Book)}

Agoes, Sukrisno. (2014). Auditing Petunjuk Praktis Pemeriksaan Akuntan oleh Akuntan Publik. Edisi ke 4. Buku 1. Jakarta : Salemba Empat

Arens A. Alvin, Randal J. Elder dan Mark S. Beasley. 2015. Auditing dan Jasa Assurance Pendekatan Terintegrasi. Jilid 1. Edisi Lima Belas-Jakarta. Erlangga.

Ghozali, I. (2016). Aplikasi Analisis Multivariet Dengan Program IBM SPSS 23. Edisi 8. Semarang: Penerbit Badan Penerbit Universitas Diponogoro.

Hery. (2017). Kajian Riset Akuntansi. Jakarta. Grasindo.

Mulyadi. 2010. “Auditing”.Edisi Ke-6. Salemba Empat, Jakarta.

SPAP. (2016). Standar Audit 700 Perumusan Suatu Opini Pelaporan Atas Laporan Keuangan.IAPI.

Sugiyono. (2017). Metode Penelitian Kuantitatif, Kualitatif, dan R\&D. Bandung: Alfabeta, CV.

Tuanakotta, Theodorus M. (2011). Berpikir Kritis Dalam Auditing. Salemba Empat, Jakarta.

William F. Messier et al. 2014. Jasa Audit dan Assurance Pendekatan Sistematis. Jakarta: Salemba Empat

\section{Jurnal (Journal)}

Anindya Sekar Ayu Miraningtyas dan Yudowati, S, 2019, Pengaruh Likuiditas, Reputasi Auditor Dan Disclosure Terhadap Pemberian Opini Audit Going Concern, Jurnal Ilmiah Manajemen Ekonomi \& Akuntansi, Vol 
3 No 3, STIEM, Bandung

Al-Thuneibat, A., Al Issa, R., \&Baker, R. (2011). Do Audit Tenure and Firm Size Contribute to Audit Quality .Managerial Auditing Journal, Vol. 26 No. 4, pp. 317-334.

Azizah, Rizki. dan Indah Anisykurlillah. (2014). Pengaruh Ukuran Perusahaan, Debt Default, dan Kondisi Keuangan Perusahaan Terhadap Penerimaan Opini Audit Going Concern (Pada Perusahaan Manufaktur yang Terdaftar di Bursa Efek Indonesia pada Tahun 2010-2013). Accounting Analysis Journal. Universitas Negeri Semarang

Bonita, R., P. (2017). Pengaruh profitabilitas, likuiditas, solvabilitas dan pertumbuhan perusahaan terhadap opini audit going concern. Universitas Islam Negeri Syarif Hidayatullah.

Fauzan Syahputra dan M. Rizal Yahya, 2017, Pengaruh Audit Tenure, Audit Delay, Opini Audit Tahun Sebelumnya Dan Opinion Shopping Terhadap Penerimaan Opini Audit Going Concern Pada Perusahaan Manufaktur Yang Terdaftar Di Bursa Efek Indonesia Tahun 20132015, Jurnal Ilmiah Mahasiswa Ekonomi Akuntansi (JIMEKA) Vol. 2, No. 3, (2017) Halaman 39-47

Fitria Octari Hidayanti dan Sukirman, 2014, Reutasi Auditor, Ukuran Perusahaan dan Opini Audit Tahun Sebelumnya Dalam Memprediksi Pemberian Opini Audit Going Concern, Accounting Analysis Journal, Volume No 4, Jurusan Akuntansi, Fakultas Ekonomi, Universitas Negeri Semarang

Ginting, Suriani dan Linda Suryana. (2014). Analisis Faktor-Faktor yang Mempengaruhi Opini Audit Going Concern pada Perusahaan Manufaktur di BEI. Jurnal Ekonomi Mikroskis. Vol. 4, No. 2, Hal 111-120.

Krissindiastuti, M. dan Ni Ketut Rasmini. (2016). Faktor-Faktor yang Mempengaruhi Opini Audit Going Concern. E-Jurnal Akuntansi Universitas Udayana, 14(1): h:451-481

Komang Anggita Verdiana dan I Made Karya Utama, 2013, Pengaruh Reputasi Auditor, Disclosure, Audit Client Tenure Pada Kemungkinan Pengungkapan Opini Audit Going Concern, Jurnal Akuntansi, Vol 5, No. 3, Universitas Udayana

Menteri Keungan. (2018). Peraturan Menteri Keuangan Republik Indonesia nomor 17/PMK.01/2008 tentang Kantor Akuntan Publik. Jakarta.

M. Nur Fahmi, 2015, Pengaruh Audit Tenure, Audit Delay, Opini Audit Tahun Sebelumnya Dan Opinion Shopping Terhadap Penerimaan Opini Audit Going Concern Pada Perusahaan Manufaktur Yang Terdaftar Di Bursa Efek Indonesia Tahun 2013-2015, Jurnal Ilmiah Mahasiswa Ekonomi Akuntansi (JIMEKA) Vol. 2, No. 3, Halaman 39-47

Ni Made Puspa Pawitri dan Ketut Yadnyana, 2015, Pengaruh Audit Delay, Opini Audit, Reputasi Auditor Dan Pergantian Manajemen Pada Voluntary Auditor Switching, E Jurnal Akuntansi, Vol 10 No. 1, Universitas Udayana

Putrid, Tria Widiastuti, M.Rasuli, dan Volta Diyanto. 2014. "Pengaruh Opinion Shopping, Reputasi Auditor, Disclosure, dan Ukuran Perusahaan Terhadap Penerimaan Opini Audit Going Concern pada Perusahaan 
Manufaktur 2011-2013 yang Lising di Bursa Efek Indonesia”. Jurnal Akuntansi:Universitas Riau Vol.1 No.2

Republik Indoneia. 2015. Peraturan Pemerintah No. 20 Tahun 2015 Tentang Praktik Akuntan Publik. Sekretariat Negara. Jakarta

Rizki Azizah dan Indah Anisykurlillah, 2014, Pengaruh Ukuran Perusahaan. Debt Default, dan Kondisi Perusahaan Terhadap Penerimaaan Opini Audit Going concern,Accounting Analysis Journal, Vol 3, Nomor 4, Jurusan Akuntansi, Fakultas Ekonomi, Universitas Negeri Semarang,

Seftianne dan Handayani. 2011. Faktor - Faktor yang Mempengaruhi Struktur Modal pada Perusahaan Publik Sektor Manufaktur. Jurnal Bisnis dan Akuntansi, Volume 13, No. 1, April 2011, Halaman 39 - 56.

.Wulandari, S. (2014). Analisis Faktor-Faktor yang Mempengaruhi Auditor Dalam Memberikan Opini Audit Going Concern. E-Jurnal Akuntansi Universitas Udayana. 


\title{
PENGARUH UKURAN PERUSAHAAN, PROFITABILITAS, LEVERAGE, DAN KUALITAS AUDIT TERHADAP PENGHINDARAN PAJAK PADA PERUSAHAAN MANUFAKTUR PERIODE 2016-2018
}

\author{
Tagor Darius Sidauruk, SE., M.Si \\ Siti Nur Fadilah \\ tagor.darius@yahoo.com
}

\section{Fakultas Ekonomi dan Bisnis - Program Studi Akuntansi Universitas Satya Negara Indonesia}

\begin{abstract}
ABSTRAK
Perusahaan berusaha menekan biaya pajaknya demi mendapatkan laba yang lebih tinggi. Terdapat beberapa faktor yang mempengaruhi penghindaran pajak dalam suatu perusahaan. Penelitian ini bertujuan untuk mengetahui apakah ukuran perusahaan, profitabilitas, leverage, dan kualitas audit berpengaruh terhadap penghindaran pajak.

Populasi penelitian ini adalah perusahaan manufaktur yang terdaftar di Bursa Efek Indonesia (BEI) pada tahun 2016-2018 yaitu sebanyak 153 perusahaan. Sampel penelitian berjumlah 72 perusahaan atau 216 data observasi yang dipilih dengan metode purposive sampling. Data yang dipergunakan adalah data sekunder yang diperoleh dari Bursa Efek Indonesia (BEI). Metode analisis data dalam penelitian ini yaitu Analisis Statistik Deskriptif, analisis Regresi Logistik.

Hasil penelitian menunjukkan bahwa ukuran perusahaan, leverage, dan kualitas audit tidak berpengaruh terhadap penghindaran pajak. Sedangkan profitabilitas berpengaruh positif terhadap penghindaran pajak.
\end{abstract}

Kata Kunci: Ukuran Perusahaan, Profitabilitas, Leverage, Kualitas Audit, dan Penghindaran Pajak 


\section{PENDAHULUAN}

\section{Latar Belakang}

Sektor pajak merupakan salah satu penerimaan negara yang berkontribusi paling besar dalam menunjang pembangunan dan pembiayaan nasional serta mewujudkan kemandirian suatu negara. Pemerintah pastinya menginginkan penerimaan dari sektor pajak yang selalu meningkat tiap tahunnya. Usaha pemerintah untuk mengoptimalkan penerimaan sektor pajak dilakukan melalui usaha intensifikasi dan ekstensifikasi penerimaan pajak.

Perusahaan merupakan salah satu wajib pajak yang memberikan kontribusi terbesar dalam penerimaan pajak suatu negara, namun ternyata banyak perusahaan yang menganggap bahwa pajak merupakan komponen beban dalam laporan keuangan yang dapat mengurangi laba bersih mereka. Masih banyaknya wajib pajak dalam hal ini perusahaan yang berusaha untuk membayar pajak serendah mungkin dengan cara melakukan perencanaan pajak sehingga mengakibatkan menurunnya penerimaan negara dari pajak tersebut. Menurut, Suandy (2013) mengatakan bahwa pada umumnya para pelaku usaha (perusahaan) mengidentikkan pembayaran pajak sebagai beban yang akan menurunkan laba setelah pajak, tingkat pengembalian, dan arus kas.

Penghindaran pajak merupakan usaha mengurangi hutang yang bersifat legal sedangkan penggelapan pajak (Tax evasion) adalah usaha untuk mengurangi hutang pajak yang bersifat tidak legal. penghindaran pajak merupakan hal yang tidak diinginkan bagi pemerintah namun disisi lain tindakan tersebut tergolong dalam tindakan legal dan tidak melanggar hukum karena metode dan teknik yang digunakan adalah dengan memanfaatkan kelemahan (grey area) yang terdapat dalam undang-undang dan peraturan perpajakan itu sendiri, sehingga dalam hal ini Direktorat Jenderal Pajak tidak dapat melakukan penuntutan secara hukum kepada para pelaku tindakan penghindaran pajak. jumlah kasus tindakan tax avoidance yang terjadi di Indonesia masih cukup banyak sehingga hal tersebut berdampak pada berkurangnya penerimaan pajak. Fenomena kasus penghindaran pajak pada tahun 2014 Direktorat jenderal Pajak telah menyelidiki kasus penghindaran pajak oleh PT. Coca Cola Indonesia (CCI) diduga mengakali pajak sehingga menimbulkan kekurangan pembayaran pajak senilai Rp. 49,24 miliar.

Ukuran perusahaan sebagai skala atau nilai yang dapat mengklasifikasikan suatu perusahaan ke dalam kategori besar atau kecil berdasarkan total aset. Tahap kedewasaan perusahaan ditentukan berdasarkan total aset, semakin besar total aset menunjukkan bahwa perusahaan memiliki prospek baik dalam jangka waktu yang relatif panjang. Dengan besarnya total aset perusahaan tentunya akan cenderung mendorong perusahaan untuk melakukan praktik penghindaran pajak (Deddy, 2016). Namun perusahaan besar yang sudah go public tentunya akan melihat dari sisi publik apabila perusahaan melakukan praktik penghindaran pajak dan diketahui oleh fiskus tentunya ini akan membuat citra buruk perusahaan dimata publik dan mengurangi rasa percaya publik atas perusahaan tersebut. Ida Ayu Rosa Dewinta dan Putu Ery Setiawan (2016) dalam penelitiannya membuktikan bahwa ukuran perusahaan berpengaruh terhadap penghindaran pajak. Sementara penelitian Annisa (2017) menyatakan bahwa ukuran perusahaan tidak berpengaruh signifikan terhadap penghindaran pajak.

Jurnal Ilmiah Akuntansi dan Ekonomi Volume. 5 Nomor. 2, Agustus 2020 Hal. 87 
Profitabilitas merupakan gambaran kinerja keuangan perusahaan dalam menghasilkan laba dari pengelolaan aset yang dikenal dengan Return On Assets (ROA). Profitabilitas yang tinggi menunjukkan bahwa perusahaan mampu mendapatkan laba yang maksimal. Semakin tinggi laba perusahaan maka semakin tinggi beban pajaknya. Dalam penelitian yang dilakukan oleh Ida Ayu Rosa Dewinta dan Putu Ery Setiawan (2016) menemukan bahwa profitabilitas berpengaruh secara negatif terhadap penghindaran pajak. Sedangkan menurut Deddy Dyas Cahyono (2016) menemukan bahwa profitabilitas tidak berpengaruh terhadap penghindaran pajak.

Leverage merupakan rasio yang mengukur seberapa besar perusahaan dibiayai dengan hutang. Suatu perusahaan yang memiliki tingkat leverage yang tinggi menunjukkan perusahaan tersebut bergantung pada hutang. Dengan adanya hutang akan menimbulkan beban tetap yaitu bunga, semakin perusahaan bergantung pada hutang maka beban hutang yang dibayarkan juga semakin besar. Beban hutang yang semakin tinggi akan memberikan pengaruh berkurangnya jumlah beban pajak perusahaan. Hasil penelitian Deddy Dyas Cahyono (2016) menunjukkan bahwa leverage tidak memiliki pengaruh yang signifikan terhadap penghindaran pajak. Sedangkan Annisa (2017) mengungkapkan bahwa leverage berpengaruh positif terhadap tax avoidance.

Kualitas audit adalah terjadinya segala kemungkinan saat auditor mengaudit laporan keuangan klien dan menemukan pelanggan atau kesalahan yang terjadi dan melaporkannya dalam laporan keuangan. Laporan keuangan yang diaudit oleh KAP The Big Four lebih berkualitas sehingga menampilkan nilai perusahaan yang sebenarnya, oleh karena itu diduga perusahaan yang diaudit oleh KAP The Big Four memiliki tingkat kecurangan pajak yang lebih rendah dibandingkan oleh perusahaan yang diaudit oleh KAP Non The Big Four. Jika nominal pajak yang dibayar terlalu tinggi biasanya akan memaksa perusahaan untuk melakukan penggelapan pajak, maka semakin berkualitas audit suatu perusahaan, maka perusahaan tersebut cenderung tidak melakukan manipulasi laba untuk kepentingan perpajakan. Arry Eksandy (2017) mengatakan bahwa kualitas audit berpengaruh positif terhadap penghindaran pajak. Sedangkan Fitri Darmayanti dan Tridahus Susanto (2015) mengatakan bahwa kualitas audit tidak berpengaruh terhadap penghindaran pajak.

Berdasarkan uraian di atas, peneliti bermaksud untuk melakukan penelitian yang berjudul: "Pengaruh Ukuran Perusahaan, Profitabilitas, Leverage, dan Kualitas Audit Terhadap Penghindaran Pajak pada perusahaan Manufaktur periode 2016-2018”.

\section{Rumusan Masalah}

Berdasarkan latar belakang di atas, maka perumusan masalah dalam penelitian ini adalah sebagai berikut :

1. Apakah ukuran perusahaan berpengaruh terhadap penghindaran pajak?

2. Apakah profitabilitas berpengaruh terhadap penghindaran pajak?

3. Apakah leverage berpengaruh terhadap penghindaran pajak?

4. Apakah kualitas audit berpengaruh terhadap penghindaran pajak?

\section{Tujuan Penelitian}

1. Untuk mengetahui pengaruh ukuran perusahaan terhadap penghindaran pajak. 
2. Untuk mengetahui pengaruh Profitabilitas terhadap penghindaran pajak.

3. Untuk mengetahui pengaruh Leverage terhadap penghindaran pajak.

4. Untuk mengetahui kualitas audit terhadap penghindaran pajak.

\section{LANDASAN TEORI}

\section{Penghindaran Pajak}

Menurut Undang-Undang Nomor 16 Tahun 2009 tentang Ketentuan Umum Perpajakan, pajak adalah kontribusi wajib kepada negara yang terutang oleh orang pribadi ataupun badan yang bersifat memaksa berdasarkan undang-undang dengan tidak mendapatkan imbalan secara langsung dan digunakan untuk keperluan negara bagi sebesar-besarnya kemakmuran rakyat.

Menurut Pohan (2013) manajemen pajak adalah usaha yang dilakukan tax manager agar hal-hal yang berhubungan dengan perpajakan dapat dikelola dengan baik, efisien dan ekonomis, sehingga memberi kontribusi maksimal bagi perusahaan. Fungsi-fungsi manajemen pajak adalah perencanaan pajak (tax planning), pelaksanaan kewajiban perpajakan (tax implementation), pengendalian pajak (tax control). Perencanaan pajak merupakan bagian dari manajemen perpajakan serta tahap awal untuk melakukan analisis secara sistematis berbagai alternatif perlakuan perpajakan dengan tujuan untuk mencapai pemenuhan kewajiban perpajakan minimum. Menurut Pohan (2013) strategi yang dapat ditempuh untuk mengefisiensikan beban pajak secara legal yaitu: (a) Penghematan pajak, (b) Penghindaran pajak atau tax avoidance, (c) Mengoptimalkan kredit pajak yang diperkenankan, (d) Menghindari pemeriksaan pajak dengan cara menghindari lebih bayar, dan (e) Menghindari pelanggaran pajak terhadap peraturan yang berlaku.

Menurut Mohammad Zain (2007) penghindaran pajak (Tax avoidance) adalah suatu tindakan yang benar-benar legal agar terhindar dari konsekuensi pengenaan pajak yang tidak dikehendaki, dalam hal ini sama sekali tidak ada suatu pelanggaran hukum dalam ketentuan peraturan perundang-undangan perpajakan yang dilakukan dan malah akan diperoleh penghematan pajak sehingga terhindar dari pengenaan pajak yang lebih besar atau mungkin sama sekali tidak kena pajak. Menurut Pohan (2013) penghindaran pajak merupakan hal yang tidak diinginkan bagi pemerintah namun disisi lain tindakan tersebut tergolong dalam tindakan secara legal, aman bagi wajib pajak dan tidak melanggar hukum, di mana metode dan teknik yang digunakan cenderung dengan memanfaatkan kelemahan (grey area) yang terdapat dalam undang-undang dan peraturan perpajakan itu sendiri untuk memperkecil jumlah pajak yang terutang. Penghindaran pajak bukannya bebas biaya. Beberapa biaya yang harus ditanggung yaitu pengorbanan waktu dan tenaga untuk melakukan penghindaran pajak, dan adanya risiko jika penghindaran pajak terungkap. Risiko tersebut adalah bunga dan denda; dan kehilangan reputasi perusahaan yang berakibat buruk untuk keberlangsungan usaha jangka panjang perusahaan.

Penghindaran pajak dapat diukur dengan menggunakan Cash Effective Tax Ratio (CETR). Cash Effective Tax Rate (CETR) yaitu kas yang dikeluarkan untuk pembayaran pajak dibagi dengan laba sebelum pajak. Perusahaan dikategorikan melakukan penghindaran pajak apabila Cash Effective Tax Rate (CETR) kurang 
dari $25 \%$ dan dikategorikan tidak melakukan penghindaran pajak apabila Cash Effective Tax Rate (CETR) lebih dari 25\% atau mendekati tarif pajak.

\section{Ukuran Perusahaan}

Menurut (Jogiyanto, 2013) ukuran perusahaan adalah besar kecilnya perusahaan yang dapat diukur dengan nilai total aset atau besar harta perusahaan dengan menggunakan perhitungan nilai natural log (Ln) total aset. Menurut Agnes Sawir (2012) ukuran perusahaan adalah ukuran yang dapat menentukan tingkat kemudahan perusahaan memperoleh dana dari pasar modal. Menurut Hormati (2009) dalam Yudi Mufti Prawira (2016) ukuran perusahaan adalah skala atau nilai yang dapat menunjukkan suatu perusahaan ke dalam kategori besar atau kecil berdasarkan total aset, log size, dan sebagainya.

Ukuran perusahaan adalah suatu skala yang dapat mengklasifikasikan perusahaan menjadi perusahaan besar dan kecil menurut berbagai cara seperti total aktiva atau total asset perusahaan, nilai pasar saham, rata-rata tingkat penjualan, dan jumlah penjualan. Perusahaan yang tergolong besar akan memiliki sumber daya yang besar salah satunya sumber daya manusia yang ahli dibidang perpajakan. Maka dari itu perusahaan besar cenderung melakukan praktik penghindaran pajak karena perusahaan besar memiliki sumber daya manusia yang ahli sangat dibutuhkan guna menekan beban pajak yang harus dibayarkan perusahaan (Yudi Mufti Prawira, 2016).

Ukuran perusahaan bisa diukur dengan menggunakan total aset, pendapatan atau modal dari perusahaan tersebut. Salah satu tolak ukur yang menunjukkan besar kecilnya perusahaan adalah ukuran aktiva dari perusahaan tersebut. Perusahaan yang memiliki total aset besar menunjukkan bahwa perusahaan tersebut telah mencapai tahap kedewasaan, dimana dalam tahap ini arus kas perusahaan sudah positif dan dianggap memiliki prospek yang baik dalam jangka waktu yang relatif stabil dan lebih mampu menghasilkan laba dibandingkan perusahaan dengan total aset yang kecil.

Menurut (Jogiyanto, 2013) pengukuran ukuran perusahaan dapat dihitung dengan rumus sebagai yaitu: Ukuran Perusahaan = Ln (Total Aset). Ln (total aset) dinilai lebih baik karena ukuran perusahaan ini memiliki tingkat kestabilan yang lebih. Tujuan pengguna Ln (Total Aset) untuk mengurangi fluktuasi data yang berlebih. Dengan menggunakan rasio ini, nilai miliar bahkan triliun akan disederhanakan, tanpa mengubah proporsi dan nilai aset sebenarnya.

\section{Profitabilitas}

Menurut Agus Sartono (2012) menyatakan bahwa profitabilitas adalah kemampuan memperoleh laba yang maksimal selama periode tertentu dalam hubungannya dengan penjualan, total aktiva maupun modal sendiri perusahaan tersebut. Tujuam akhir yang ingin dicapai suatu perusahaan adalah memperoleh laba yang maksimal. Manajemen perusahaan dituntut harus mampu untuk memenuhi target yang telah ditetapkan. Rasio profitabilitas merupakan rasio untuk menilai kemampuan perusahaan dalam mencari laba. Hasil pengukuran tersebut dapat dijadikan alat evaluasi kinerja manajemen selama ini.

Tujuan penggunaan rasio profitabilitas adalah: (1) untuk mengukur laba yang diperoleh perusahaan dalam satu periode tertentu. (2) menilai posisi laba perusahaan tahun sebelumnya dengan tahun sekarang. (3) menilai perkembangan 
laba dari waktu ke waktu. (4) menilai besarnya laba bersih sesudah pajak dengan modal sendiri. (5) mengukur produktivitas dari seluruh dana perusahaan yang digunakan baik modal pinjaman maupun modal sendiri.

Menurut Undang-Undang No. 36 Tahun 2008 pasal 1 dijelaskan bahwa penghasilan yang diterima oleh subjek pajak akan dikenakan pajak penghasilan. Besar kecilnya pajak yang harus dibayarkan wajib pajak berbanding lurus dengan besar kecilnya penghasilan yang diperoleh wajib pajak dalam satu periode, sehingga semakin tinggi profitabilitas perusahaan maka semakin tinggi pajak yang harus dibayarkan sedangkan perusahaan yang memiliki tingkat keuntungan yang rendah atau bahkan mengalami rugi akan membayar pajak lebih sedikit atau tidak sama sekali.

Menurut Kasmir (2014) terdapat empat jenis utama yang digunakan dalam menilai tingkat profitabilitas, yaitu: (1) Gross Profit Margin/ Margin Laba Kotor, (2) Net Profit Margin/ Margin Laba Bersih), (3 Return On Equity, dan (4) Return On Asset. Margin Laba Kotor Merupakan rasio yang mengukur efisiensi operasi perusahaan dan juga pengendalian harga pokok penjualan. Semakin besar margin laba kotor semakin baik keadaan operasi perusahaan, karena hal ini menunjukkan bahwa harga pokok penjualan relatif rendah dibandingkan dengan penjualan. Margin laba bersih Merupakan rasio yang mengukur penjualan yang sudah dikurangi dengan seluruh biaya dan pengeluaran, termasuk bunga dan pajak.

Return On Equity Merupakan rasio yang mengukur sejauh mana kemampuan perusahaan memperoleh laba bersih setelah pajak dengan modal sendiri. Rasio ini mengukur tingkat keuntungan dari investasi yang telah dilakukan pemilik perusahaan. ROA merupakan rasio yang menunjukkan hasil atas jumlah aset yang digunakan dalam perusahaan. ROA juga merupakan suatu ukuran tentang efektivitas manajemen dalam mengelola investasinya. Semakin kecil rasio ini semakin kurang baik, dan sebaliknya.

\section{Leverage}

Menurut Kasmir (2014) leverage adalah rasio yang digunakan untuk mengukur sejauh mana perusahaan dibiayai dengan hutang. Artinya, berapa besar hutang yang ditanggung perusahaan dibandingkan dengan asetnya. Menurut Agus Sartono (2012) leverage adalah penggunaan aset dan sumber dana oleh perusahaan yang memiliki beban tetap dengan maksud agar meningkatkan keuntungan potensial pemegang saham. Perusahaan yang mempunyai leverage yang tinggi menunjukkan perusahaan tersebut banyak bergantung pada hutang dalam membiayai aset perusahaan. Hutang akan menyebabkan adanya beban bunga atas pinjaman tersebut yang dapat mengurangi penghasilan kena pajak perusahaan.

Tujuan perusahaan menggunakan rasio leverage menurut Kasmir (2014), diantaranya yaitu: (a) Perusahaan mengetahui posisi perusahaan terhadap kewajiban kepada pihak lainnya. (b) Untuk menilai kemampuan perusahaan dalam memenuhi kewajiban yang bersifat tetap (seperti angsuran pinjaman termasuk bunga). (c) Untuk menilai keseimbangan antara nilai aktiva khususnya aktiva tetap dan modal. (d) Untuk menilai seberapa besar aktiva perusahaan dibiayai oleh hutang. (e) Untuk menilai seberapa besar pengaruh hutang perusahaan terhadap pengelolaan aktiva. (f) Untuk menilai atau mengukur berapa bagian dari setiap rupiah modal sendiri yang dijadikan jaminan hutang jangka panjang. (g) Untuk menilai berapa dana 
pinjaman yang segera akan ditagih, terdapat sekian kalinya modal sendiri yang dimiliki.

Menurut Kasmir (2014) rasio leverage secara umum adalah: (1) Debt to Total Asset Ratio/ DAR, (2) Debt to Equity Ratio/ DER, (3) Time Interest Earned/ TIE, (4) Fixed Charge Coverage Ratio, dan (5) Long-term Debt to Equity Ratio. DAR Merupakan rasio yang digunakan untuk mengukur perbandingan antara total hutang dengan total aktiva. Rasio DAR merupakan rasio yang digunakan untuk mengukur seberapa besar beban hutang yang harus ditanggung perusahaan dalam rangka pemenuhan aset, perusahaan dalam operasinya menggunakan sumber dana yang menimbulkan beban tetap bagi perusahaan.

DER merupakan rasio yang digunakan untuk menilai utang dengan ekuitas. Rasio ini dihitung dengan cara membandingkan antara seluruh utang terhadap seluruh ekuitas. Rasio ini berguna untuk mengetahui jumlah dana yang disediakan kreditor dengan pemilik perusahaan. Rasio ini berfungsi untuk mengetahui setiap rupiah modal sendiri yang dijadikan untuk jaminan utang. Bagi kreditur, semakin tinggi rasio ini maka akan semakin tidak menguntungkan karena akan semakin besar risiko yang ditanggung atas kegagalan yang mungkin terjadi di perusahaan. Namun, bagi perusahaan semakin besar rasio ini akan semakin baik. Sebaliknya, dengan rasio yang rendah, semakin tinggi tingkat pendanaan yang disediakan pemilik dan semakin besar batas pengamanan bagi peminjam jika terjadi kerugian atau penyusutan terhadap nilai aktiva. Perusahaan dengan arus kas yang stabil biasanya memiliki rasio yang lebih tinggi dari rasio kas yang kurang stabil. TIE Merupakan rasio yang digunakan untuk mengukur kemampuan perusahaan untuk membayar bunga, atau mengukur seberapa jauh pendapatan dapat berkurang tanpa perusahaan mengalami kesulitan keuangan karena tidak mampu membayar bunga. Rasio FCC mengukur seberapa besar kemampuan perusahaan untuk menutup beban tetapnya termasuk pembayaran deviden saham preferen, bunga, angsuran pinjaman dan sewa.

\section{Kualitas Audit}

Kualias audit dapat diukur berdasarkan ukuran Kantor Akuntan Publik (KAP) yang mengaudit laporan keuangan perusahaan (Mathius Tandiontong, 2015). Kualitas audit merupakan segala kemungkinan dimana auditor pada saat mengaudit laporan keuangan klien atau perusahaan dapat menemukan pelanggaran yang terjadi dalam sistem akuntansi klien dan melaporkannya dalam laporan keuangan auditan, dimana dalam melaksanakan tugasnya tersebut auditor mengikuti pedoman pada standar auditing dan kode etik akuntan publik yang relevan.

Laporan keuangan yang diaudit oleh auditor KAP The Big Four menurut beberapa referensi lebih berkualitas karena lebih mampu membatasi praktik manajemen laba sehingga menampilkan nilai perusahaan yang sebenarnya, oleh karena itu diduga perusahaan yang diaudit oleh KAP The Big Four memiliki tingkat kecurangan yang lebih rendah dibandingkan dengan perusahaan yang diaudit KAP Non The Big Four (Nuralifmida Ayu Annisa dan Lulus Kurniasih 2012 dalam Fitri dan Tridahus, 2015). 


\section{METODOLOGI PENELITIAN}

\section{Waktu dan Tempat Penelitian}

Penelitian ini dilakukan selama 4 bulan yaitu dimulai bulan April sampai dengan Juli 2020. Penelitian ini dilakukan pada Bursa Efek Indonesia (BEI) yang beralamat di Menara I Jl. Sudirman Kav 52 -53 Jakarta Selatan 12190 Indonesia, dengan melalui website BEI yaitu www.idx.co.id

\section{Desain Penelitian}

Desain penelitian yang digunakan adalah penelitian kausal (causal research) yang merupakan penelitian untuk mengetahui pengaruh antara satu atau lebih variabel bebas terhadap variabel terikat.

\section{Variabel Penelitian}

Variabel yang digunakan dalam penelitian ini adalah sebagai berikut:

a. Variabel bebas atau independen yaitu ukuran perusahaan (X1), Profitabilitas (X2), Leverage (X3), dan kualitas audit (X4). Ukuran perusahaan diproksikan dengan Ln total aset. Profitabilitas diproksikan dengan ROA. ROA merupakan rasio yang menunjukkan seberapa besar kontribusi aset dalam menciptakan laba bersih. ROA dihitung dengan cara membagi laba bersih setelah dengan total aset. Leverage diproksikan DAR. Rasio DAR yang digunakan untuk mengukur perbandingan antara total hutang dengan total aktiva. Kualitas audit dapat diukur melalui Kantor Akuntan Publik (KAP) yang mengaudit laporan keuangan perusahaan. KAP yang berafiliasi dengan KAP The Big Four dan yang tidak berafiliasi dengan KAP The Big Four.

b. Variabel terikat atau dependen yaitu penghindaran pajak, yang diproksikan dengan CETR. CETR merupakan perbandingan antara pembayaran pajak dengan laba sebelum pajak.

\section{Jenis dan Sumber Data}

Penelitian ini menggunakan data sekunder, yaitu data yang diperoleh dari pihak lain atau data yang telah tersedia. Data tersebut (laporan keuangan) diperoleh dari website Bursa Efek Indonesia (www.idx.co.id).

\section{Populasi dan Sampel}

Dalam penelitian ini populasi yang digunakan yaitu perusahaan manufaktur yang terdaftar di Bursa Efek Indonesia periode 2016 - 2018, dan sampel dalam penelitian ini menggunakan metode Purposive Sampling. Adapun kriteria yang digunakan dalam penelitian ini adalah sebagai berikut : (1) Perusahaan manufaktur yang terdaftar di BEI pada periode tahun 2016 sampai dengan tahun 2018. (2) Perusahaan yang menyajikan data keuangan yang lengkap selama periode tahun 2016 sampai dengan tahun 2018. (3) Perusahaan yang menyajikan laporan keuangan tahunan yang dinyatakan rupiah. (4) Perusahaan yang memperoleh laba selama periode penelitian yaitu tahun 2015 sampai dengan tahun 2017 .

\section{Metode Analisis Data Statistik Deskriptif}


Statistik deskriptif yaitu suatu teknik analisis data yang berusaha menjelaskan atau menggambarkan berbagai karakteristik data. Program yang digunakan untuk mengolah data adalah Statistical Product and Service Solution versi 22.00 .

\section{Analisis Regresi Logistik}

Pada penelitian ini menggunakan analisis regresi logistik (logistic regression). Regresi logistik digunakan apabila variabel dependennya adalah satu metrik dan variabel independennya lebih dari satu metrik dan non metrik. Pada teknik analisis regresi logitik tidak memerlukan lagi uji normalitas dan uji asumsi klasik pada variabel bebasnya.

Adapun model regresi logistic yang terbentuk adalah:

Keterangan:

$\mathrm{Y}=\beta 1 \mathrm{X} 1+\beta 2 \mathrm{X} 2+\beta 3 \mathrm{X} 3+\beta 4 \mathrm{X} 4+\varepsilon$

$$
\begin{array}{ll}
\mathrm{Y} & =\text { Penghindaran pajak } \\
\alpha & =\text { Konstanta } \\
\beta 1-\beta 4 & =\text { Koefisien regresi variabel independen } \\
\mathrm{X} 1 & =\text { Ukuran perusahaan } \\
\mathrm{X} 2 & =\text { Profitabilitas } \\
\mathrm{X} 3 & =\text { Leverage } \\
\mathrm{X} 4 & =\text { Kualitas audit } \\
\varepsilon & =\text { Error }
\end{array}
$$

Langkah-langkah dalam pengujian regresi logistic adalah sebagai berikut:

a. Menilai Keseluruhan Model (Overall Model Fit)

Langkah pertama adalah menilai Overall fit model terhadap data. Hipotesis untuk menilai model fit adalah sebagai berikut: (1) H0: Model yang dihipotesiskan fit dengan data, dan (2) HA: Model yang dihipotesiskan tidak fit dengan data. Hipotesis yang digunakan untuk menilai overall fit model adalah sebagai berikut: (a) Jika nilai -2 log Likelihood ada penurunan, maka H0 diterima, yang berarti bahwa model fit dengan data. (b) Jika nilai -2 log Likelihood tidak ada penurunan, maka H0 ditolak, yang berarti bahwa model tidak fit dengan data.

b. Koefisien Determinasi (Negelkerke R square)

Koefisiensi determinasi digunakan untuk mengetahui seberapa jauh kemampuan model variabel independen (ukuran perusahaan, profitabilitas, leverage, dan kualitas audit) dalam menerangkan variasi variabel dependen (penghindaran pajak).

c. Menilai Kelayakan Model Regresi

Kelayakan model regresi dapat diuji dengan Hosmer and Lemeshow's Goodness of Fit Test. Model ini bertujuan untuk menguji hipotesis bahwa data empirik cocok atau sesuai dengan model. Hipotesis yang digunakan untuk menilai kelayakan model regresi adalah sebagai berikut: jika nilai Statistics Hosmer and Lemesho Goodness of Fit $<0,05$ maka H0 ditolak, yang berarti bahwa model tidak dapat memprediksi nilai observasinya, dan sebaliknya.

d. Matriks Klasifikasi 
Matriks klasifikasi bertujuan untuk melihat presentasi estimasi perusahaan yang melakukan penghindaran pajak dan perusahaan tidak melakukan penghindaran pajak.

e. Omnibus Test

Pengujian pengaruh model secara simultan dalam penelitian ini menggunakan tabel Omnibus Tests of Model Coefficients. Uji ini mirip dengan uji F pada analisis regresi linier berganda.

Nilai uji ini dapat dilihat menggunakan $p$-value kemudian dibandingkan dengan nilai $\alpha$, dengan kriteria pengambilan keputusan sebagai berikut: (1) Jika $p$-value $>\alpha(0,05)$ maka variabel-variabel independen tidak berpengaruh secara simultan terhadap variabel dependen atau H0 diterima. Dan sebaliknya, (2) Jika $p$-value $<\alpha(0,05)$ maka variabel-variabel independen berpengaruh secara simultan terhadap variabel dependen atau H0 ditolak.

f. Pengujian Hipotesis Penelitian

Hipotesis dalam penelitian ini adalah untuk mengetahui pengaruh ukuran perusahaan, profitabilitas, leverage, dan kualitas audit terhadap penghindaran pajak.

Penentuan diterim atau tidaknya Ho didasarkan pada tingkat signifikan $\alpha=5 \%$ dengan kriteria sebagai berikut: (1) Jika nilai probabilitas (sig) > 0,05 maka H0 diterima, yang berarti bahwa variabel independen tidak berpengaruh terhadap variabel dependen. (2) Jika nilai probabilitas (sig) $<0,05$ maka H0 ditolak, yang berarti bahwa variabel independen berpengaruh terhadap variabel dependen.

\section{ANALISIS HASIL DAN PEMBAHASAN}

\section{Statistik Deskriptif}

Pengolahan data ini menggunakan program Statistical Package for the Social Science (SPSS). Objek dalam penelitian ini adalah seluruh perusahaan manufaktur yang terdaftar di BEI periode 2016-2018 dengan total populasi sebanyak 153 perusahan manufaktur. Sampel dalam penelitian ini menggunakan teknik purposive sampling. Sampel yang memenuhi persyaratan sebanyak 72 perusahaan.

a. Ukuran perusahaan. Size diproksikan Ln Total Aset. Ukuran perusahaan mempunyai nilai minimum sebesar 25,22, nilai maksimum sebesar 34,09, nilai rata-rata (mean) sebesar 28,708, dan standar deviasi sebesar 1,72598. Total Aset paling rendah yaitu Primarindo Asia Infrastructure pada tahun 2017, nilai maksimum diperoleh dari total aset paling besar tahun 2016 yaitu Trisula Internasional.

b. Profitabilitas. Besarnya profitabilitas mempunyai nilai minimum sebesar 0,00 , nilai maksimum sebesar 0,53, nilai rata-rata (mean) sebesar 0,0617, dan standar deviasi sebesar 0,07739. Profitabilitas dengan nilai minimium Trisula Inernasional tahun 2016-2018., dan nilai maksimum Multi Bintang Indonesia tahun 2017.

c. Leverage. Besarnya Leverage mempunyai nilai minimum sebesar 0,00 , nilai maksimum sebesar 2, 06 , nilai rata-rata (mean) sebesar 0,4063, dan standar deviasi sebesar 0,25208 .

Sampel perusahaan yang menggunakan KAP The Big Four sebanyak 82 
sampel atau sebesar 38\%. Sedangkan sampel yang menggunakan KAP Non The Big Four sebanyak 134 sampel atau sebesar 62\%. Dari jumlah total sampel sebanyak 216 perusahaan terdapat 79 perusahaan yang melakukan penghindaran pajak atau sebesar $36,6 \%$. Sedangkan untuk perusahaan yang tidak melakukan penghindaran pajak sebanyak 137 perusahaan atau sebesar $63,4 \%$.

\section{Analisis Regresi Logistik}

\section{Menilai Keseluruhan Model Fit (Overall Model Fit)}

Langkah pertama adalah menilai Overall fit model terhadap data. Uji ini bertujuan untuk mengetahui apakah model fit dengan data saat sebelum maupun sesudah variabel independen dimasukkan ke dalam model. Pengujian ini dilakukan dengan membandingkan nilai -2 log Likelihood awal (block 0 : Beginning Block) sebelum dimasukkannya variabel independen ke dalam model dengan nilai -2 log Likelihood akhir (block 1: Method = Enter) susudah variabel independen dimasukkan ke dalam model. Hipotesis yang digunakan untuk menilai overall fit model adalah sebagai berikut: (1) Jika nilai -2 log Likelihood ada penurunan, maka H0 diterima, yang berarti bahwa model fit dengan data. (2) Jika nilai -2 log Likelihood tidak ada penurunan, maka $\mathrm{H} 0$ ditolak, yang berarti bahwa model tidak fit dengan data.

Hasil pengujian model fit dapat dilihat pada tabel berikut:

Tabel 1

Overall Model Fit (Block 0 : Beginning Block)

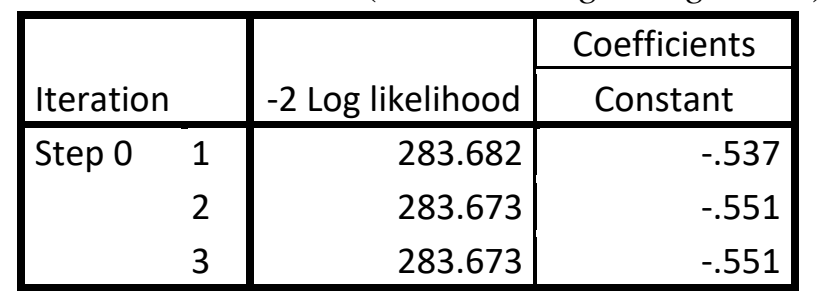

Sumber: Data diolah, 2020

Tabel 2

Overall Model Fit (Block $1:$ Method $=$ Enter $)$

\begin{tabular}{|c|c|c|c|c|c|c|}
\hline \multirow[b]{2}{*}{ Iteratio } & \multirow{2}{*}{$\begin{array}{c}-2 \text { Log } \\
\text { likelihood }\end{array}$} & \multicolumn{5}{|c|}{ Coefficients } \\
\hline & & Constant & $\mathrm{X} 1$ & $X 2$ & X3 & $X 4$ \\
\hline Step 1 & 272.625 & 4.939 & -3.276 & .739 & -.353 & .176 \\
\hline 12 & 271.652 & 6.409 & -4.084 & .966 & -.226 & .176 \\
\hline 3 & 271.578 & 7.094 & -4.478 & 1.026 & -.126 & .181 \\
\hline 4 & 271.578 & 7.161 & -4.517 & 1.032 & -.116 & .181 \\
\hline 5 & 271.578 & 7.161 & -4.517 & 1.032 & -.116 & 181 \\
\hline
\end{tabular}

Sumber: Data diolah, 2020 
Pada tabel 2 di atas dimana variabel independen tidak dimasukkan dalam model menunjukkan nilai -2 Log Likelihood awal sebesar 283,673. Pada tabel 2 pada saat variabel independen dimasukkan ke dalam model menunjukkan nilai -2 Log Likelihood akhir sebesar 271,578. Hal ini menunjukkan bahwa terdapat penurunan nilai -2 Log Likelihood yaitu sebesar 12,095. Penurunan nilai -2 Log Likelihood ini menunjukkan bahwa dengan memasukkan variabel independen ke dalam model dapat memperbaiki model fit serta menunjukkan model regresi yang lebih baik, yang berarti $\mathrm{HO}$ diterima, yang berarti bahwa model fit dengan data dan dapat melanjutkan proses pengujian selanjutnya

\section{Koefisien Determinasi (Nagelkere $R$ Square)}

Koefisiensi determinasi digunakan untuk mengetahui seberapa jauh kemampuan model variabel independen dalam menerangkan variasi variabel dependen. Pengujian ini bertujuan untuk mengetahui seberapa besar kombinasi variabel independen yaitu ukuran perusahaan, profitabilitas, leverage, dan kualitas audit mampu menerangkan variasi variabel yaitu penghindaran pajak. Dalam model regresi logistik besarnya koefisien determinasi ditunjukkan dengan nilai Nagelkere $R$ Square yang dapat diiterpretasikan seperti nilai $\mathrm{R}^{2}$ pada regresi berganda.

Tabel 3

Uji Koefisien Determinasi

\begin{tabular}{|l|r|r|r|}
\hline Step & -2 Log likelihood & Cox \& Snell R Square & Nagelkerke R Square \\
\hline 1 & $271.578^{\mathrm{a}}$ & .054 & .074 \\
\hline
\end{tabular}

Sumber: Data diolah, 2020

Pada tabel 3 di atas menunjukkan nilai Nagelkere $R$ Square yaitu sebesar 0,074 yang menunjukkan bahwa kemampuan variabel independen (ukuran perusahaan, profitabilitas, leverage, dan kualitas audit) dalam menjelaskan variabel dependen yaitu (penghindaran pajak sebesar 7,4\%), sedangkan sisanya sebesar 92,6\% dijelaskan oleh variabel lain diluar penelitian ini.

\section{Menilai Kelayakan Model Regresi (Hosmer and Lemeshow's Goodness of Fit Test)}

Dalam menilai kelayakan model regresi dapat diuji menggunakan Hosmer and Lemeshow's Goodness of Fit Test. Model ini bertujuan untuk menguji hipotesis bahwa data empirik cocok atau sesuai dengan model (tidak ada perbedaan antar model dengan data sehingga model dapat dikatakan fit) (Ghozali, 2016).

Tabel 4

Kelayakan Model Regresi

\begin{tabular}{|l|r|r|c|}
\hline Step & Chi-square & Df & Sig. \\
\hline 1 & 12.454 & & .132 \\
\hline
\end{tabular}

Sumber: Data diolah, 2020

Berdasarkan tabel 4 di atas menunjukkan nilai signifikan dari output Hosmer and Lemeshow Test adalah 0,132 dimana lebih besar dari 0,05 maka $\mathrm{H}_{\mathrm{o}}$ diterima. Dengan hasil tersebut dapat disimpulkan bahwa model dapat memprediksi nilai observasinya atau dapat dikatakan model dapat diterima karena cocok dengan data observasinya. 


\section{Matriks Klasifikasi}

Matriks klasifikasi bertujuan untuk melihat presentasi estimasi perusahaan yang melakukan penghindaran pajak dan perusahaan tidak melakukan penghindaran pajak. Berdasarkan pengujian yang dilakukan. dapat disimpulkan bahwa dari 137 perusahaan yang tidak melakukan penghindaran pajak yang benarbenar tidak melakukan penghindaran pajak adalah 124 perusahaan dan 13 perusahaan melakukan penghindaran pajak, sehingga ketepatan klasifikasi yang didapatkan oleh kategori perusahaan yang tidak melakukan penghindaran pajak sebesar 90,5\%. Sedangkan dari 79 perusahaan yang melakukan penghindaran pajak yang benar-benar melakukan penghindaran pajak sebanyak 12 perusahaan dan 67 perusahaan tidak melakukan penghindaran pajak, sehingga untuk kategori perusahaan yang melakukan penghindaran pajak memperoleh ketepatan klasifikasi sebesar $15,2 \%$. Secara keseluruhan dapat dikatakan bahwa tingkat ketepatan klasifikasi sebesar $63 \%$.

\section{Omnibus Test}

Pengujian pengaruh model secara simultan dalam penelitian ini menggunakan tabel Omnibus Tests of Model Coefficients. Uji ini mirip dengan uji F pada analisis regresi linier berganda dimana untuk mengetahui pengaruh variabel bebas secara simultan terhadap variabel terikat. Berikut ini adalah tabelnya:

Tabel 5

Uji Secara Simultan

Omnibus Tests of Model Coefficients

\begin{tabular}{|c|c|c|}
\hline Chi-square & Df & Sig. \\
\hline 12.095 & 4 & .017 \\
12.095 & 4 & .017 \\
12.095 & 4 & .017 \\
\hline
\end{tabular}

Sumber: Data diolah, 2020

Dari hasil omnibus test menunjukkan bahwa nilai p-value sebesar 0,017 < 0,05 . Nilai $p$-value yang menunjukkan lebih kecil dari tingkat signifikansi sebesar 0,05 , maka $\mathrm{H}_{0}$ ditolak yang berarti bahwa variabel independen berpengaruh simultan terhadap variabel dependen.

\section{Koefisien Regresi Logistik}

Pengujian hipotesis dalam penelitian ini bertujuan untuk mengetahui pengaruh ukuran perusahaan, profitabilitas, leverage, dan kualitas audit terhadap penghindaran pajak sebagai variabel dependen. Pengujian hipotesis ini dilakukan dengan menggunakan hasil uji regresi logistik yang ditujukkan dengan tabel hasil.

\section{Tabel 6}

Koefisien Regresi Model

Variables in the Equation

\begin{tabular}{|c|c|c|c|c|c|c|c|c|}
\hline & \multirow[b]{2}{*}{ B } & \multirow[b]{2}{*}{ S.E. } & \multirow[b]{2}{*}{ Wald } & \multirow[b]{2}{*}{ Df } & \multirow[b]{2}{*}{ Sig. } & \multirow[b]{2}{*}{$\operatorname{Exp}(B)$} & \multicolumn{2}{|c|}{ 95\% C.I.for $\operatorname{EXP}(B)$} \\
\hline & & & & & & & Lower & Upper \\
\hline Step $1^{\text {a }}$ X1 & -4.517 & 6.907 & .428 & 1 & .513 & .011 & .000 & 8267.949 \\
\hline
\end{tabular}




\begin{tabular}{|l|r|r|r|r|r|r|r|r|}
\hline $\mathrm{X} 2$ & 1.032 & .378 & 7.443 & 1 & .006 & 2.806 & 1.337 & 5.887 \\
$\mathrm{X} 3$ & -.116 & .563 & .043 & 1 & .836 & .890 & .296 & 2.681 \\
$\mathrm{X} 4$ & .181 & .362 & .250 & 1 & .617 & 1.199 & .589 & 2.439 \\
Constant & 7.161 & 9.981 & .515 & 1 & .473 & 1288.260 & & \\
\hline
\end{tabular}

Sumber: Data diolah, 2020

Dari hasil pengujian regresi logistik tersebut, maka persamaan regresinya adalah sebagai berikut:

$$
\begin{aligned}
\mathrm{Y}= & 7.161-4.517(\text { Ukuran Perusahaan })+1.032 \text { (Profitabilitas) }-0,116 \text { (Leverage) } \\
& +0,181 \text { (Kualitas Audit) }+\varepsilon
\end{aligned}
$$

\section{Analisis Regresi Linier Berganda}

Berikut ini adalah tabel hasil analisis regresi linier berganda dengan bantuan SPSS. Berdasarkan tabel di bawah ini, maka dapat dibuat persamaan regresi linier berganda sebagai berikut :

$$
\mathrm{Y}=0,183+0,006 \mathrm{SIZE}+0,104 \mathrm{ROA}+0,076 \mathrm{DER}+\varepsilon
$$
berikut:

Berdasarkan persamaan regresi di atas, maka dijelaskan analisis sebagai

1. Nilai konstanta pada persamaan regresi di atas sebesar 7,161 artinya apabila variabel ukuran perusahaan, profitabilitas, leverage, dan kualitas audit bernilai nol (tidak ada) maka nilai penghindaran pajak sebesar 7,161.

2. Koefisien regresi variabel ukuran perusahaan sebesar $-4,517$. koefisien negatif menunjukkan setiap kenaikan ukuran perusahaan sebesar 1 (satu) poin maka penghindaran pajak akan mengalami penurunan sebesar $-4,517$.

3. Koefisien regresi variabel profitabilitas sebesar 1,032. koefisien positif menunjukkan setiap kenaikan profitabilitas sebesar 1 (satu) poin penghindaran pajak akan mengalami kenaikan sebesar 1,032.

4. Koefisien regresi variabel leverage sebesar -0,116. Koefisien negatif menunjukkan setiap kenaikan leverage sebesar 1 (satu) poin maka penghindaran pajak akan mengalami penurunan sebesar -0,116.

5. Koefisien regresi variabel kualitas audit sebesar 0,181. Koefisien negatif menunjukkan setiap kenaikan kualitas audit sebesar 1 (satu) poin maka penghindaran pajak akan mengalami kenaikan sebesar 0,181 .

Berdasarkan tabel analisis regresi logistik di atas, maka dapat dijelaskan mengenai pengaruh secara parsial masing-masing variabel independen sebagai berikut:

\section{a. Pengaruh Ukuran Perusahaan Size terhadap Penghindaran Pajak}

Hasil pengujian menunjukkan bahwa koefisien dari ukuran perusahaan sebesar -4,517 dengan tingkat signifikan sebesar 0,513. Tingkat signifikansi 0,513 $>$ 0,05 memberi kesimpulan $\mathrm{H}_{01}$ diterima dan $\mathrm{H}_{\mathrm{a} 1}$ ditolak, yang berarti bahwa ukuran perusahaan tidak berpengaruh terhadap penghindaran pajak. Hal ini menunjukan bahwa besar atau kecilnya ukuran perusahaan tidak mempengaruhi pihak manajemen untuk melakukan tindakan penghindaran pajak dikarenakan setiap perusahaan mempunyai kewajiban yang sama yaitu membayar pajak kepada negara terlepas dari besar atau kecilnya ukuran perusahaan. 
Hal ini didukung pula dengan data penelitian yaitu perusahaan Trisula Internasional tahun 2016 memiliki nilai ukuran perusahaan sebesar 34,09 dengan nilai CETR sebesar 0,42 sementara perusahaan Primarindo Asia Infrastructure tahun 2017 memiliki nilai ukuran perusahaan sebesar 25,22 dengan nilai CETR sebesar 0,80 .

Hasil penelitian ini didukung oleh penelitian Annisa (2017) yang menyatakan bahwa size tidak berpengaruh terhadap penghindaran pajak. Hal ini dikarenakan semakin besar ukuran suatu perusahaan maka semakin menjadi pusat perhatian dari pemerintah dan akan menimbulkan kecenderungan bagi para manajer perusahaan untuk berlaku patuh atau pasif dalam melakukan penghindaran perpajakan.

\section{b. Pengaruh profitabilitas terhadap penghindaran pajak}

Hasil pengujian menunjukkan bahwa koefisien dari ukuran perusahaan sebesar 1,032 dengan tingkat signifikan sebesar 0,006. Tingkat signifikansi 0,006 < 0,05 memberi kesimpulan H03 ditolak dan Ha3 diterima, yang berarti bahwa profitabilitas berpengaruh positif terhadap penghindaran pajak.

Profitabilitas yang tinggi menunjukkan bahwa perusahaan mampu mendapatkan laba yang maksimal. Semakin tinggi laba perusahaan maka semakin tinggi beban pajaknya. Perusahaan yang memiliki profitabilitas tinggi memiliki kesempatan untuk memposisikan diri dalam tax planning yang mengurangi jumlah beban pajaknya, hal ini mendorong perusahaan untuk melakukan tindakan penghindaran pajak.

Dari hasil penelitian yang dilakukan oleh Ida Ayu Rosa Dewinta dan Putu Ery Setiawan (2016) bahwa ROA berpengaruh terhadap penghindaran pajak dikarenakan perusahaan mampu mengelola asetnya dengan baik salah satunya dengan memanfaatkan beban penyusutan atas pengeluaran untuk memperoleh harta tetap berwujud dan amortisasi atas pengeluaran untuk memperoleh harta tetap tidak berwujud yang mempunyai masa manfaat lebih dari satu tahun dapat digunakan sebagai pengurang laba kena pajak perusahaan.

\section{c. Pengaruh leverage terhadap penghindaran pajak}

Berdasarkan hasil pengujian hipotesis yang telah dilakukan, diperoleh hasil koefisien dari leverage sebesar -0,116 dengan tingkat signifikan sebesar 0,836. Tingkat signifikansi 0,836 > 0,05 memberi kesimpulan H03 diterima dan Ha3 ditolak, yang berarti bahwa leverage tidak berpengaruh terhadap penghindaran pajak. Hal ini menunjukan besar atau kecilnya hutang perusahaan tidak memiliki pengaruh terhadap penghindaran pajak.

Leverage pada perusahaan adalah tingkat dukungan modal perusahaan yang diperoleh dari pihak luar perusahaan. Semakin besar tingkat modal perusahaan maka akan semakin tinggi risiko yang akan dihadapi perusahaan seperti kebangkrutan dan biaya bunga yang tinggi.

Hasil penelitian ini didukung oleh penelitian (Tommy Kurniasih \& Maria M. Ratna Sari, 2013) Leverage tidak bepengaruh hal ini terjadi dikarenakan semakin tinggi tingkat hutang suatu perusahaan maka pihak manajemen akan lebih konservatif dalam melakukan pelaporan keuangan atau operasional perusahaan. Pihak manajemen akan lebih berhati-hati dan tidak akan mengambil resiko yang 
tinggi untuk melakukan aktivitas penghindaran pajak guna menekan beban pajaknya. Apabila hutang digunakan dalam jumlah yang besar maka dapat menimbulkan kerugian bagi perusahaan.

\section{d. Pengaruh kualitas audit terhadap penghindaran pajak}

Berdasarkan hasil pengujian hipotesis yang telah dilakukan, diperoleh hasil koefisien dari kualitas audit sebesar 0,181 dengan tingkat signifikan sebesar 0,617. Tingkat signifikansi 0,617 > 0,05 memberi kesimpulan H04 diterima dan Ha4 ditolak, yang berarti bahwa kualitas audit tidak berpengaruh terhadap penghindaran pajak.

Hal ini berarti kantor akuntan publik yang termasuk dalam The Big Four maupun Non The Big Four memiliki auditor-auditor yang professional dan kompeten dalam melakukan audit laporan keuangan perusahaan sehingga menghasilkan kualitas audit yang sama baiknya. Meskipun begitu, perusahaan yang diaudit oleh KAP The Big Four cenderung lebih dipercayai fiskus dibandingkan KAP Non The Big Four karena KAP The Big Four dianggap memiliki reputasi yang baik dan memiliki integritas yang tinggi. Kualitas audit tidak berpengaruh terhadap penghindaran pajak dikarenakan auditor KAP The Big Four maupun KAP Non The Big Four hanya sebatas mengaudit laporan keuangan tersebut dan tidak menemukan adanya pelanggaran dikarenakan memang penghindaran pajak bukanlah merupakan suatu pelanggaran namun sebuah upaya untuk pengurangan pajak secara legal dengan memanfaatkan celah-celah dari ketentuan perundangundangan perpajakan yang berlaku.

Hasil penelitian ini sesuai atau sejalan dengan penelitian yang dilakukan oleh Sri Mulyani (2018), Fitri Darmayanti dan Tridahus Susanto (2015). Sementara hasil penelitian ini tidak selaras dengan penelitian yang dilakukan Arry Eksandy (2017).

\section{Kesimpulan dan Saran \\ Kesimpulan}

Adapun kesimpulan dalam penelitian ini adalah sebagai berikut:

1. Ukuran perusahaan tidak berpengaruh terhadap penghindaran pajak.

2. Profitabilitas berpengaruh terhadap penghindaran pajak.

3. Leverage tidak berpengaruh terhadap penghindaran pajak.

4. Kualitas audit tidak berpengaruh terhadap penghindaran pajak.

\section{Saran}

Berdasarkan kesimpulan diatas, maka peneliti mengajukan beberapa saran yaitu sebagai berikut :

1. Bagi peneliti selanjutnya diharapkan untuk mempertimbangkan dalam penambahan variabel independen lain seperti umur perusahaan dan komite audit.

2. Penelitian selanjutnya diharapkan dapat lebih difokuskan pada sub sektor industri manufaktur yang terdaftar di Bursa Efek Indonesia. Memperpanjang periode waktu penelitian agar dapat memberikan gambaran yang lebih luas lagi mengenai pengaruhnya terhadap penghindaran pajak. 


\section{DAFTAR PUSTAKA}

Agus, Sartono. 2012. Manajemen Keuangan Teori dan Aplikasi. Edisi 4. Yogyakarta: BPFE.

Annisa. 2017. Pengaruh Return on Asset, Leverage, Ukuran Perusahaan dan Koneksi Politik Terhadap Penghindaran Pajak. JOM Fekon. Vol.4.No.1.Februari.2017.

Cahyono, Deddy Dyas. 2016. Pengaruh Komite Audit, Kepemilikan Institusional, Dewan Komisaris, Ukuran Perusahaan (Size), Leverage (DER) dan Profitabilitas (ROA) Terhdap Tindakan Penghindaran Pajak (Tax Avoidance) Pada Perusahaan Perbankan Yang Listing BEI Periode 2011-2013. Journal of Accounting Vlume 2 No.2. Maret 2016. Fakultas Ekonomika dn Bisnis Unpad.

Darmayanti, Fitri dan Susanto, Tridahus, 2015. Pengaruh Komite Audit, Kualitas Audit, Kepemilikan Institusional, Resiko Perusahaan, dan Return On Assets (ROA) Terhadap Tax Avoidance. Jurnal Bisnis dan Manajemen. Vol. 5, No. 2, Oktober, 2015.

Eksandy, Arry. 2017. Pengaruh Komisaris Independen, Komite Audit dan Kualitas Audit Terhadap Penghindaran Pajak (Tax Avoidance) (Studi Empiris Pada Sektor Industri Barang Konsumsi yang Terdaftar di Bursa Efek Indonesia Periode 2010-2014). Compotitive Journal Vol.1 No.1. Januari-Juni 2017. Fakultas Ekonomi dan Bisnis Universitas Muhammadiyah Tangerang.

Ghozali, Imam. 2016. Aplikasi Analisis Multivariate Dengan Program IBM SPSS. Semarang: Undip.

Hartono, Jogiyanto. 2013. Teori Portofolio dan Analisis Investasi Edisi 8. Yogyakarta: BPFE.

Kasmir. 2014. Analisis Laporan Keuangan, Edisi Pertama, Cetakan Ketujuh. Jakarta: Rajawali Persada.

Kasus penghindaran pajak Perusahaan Coco Cola Indonesia. 2014. https://ekonomi.kompas.com/read/2014/06/13/1135319/Coca.Cola.Diduga.A kali.Seto diakses pada 14 Februari 2020.

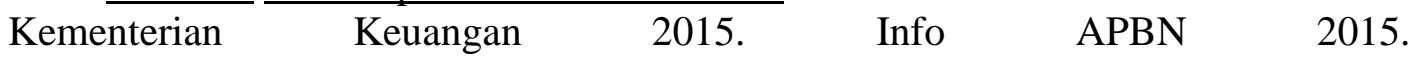
https://www.kemenkeu.go.id/apbn2015 diakses pada 14 Februari 2020.

Pohan, Chairil A. (2013). Manajemen Perpajakan. Jakarta: Gramedia Pustaka Utama.

Prawira, Yudi Mufti. 2016. Pengaruh Return On Assets, Corporate Governance, Ukuran Perusahaan Terhadap Tax Avoidance. Jurusan Akuntansi Fakultas Ekonomi Universitas Negeri Padang.

Suandy, Early. 2013. Perencanaan Pajak. Jakarta: Salemba Empat.

Sugiyono. 2016. Metode Penelitian Kuantitatif, Kualitataif dan R\&D. Bandung: Alfabeta.

Tandiontong, Mathius. 2015. Kualitas Audit dan Pengukurannya. Bandung: Alfabeta.

Undang-Undang Nomor 16 Tahun 2009 tentang Ketentuan Umum Perpajakan.

Undang-Undang No. 36 Tahun 2008 tentang pajak penghasilan.

Zain, Mohammad. 2007. Manajemen Perpajakan. Jakarta: Salemba Empat, Edisi 3.

Jurnal Ilmiah Akuntansi dan Ekonomi Volume. 5 Nomor. 2, Agustus 2020 Hal. 102 


\title{
PENGARUH KESADARAN WAJIB PAJAK, MODERNISASI SISTEM PERPAJAKAN, DAN SANKSI PERPAJAKAN DALAM MENINGKATKAN KEPATUHAN WAJIB PAJAK ORANG PRIBADI (Studi Empiris Pada Masyarakat Di Lingkungan RT 12 Kelurahan Kebayoran Lama Selatan)
}

\author{
Galih Chandra Kirana, SE., M.Ak, \\ Azmi Maliki
}

chandra.galih13@gmail.com, azmimaliki55555@gmail.com

\author{
Fakultas Ekonomi dan Bisnis - Program Studi Akuntansi \\ Universitas Satya Negara Indonesia
}

\begin{abstract}
ABSTRAK
Tujuan penelitian ini adalah untuk mengetahui pengaruh kesadaran wajib pajak, modernisasi sistem perpajakan, dan sanksi perpajakan dalam meningkatkan kepatuhan wajib pajak orang pribadi. Populasi dalam penelitian ini adalah masyarakat yang berada di lingkungan RT 12 Kelurahan Kebayoran Lama Selatan. Sample yang digunakan dalam penelitian ini sebanyak 50 responden. Data penelitian ini adalah data primer yang diperoleh melalui penyebaran kuesioner. Teknik pengambilan sample ini menggunakan metode Purposive Sampling, sedangkan metode pengolahan data yang digunakan peneliti adalah analisis linear berganda dengan bantuan SPSS versi 22. Hasil penelitian ini menunjukan bahwa kesadaran wajib pajak berpengaruh terhadap kepatuhan wajib pajak, sedangkan modernisasi sistem perpajakan tidak berpengaruh terhadap kepatuhan wajib pajak , sanksi perpajakan tidak berpengaruh terhadap kepatuhan wajib pajak, dan pengaruh simultan kesadaran wajib pajak, modernisasi sistem perpajakan, sanksi perpajakan berpengaruh terhadap kepatuhan wajib pajak.

Kata Kunci : Kesadaran wajib pajak, modernisasi sistem perpajakan, sanksi perpajakan, dan kepatuhan wajib pajak orang pribadi

The purpose of this study was to determine the effect of awareness of taxpayers, the modernization of the taxation system, and taxation sanctions in improving the compliance of individual taxpayers. The population in this study are the people who are in the RT 12 neighborhood of Kebayoran Lama Selatan Village. The sample used in this study were 50 respondents. The data of this study are primary data obtained through questionnaires. This sampling technique uses the Purposive Sampling method, while the data processing method used by researchers is multiple linear analysis with the help of SPSS version 22. The results of this study indicate that the effect of taxpayer awareness influences taxpayer compliance, whereas the modernization of the taxation system does not affect compulsory compliance tax, tax sanctions does not affect taxpayer compliance, and influence of taxpayer awareness, modernization of the taxation system, tax sanctions affect taxpayer compliance.
\end{abstract}

Keywords: Awareness of taxpayers, modernization of the taxation system, taxation sanctions, and individual taxpayer compliance.

Jurnal Ilmiah Akuntansi dan Ekonomi Volume. 5 Nomor. 2, Agustus 2020 Hal. 103 


\section{PENDAHULUAN}

Pajak memiliki peranan yang sangat penting bagi penerimaan kas negara, dimana pajak merupakan iuran yang berasal dari rakyat untuk kas negara yang sifatnya memaksa tanpa ada imbalan secara langsung, dengan tujuan untuk kesejahteraan rakyat itu sendiri. Dari awal berdiri sampai saat ini, Direktoorat Jenderal Pajak (DJP) telah beberapa kali menjalankan agenda perubahan. Perubahan pertama yang cukup besar terjadi pada tahun 1983 dimana beberapa undang-undang baru di bidang perpajakan disahkan untuk mengganti undangundang lama peninggalan Belanda. Sistem pemungutan pajak diubah dari Official Assesment menjadi Self Assesment. Seiring dengan berjalannya waktu melihat perubahan itu belum cukup optimal, sehingga DJP merasa perlu untuk mengembangkan dan menyempurnakan struktur organisasi, pembentukan kantor, dan penerapan sistem modern. Modernisasi lebih lanjut ditandai dengan penerapan teknologi informasi yang baru dalam pelayanan berupa online payment, e-SPT, $e$ Filling, e-Registration, dan sistem informasi DJP.

Tingkat kepatuhan wajib pajak setelah dilakukan modermisasi sistem masih bersifat fluktuatif. Berdasarkan informasi yang disampaikan pemerintah dalam Nota Keuangan beserta RAPBN 2020, jumlah wajib pajak pada 2019 tercatat sebanyak 42 juta. Jumlah tersebut naik dari tahun sebelumnya sebanyak 38,7 juta wajib pajak. Pada 2015, 2016, dan 2017, jumlah wajib pajak tercatat sebanyak 30 juta, 32,8 juta, dan 36,0 juta. Data otoritas pajak sampai dengan Juli 2019, menunjukkan dari jenis wajib pajaknya, wajib pajak karyawan termasuk yang paling patuh di antara wajib pajak lainnya dengan rasio kepatuhan pada angka $73,6 \%$, sedangkan kelompok korporasi hanya 57,28\% dan wajib pajak orang kaya atau non-karyawan masih di bawah $50 \%$ atau $42,75 \%$. Peningkatan jumlah wajib pajak tersebut diikuti dengan perkembangan kepatuhan pelaporan surat pemberitahuan (SPT). Meskipun demikian, pergerakan kepatuhan formal ini lebih fluktuatif dibandingkan penambahan jumlah wajib pajak. Pada tahun 2015 rasio kepatuhan penyampaian SPT sebesar 60,4\%, pada tahun 2016 60,7\% dan pada tahun 2017 terjadi lonjakan rasio kepatuhan yang signifikan mencapai 72,6\%. Pada 2018, rasio kepatuhan mengalami penurunan menjadi 71,1\%. Pada Juli 2019 rasio kepatuhan mengalami penurunan kembali menjadi 67,2\%.

Berdasarkan latar belakang penelitian tersebut, maka yang menjadi pokok permasalahan dalam penelitian ini adalah :

1. Apakah kesadaran wajib pajak berpengaruh terhadap kepatuhan wajib pajak orang pribadi?

2. Apakah modernisasi sistem perpajakan berpengaruh terhadap kepatuhan wajib pajak?

3. Apakah sanksi perpajakan berpengaruh terhadap kepatuhan wajib pajak orang pribadi?

4. Apakah kesadaran wajib pajak, modernisasi sistem perpajakan, sanksi perpajakan secara bersama-sama berpengaruh terhadap kepatuhan wajib pajak? 


\section{Definisi Perpajakan}

\section{LANDASAN TEORI}

Menurut Undang-Undang No. 16 Tahun 2009 pasal 1 ayat 1 tentang UndangUndang Ketentuan Umum dan Tata Cara Perpajakan, pajak adalah kontribusi wajib kepada negara yang terutang oleh orang pribadi atau badan yang bersifat memaksa berdasarkan Undang-Undang, dengan tidak mendapatkan imbalan secara langsung dan digunakan untuk keperluan negara sebesar-besarnya bagi kemakmuran rakyat.

\section{Kepatuhan Wajib Pajak.}

Menurut Siti Kurnia Rahayu (2013:139) menyatakan bahwa kepatuhan wajib pajak adalah kepatuhan dalam mendaftarkan diri, kepatuhan untuk menyetorkan kembali SPT, kepatuhan dalam perhitungan dan pembayaran pajak terutang serta kepatuhan dalam pembayaran tunggakan.

Kepatuhan wajib pajak menurut Gunadi (2013:94), yaitu kepatuhan dalam hal ini diartikan bahwa wajib pajak mempunyai kesediaan untuk memenuhi kewajiban perpajakannya sesuai dengan aturan yang berlaku tanpa perlu diadakan pemeriksaan, investigasi seksama, peringatan ataupun ancaman dan penerapan sanksi baik hukum maupun administrasi.

\section{Kesadaran Wajib Pajak}

Menurut Anshari Ritonga (2011:15) menyatakan bahwa, kesadaran wajib pajak merupakan perilaku wajib pajak berupa pandangan atau persepsi yang melibatkan keyakinan, pengetahuan, dan penalaran serta kecenderungan untuk bertindak sesuai dengan stimulus yang diberikan oleh sistem dan ketentuan perpajakan yang berlaku.

Menurut Siti Kurnia Rahayu (2017:10), kesadaran wajib pajak merupakan suatu kondisi dimana wajib pajak mengerti dan memahami arti, fungsi maupun tujuan pembayaran pajak kepada negara. Dengan kesadaran wajib pajak yang tinggi akan memberikan pengaruh terhadap peningkatan kepatuhan pajak yang lebih baik lagi.

Menurut Erly Suandy (2016:35), menyatakan bahwa kesadaran wajib pajak artinya wajib pajak mau dengan sendirinya melakukan kewajiban perpajakannya seperti mendaftarkan diri, menghitung, membayar dan melaporkan jumlah pajak terutang.

\section{Modernisasi Sistem Perpajakan}

Menurut Siti Kurnia Rahayu (2013:109), modernisasi sistem perpajakan yang dilakukan merupakan bagian dari reformasi perpajakan secara komprehensif sebagai satu kesatuan dilakukan terhadap tiga bidang pokok yang secara langsung menyentuh pilar perpajakan yaitu bidang administrasi, bidang peraturan dan bidang pengawasan.

Menurut Liberti Pandiangan (2014:26) modernisasi perpajakan adalah perubahan dalam sistem administrasi dan pembentukan mental aparat pegawai pajak dimana dibentuk suatu sistem guna meningkatkan pelayanan kepada wajib pajak dengan memanfaatkan teknologi informasi yang mutakhir yang diharapkan dapat meningkatkan kepatuhan wajib pajak dan nantinya dapat meningkatkan penerimaan pajak.

\section{Sanksi Perpajakan}

Sanksi perpajakan menurut Aristanti Widyaningsih (2013:312), adalah sanksi berupa administrasi dan pidana yang dikenakan terhadap setiap orang yang 
melakukan pelanggaran perpajakan yang secara nyata telah diatur dalam undangundang.

Menurut Mardiasmo (2016:62), mengatakan bahwa sanksi perpajakan merupakan jaminan bahwa ketentuan peraturan perundang-undangan perpajakan (norma perpajakan) akan dituruti, ditaati, dipatuhi, atau bias dengan kata lain sanksi perpajakan merupakan alat pencegah (preventif) agar wajib pajak tidak melanggar norma perpajakan.

\section{METODOLOGI PENELITIAN}

Penelitian ini dilakukan sejak bulan Mei sampai dengan bulan Juli 2020. Penelitian ini merupakan penelitian kuantitatif, dimana data yang digunakan oleh peneliti didapat dari kuesioner yang disebarkan kepada wajib pajak orang pribadi di lingkungan RT 12 Kelurahan Kebayoran Lama Selatan. Desain penelitian yang digunakan adalah Penelitian Kausal yang merupakan metode penelitian untuk mengetahui hubungan satu atau lebih variable bebas (independen variabel) terhadap variable terikat (dependen variabel). Variabel bebas (independen variabel) ini adalah kesadaran wajib pajak, modernisasi sistem perpajakan, sanksi perpajakan. Serta untuk variable terikatnya (dependen variabel) adalah kepatuhan wajib pajak

\section{Populasi dan Sampel}

Dalam penelitian ini, populasinya adalah wajib pajak orang pribadi yang berada di lingkungan RT 12 Kelurahan Kebayoran Lama Jakarta Selatan. Metode yang digunakan adalah nonprobability sampling dengan teknik sample sampling pursposive. Sampling purposive adalah teknik penentuan sample dengan pertimbangan tertentu (Sugiono, 2016:85). Purposive Sampling yaitu metode pengambilan sample berdasarkan kriteria tertentu yang ditetapkan peneliti secara objektif. Hal tersebut disebabkan karena keterbatasan dana, tenaga dan waktu serta ditengah pandemi COVID-19. Sample dalam penelitian ini yaitu masyarakat yang berada di lingkungan RT 12 yang memiliki kriteria penentu sample yaitu memiliki Nomor Pokok Wajib Pajak serta penghasilan PTKP $\geq 54.000 .000 /$ tahun.

\section{Analisis Data}

\section{Uji Validitas Data}

Uji Validitas digunakan untuk mengukur sah atau valid tidaknya suatu kuesioner. Menurut Ghozali (2016: 51), suatu kuesioner dikatakan valid jika pertanyaan pada kuesioner mampu untuk mengungkapkan sesuatu yang akan di ukur dengan kuesioner tersebut. Pengujian ini menggunakan metode pearson correlation. Hasil uji validasi karena korelasi antara masing-masing butir pertanyaan memiliki $\mathrm{p}$ value $\leq 0.05$.

Uji Validitas dilakukan dengan membandingkan nilai $r$ hitung dengan $r$ tabel untuk degree of freedom $(\mathrm{df})=\mathrm{n}-2$. Dengan membandingkan nilai $\mathrm{r}$ hitung dengan hasil output (Corrected item-total correlations) dengan $r$ tabel, jika $r$ hitung lebih besar dari $r$ tabel maka butir pernyataan tersebut dikatakan valid, tetapi jika $r$ hitung lebih kecil dari pada $r$ tabel maka butir pernyataan tersebut tidak valid (Glozali, 2016:53).

\section{Uji Reliabilitas Data}

Uji Reliabilitas adalah alat untuk mengukur suatu kuesioner tingkat konsistensi atau stabil apabila dilakukan berulang kali dengan asumsi pada kondisi yang sama. Pengujian Reliabilitas menggunakan cronbach alpha. Suatu 
instrument dikatakan reliabel jika nilai cronbach alpha lebih besar dari 0,70 (Ghozali, 2016:48)

\section{Uji Asumsi Klasik}

Merupakan pengujian yang bertujuan untuk memastikan bahwa data yang diperoleh dapat di analisis dengan metode analisis regresi, uji asumsi klasik terdiri dari uji normalitas, uji multikoleniaritas dan uji heteroskedatisitas.

\section{a. Uji Normalitas}

Menurut Ghozali (2016:154), Uji Normalitas digunakan untuk menguji apakah dalam model regresi variabel independen dan variabel dependen atau keduanya mempunyai distribusi normal atau tidak. Uji Normalitas data dapat dilakukan dengan menggunakan One Sample Kolmogorov Smirnov yaitu dengan ketentuan apabila nilai signifikan diatas 0,05 maka data terdistribusi normal, jika hasil One Sample Kolmogorov Smirnov menunjukan nilai signifikan dibawah 0,05 maka data tidak terdistribusi normal.

\section{b. Uji Multikolinearitas}

Multikoliniearitas bertujuan untuk menguji apakah model regresi ditemukan adanya korelasi antar variabel bebas (independen).Model regresi yang baik seharusnya tidak terjadi korelasi diantara variabel independen. (Ghozali, 2016;103).Uji ini dilakukan dengan melihat nilai Tolerance dan Variance Inflation Factors (VIF). Dikatakan bebas multikolinieritas apabila nilai tolerance $>0,10$ dan nilai $\mathrm{VIF}<10$. Jadi bila nilai tolerance $<0,10$ dan VIF $>10$ berarti terdapat kasus multikolinearitas.

\section{c. Uji Heterokedastisitas}

Uji ini bertujuan untuk menguji apakah dalam sebuah model regresi terjadi ketidaknyamanan varian dari residual satu pengamatan ke pengamatan lain. Jika varian berbeda, disebut heteroskedastisitas. Cara untuk mengetahui ada tidaknya heteroskedastisitas dalam suatu model regresi linier berganda yaitu dengan uji sebagai berikut :

\section{Uji Sccatterplot}

Cara mendeteksi ada tidaknya heteroskedastisitas dapat dilakukan dengam melihat ada tidaknya pola tertentu pada grafik scatterplot antara SRESID dan ZPRED. Jika ada pola tertentu seperti titik-titik yang ada membentuk pola tertentu yang teratur (bergelombang, melebar kemudian menyempit), maka mengindikasikan telah terjadi heteroskedastisitas. Namun jika tidak ada pola yang jelas serta titik angka 0 pada sumbu Y, maka tidak terjadi terjadi heteroskedastisitas (Ghozali, 2016;134).

\section{Uji Glesjer}

Uji Glesjer yaitu uji hipotesis untuk mengetahui apakah sebuah model regresi memiliki indikasi heterokedastisitas dengan cara meregres absolud residual. Dasar pengambilan keputusan menggunakan uji glesjer yaitu :

a. Jika nilai signifikansi $>0,05$ maka data tidak terjadi heterokedastisitas.

b. Jika nilai signifikansi $<0,05$ maka data terjadi heterokedastisitas.

\section{Uji Autokolerasi}

Menurut Ghozali (2016:107) uji ini bertujuan menguji apakah sebuah regresi linier ada kolerasi anatara kesalahan pengganggu pada periode $\mathrm{t}$ dengan kesalahan pada periode $\mathrm{t}-1$ sebelumnya. Cara untuk melakukan pengujian terhadap asumsi autokorelasi, salah satunya adalah 
Durbing-Waston (DW) test. Persyaratan yang harus terpenuhi adalah tidak adanya autokorelasi dalam uji DW dengan ketentuan sebagai berikut :

\begin{tabular}{|l|c|c|}
\hline \multicolumn{1}{|c|}{ Hipotesis Nol } & Keputusan & Jika \\
\hline Tidak ada autokorelasi positif & Tolak & $0<\mathrm{d}<\mathrm{dl}$ \\
Tidak ada autokorelasi positif & No desicison & $\mathrm{d} l \leq \mathrm{d} \leq \mathrm{du}$ \\
Tidak ada autokorelasi negatif & Tolak & $4-\mathrm{dl}<\mathrm{d}<4$ \\
Tidak ada autokorelasi negatif & No desicison & $4-\mathrm{du} \leq \mathrm{d} \leq 4-\mathrm{dl}$ \\
Tidak ada autokorelasi, & Tidak ditolak & $\mathrm{du}<\mathrm{d}<4-\mathrm{du}$ \\
Positif atau negative & & \\
\hline
\end{tabular}

\section{Analisis Regresi Linier Berganda}

Menurut Sugiyono (2016:192), analisis regresi linier berganda adalah analisis yang digunakan untuk mengetahui pengaruh antara dua atau lebih variable independen terhadap variable dependennya. Pengujian atas variable-variabel penelitian menggunakan analisis regresi linier berganda dimaksudkan untuk mengetahui apakah terdapat pengaruh yang signifikan atau tidak antara semua variable independen terhadap variable dependen.

Model yang digunakan dalam penelitian ini adalah :

$\mathrm{Y}=\alpha+\beta 1 \mathrm{X} 1+\beta 2 \mathrm{X} 2+\beta 3 \mathrm{X} 3+\mathrm{e}$

Keterangan :

Y : Kepatuhan wajib pajak

A : Konstanta

$\mathrm{X} 1$ : Kesadaran wajib pajak

$\mathrm{X} 2$ : Modernisasi sistem perpajakan

X3 : Sanksi Perpajakan

$\beta 1$ : Koefisien regresi variabel kesadaran wajib pajak

$\beta 2$ : Koefisien regresi variabel modernisasi sistem perpajakan

$\beta 3$ : Koefisien regresi variabel sanksi perpajakan

e : error/variabel lain yang mempengaruhi $\mathrm{Y}$

\section{Uji Hipotesis}

Uji hipotesis digunakan untuk menguji apakah hasil koefisien regresi yang diperoleh signifikan. Pengujian ini setidaknya terdiri dari uji parsial (Uji t) uji simultan (Uji f), dan.uji koefesien determinasi (Uji $\mathrm{R}^{2}$ )

\section{a. Uji Parsial (Uji t)}

Uji t bertujuan untuk menguji pengaruh secara parsial dari masing-masing variabel bebas terhadap variabel terikat. Uji t dilakukan untuk membandingkan $t$ hitung dengan $t$ tabel. Pengambilan keputusan uji t adalah sebagai berikut :

1. Jika signifikan $>0,05$ t hitung $<\mathrm{t}$ tabel maka Ho diterima dan Ha tidak diterima, artinya variabel independen secara parsial tidak berpengaruh terhadap variabel dependen.

2. Jika signifikan $<0,05 \mathrm{t}$ hitung $>\mathrm{t}$ tabel maka Ho tidak diterima dan $\mathrm{Ha}$ diterima, artinya variabel independen secara parsial berpengaruh terhadap variabel dependen.

\section{b. Uji Simultan (Uji f)}


Uji Simultan (Uji f) bertujuan untuk mengetahui ada atau tidaknya pengaruh simultan variabel-variabel independen terhadap variabel terikat. Kriteria pengambilan keputusan dalam pengujian yang menggunakan $\mathrm{p}$ value atau $\mathrm{F}$ adalah jika $\mathrm{p}$ value $<0,05$ atau $\mathrm{F}$ hitung $\geq \mathrm{F}$ tabel maka Ha diterima. Sebaliknya, jika $\mathrm{p}$ value $\geq 0,05$ atau $\mathrm{F}$ hitung $<\mathrm{F}$ tabel maka Ha ditolak. (Ghozali,2016: 99).

\section{c. Uji Koefisien Determinasi (Uji $\mathbf{R}^{2}$ )}

Menurut Ghozali (2016:65) Uji Koefisien Determinasi (Uji $\mathrm{R}^{2}$ ) bertujuan untuk mengukur sejauh mana variabel bebas dapat menjelaskan variasi variabel terikat secara simultan. Nilai koefisien determinasi ini adalah antara nol sampai dengan satu $\left(0<\mathrm{R}^{2}<1\right)$. nilai $\mathrm{R}^{2}$ yang kecil mengandung arti bahwa kemampuan variabel bebas dalam menjelaskan variasi variabel terikat sangat terbatas. Sebaliknya, nilai $\mathrm{R}^{2}$ yang hampir mendekati satu mengandung arti bahwa variabel bebas memberikan hampir semua informasi yang dibutuhkan untuk memprediksi variasi variabel independen.

\section{Deskritif Data}

\section{ANALISIS DAN PEMBAHASAN}

\section{a. Hasil Kuesioner Yang Disebar}

Jumlah penduduk dalam lingkungan RT 12 Kelurahan Kebayoran Lama sebanyak 145 orang, namun yang memenuhi kriteria sampel sebanyak 50 responden, sedangkan 95 responden tidak memenuhi kriteria sampel, sehingga kuesioner yang diberikan berdasarkan yang telah memenuhi kriteria sampel yaitu 50 responden. Berikut adalah hasil penyebaran kuesioner pada tabel berikut ini:

\begin{tabular}{|c|c|}
\hline Keterangan & Jumlah \\
\hline Jumlah penduduk di lingkungan RT 12 & 145 \\
\hline Penduduk yang tidak memiliki NPWP & 95 \\
\hline Jumlah sampel penelitian & 50 \\
\hline
\end{tabular}

Sumber Data : Diolah sendiri

\section{b. Profil Responden Berdasarkan Jenis Kelamin}

Berdasarkan jenis kelamin, peneliti membagi menjadi dua kategori yaitu pria dan wanita. Pada tabel berikut dapat dilihat persentase responden laki laki dan perempuan sebagai berikut :

\begin{tabular}{|ll|r|r|r|r|}
\hline & & & & Cumulative \\
& Frequency & Percent & Valid Percent & \multicolumn{2}{c|}{ Percent } \\
\hline Valid & Pria & 45 & 90.0 & 90.0 & 90.0 \\
& Wanita & 5 & 10.0 & 10.0 & 100.0 \\
& Total & 50 & 100.0 & 100.0 & \\
\hline
\end{tabular}

Sumber: Output SPSS

Berdasarkan tabel tersebut, dapat diketahui bahwa 45 responden atau $90 \%$ jumlahnya adalah pria, 5 responden atau $10 \%$ jumlahnya adalah wanita.

\section{c. Profil Responden Berdasarkan Usia}




\begin{tabular}{|c|c|c|c|c|c|}
\hline & & Frequency & Percent & Valid Percent & $\begin{array}{l}\text { Cumulative } \\
\text { Percent }\end{array}$ \\
\hline \multirow[t]{4}{*}{ Valid } & > 40 Tahun & 2 & 4.0 & 4.0 & 4.0 \\
\hline & $<25$ tahun & 19 & 38.0 & 38.0 & 42.0 \\
\hline & 25 Tahun - 40 Tahun & 29 & 58.0 & 58.0 & 100.0 \\
\hline & Total & 50 & 100.0 & 100.0 & \\
\hline
\end{tabular}

Sumber: Output SPSS

Berdasarkan data responden pada tabel tersebut, dapat diketahui bahwa 2 responden atau $4 \%$ memiliki rentang usia > 40 tahun, 19 responden atau $38 \%$ memiliki rentang usia $<25$ tahun, dan 29 responden atau 58\% di usia $25-40$ tahun.

\section{Uji Validitas}

Uji Validitas ini dilakukan dengan membandingkan nilai $r_{\text {hitung }}$ dengan $r_{\text {tabel }}$ untuk df $=\mathrm{n}-2$. Dalam penelitian ini $\mathrm{df}=50-2$ atau $\mathrm{df}=48$ dengan $\alpha: 0.05$ didapat $r_{\text {tabel }}$ sebesar $\mathbf{0 , 2 7 8}$, maka instrumen atau item-item pernyataan berkorelasi signifikan terhadap skor total atau dinyatakan valid.

\begin{tabular}{|c|c|c|c|c|c|}
\hline \multirow{4}{*}{$\mathbf{4} \mathbf{d f}=\mathbf{( N - 2 )}$} & \multicolumn{5}{|c|}{ Tingkat signifikansi untuk uji satu arah } \\
\cline { 2 - 6 } & $\mathbf{0 . 0 5}$ & $\mathbf{0 . 0 2 5}$ & $\mathbf{0 . 0 1}$ & $\mathbf{0 . 0 0 5}$ & $\mathbf{0 . 0 0 0 5}$ \\
\cline { 2 - 6 } & $\mathbf{0 . 1}$ & $\mathbf{0 . 0 5}$ & $\mathbf{0 . 0 2}$ & $\mathbf{0 . 0 1}$ & $\mathbf{0 . 0 0 1}$ \\
\hline $\mathbf{4 7}$ & 0.2377 & 0.2816 & 0.3314 & 0.3646 & 0.4557 \\
\hline $\mathbf{4 8}$ & 0.2353 & $\mathbf{0 . 2 7 8 7}$ & 0.3281 & 0.3610 & 0.4514 \\
\hline
\end{tabular}

Berdasarkan tabel tersebut didapat nilai $r_{\text {tabel }}$ sebesar 0,278. Jika $r_{\text {hitung }}$ (per item) > $\mathrm{r}_{\text {tabel }}$ berarti pernyataan tersebut dikatakan valid. Hasil uji validitas untuk $\mathrm{r}_{\text {hitung }}$ (per item) dapat dilihat dari hasil output SPSS 22 pada kolom Corrected Item-Total Correlation seperti yang disajikan pada tabel sebagai berikut :

\section{Uji Validitas Variabel Kesadaran Wajib Pajak (X1)}

\begin{tabular}{|c|c|c|c|c|c|c|}
\hline & & $\mathrm{X} 1.1$ & $X 1.2$ & $X 1.3$ & $\mathrm{X} 1.4$ & $\begin{array}{c}\text { TOTAL } \\
\text { X1 }\end{array}$ \\
\hline \multirow[t]{3}{*}{$X 1.1$} & $\begin{array}{l}\text { Pearson } \\
\text { Correlation }\end{array}$ & 1 & $.420^{* *}$ & $.369^{* \star}$ & .151 & $.617^{\star *}$ \\
\hline & Sig. (2-tailed) & & .002 & .008 & .295 & .000 \\
\hline & $\mathrm{N}$ & 50 & 50 & 50 & 50 & 50 \\
\hline \multirow[t]{3}{*}{$X 1.2$} & $\begin{array}{l}\text { Pearson } \\
\text { Correlation }\end{array}$ & $.420^{* *}$ & 1 & $.578^{\star *}$ & $.361^{\star *}$ & $.781^{\star *}$ \\
\hline & Sig. (2-tailed) & .002 & & .000 & .010 & .000 \\
\hline & $\mathrm{N}$ & 50 & 50 & 50 & 50 & 50 \\
\hline \multirow[t]{3}{*}{$\mathrm{X} 1.3$} & $\begin{array}{l}\text { Pearson } \\
\text { Correlation }\end{array}$ & $.369^{* *}$ & $.578^{* *}$ & 1 & $.505^{\star \star}$ & $.833^{* *}$ \\
\hline & Sig. (2-tailed) & .008 & .000 & & .000 & .000 \\
\hline & $\mathrm{N}$ & 50 & 50 & 50 & 50 & 50 \\
\hline \multirow[t]{2}{*}{$X 1.4$} & $\begin{array}{l}\text { Pearson } \\
\text { Correlation }\end{array}$ & .151 & $.361^{* *}$ & $.505^{\star \star}$ & 1 & $.724^{* *}$ \\
\hline & Sig. (2-tailed) & .295 & .010 & .000 & & .000 \\
\hline
\end{tabular}

Jurnal Ilmiah Akuntansi dan Ekonomi Volume. 5 Nomor. 2, Agustus 2020 Hal. 110 


\begin{tabular}{|ll|r|r|r|r|r|} 
& $\mathrm{N}$ & 50 & 50 & 50 & 50 & 50 \\
\hline TOTAL & Pearson & $.617^{* *}$ & $.781^{* *}$ & $.833^{* *}$ & $.724^{* *}$ & 1 \\
X1 & Correlation & & & & & \\
& Sig. (2-tailed) & .000 & .000 & .000 & .000 & \\
& $\mathrm{~N}$ & 50 & 50 & 50 & 50 & 50 \\
\hline
\end{tabular}

Sumber: Output SPSS

Pernyataan $1:$ Nilai $0,617>0,278=$ valid .

Pernyataan 2 : Nilai $0,781>0,278=$ valid .

Pernyataan 3 : Nilai $0,833>0,278=$ valid .

Pernyataan 4 : Nilai $0,724>0,278=$ valid .

Hasil Uji Validitas Variabel Modernisasi Sistem Perpajakan (X2)

\begin{tabular}{|c|c|c|c|c|c|c|}
\hline & & $\mathrm{X} 2.1$ & $\mathrm{X} 2.2$ & $X 2.3$ & $\mathrm{X} 2.4$ & $\begin{array}{c}\text { TOTAL } \\
\times 2 \\
\end{array}$ \\
\hline \multirow[t]{3}{*}{$\mathrm{X} 2.1$} & $\begin{array}{l}\text { Pearson } \\
\text { Correlation }\end{array}$ & 1 & $.420^{* *}$ & $.369^{\star *}$ & .151 & $.671^{* *}$ \\
\hline & Sig. (2-tailed) & & .002 & .008 & .295 & .000 \\
\hline & $\mathrm{N}$ & 50 & 50 & 50 & 50 & 50 \\
\hline \multirow[t]{3}{*}{$\mathrm{X} 2.2$} & $\begin{array}{l}\text { Pearson } \\
\text { Correlation }\end{array}$ & & 1 & $.578^{\star \star}$ & & $.781^{* *}$ \\
\hline & Sig. (2-tailed) & .002 & & .000 & .010 & .000 \\
\hline & $\mathrm{N}$ & 50 & 50 & 50 & 50 & 50 \\
\hline \multirow[t]{3}{*}{$\mathrm{X} 2.3$} & $\begin{array}{l}\text { Pearson } \\
\text { Correlation }\end{array}$ & & & 1 & $.505^{\star \star}$ & $.838^{* *}$ \\
\hline & Sig. (2-tailed) & .008 & .000 & & .000 & .000 \\
\hline & $\mathrm{N}$ & 50 & 50 & 50 & 50 & 50 \\
\hline \multirow[t]{3}{*}{$\overline{X 2.4}$} & $\begin{array}{l}\text { Pearson } \\
\text { Correlation }\end{array}$ & .151 & & $.505^{\star \star}$ & 1 & \\
\hline & Sig. (2-tailed) & .295 & .010 & .000 & & .000 \\
\hline & $\mathrm{N}$ & 50 & 50 & 50 & 50 & 50 \\
\hline \multirow[t]{3}{*}{$\begin{array}{l}\text { TOTAL } \\
\text { X2 }\end{array}$} & $\begin{array}{l}\text { Pearson } \\
\text { Correlation }\end{array}$ & $.617^{\star \star}$ & $.781^{\star \star}$ & $.833^{* *}$ & $.724^{* *}$ & 1 \\
\hline & Sig. (2-tailed) & .000 & .000 & .000 & .000 & \\
\hline & $\mathrm{N}$ & 50 & 50 & 50 & 50 & 50 \\
\hline
\end{tabular}

Sumber: Output SPSS

Pernyataan 1 : Nilai $0,671>0,278=$ valid .

Pernyataan 2 : Nilai $0,781>0,278=$ valid .

Pernyataan 3 : Nilai $0,838>0,278=$ valid .

Pernyataan 4 : Nilai $0,742>0,278=$ valid 
Uji Validitas Variabel Sanksi Perpajakan (X3)

\begin{tabular}{|c|c|c|c|c|c|c|}
\hline & & $\mathrm{X} 3.1$ & $\mathrm{X} 3.2$ & $\times 3.3$ & $\times 3.4$ & $\begin{array}{c}\text { TOTAL } \\
\times 3 \\
\end{array}$ \\
\hline \multirow[t]{3}{*}{ X3.1 } & $\begin{array}{l}\text { Pearson } \\
\text { Correlation }\end{array}$ & 1 & $.398^{\star *}$ & .114 & $.362^{\star *}$ & $.603^{* *}$ \\
\hline & Sig. (2-tailed) & & .004 & .431 & .010 & .000 \\
\hline & $\mathrm{N}$ & 50 & 50 & 50 & 50 & 50 \\
\hline \multirow[t]{3}{*}{ X3.2 } & $\begin{array}{l}\text { Pearson } \\
\text { Correlation }\end{array}$ & & 1 & $.425^{* *}$ & .264 & $.739^{* *}$ \\
\hline & Sig. (2-tailed) & .004 & & .002 & .064 & .000 \\
\hline & $\mathrm{N}$ & 50 & 50 & 50 & 50 & 50 \\
\hline \multirow[t]{3}{*}{ X3.3 } & $\begin{array}{l}\text { Pearson } \\
\text { Correlation }\end{array}$ & .114 & $.425^{* *}$ & 1 & .052 & $.709^{* *}$ \\
\hline & Sig. (2-tailed) & .431 & .002 & & .720 & .000 \\
\hline & $\mathrm{N}$ & 50 & 50 & 50 & 50 & 50 \\
\hline \multirow[t]{3}{*}{ X3.4 } & $\begin{array}{l}\text { Pearson } \\
\text { Correlation }\end{array}$ & $.362^{* *}$ & .264 & .052 & 1 & .712 \\
\hline & Sig. (2-tailed) & .010 & .064 & .720 & & .441 \\
\hline & $\mathrm{N}$ & 50 & 50 & 50 & 50 & 50 \\
\hline \multirow[t]{3}{*}{$\begin{array}{l}\text { TOTAL } \\
\text { X3 }\end{array}$} & $\begin{array}{l}\text { Pearson } \\
\text { Correlation }\end{array}$ & $.603^{\star \star}$ & $.739^{\star *}$ & $.709^{\star \star}$ & .112 & 1 \\
\hline & Sig. (2-tailed) & .000 & .000 & .000 & .441 & \\
\hline & $\mathrm{N}$ & 50 & 50 & 50 & 50 & 50 \\
\hline
\end{tabular}

Sumber: Output SPSS

Pernyataan 1 : Nilai $0,603>0,278=$ valid .

Pernyataan 2 : Nilai $0,739>0,278=$ valid .

Pernyataan 3 : Nilai 0,709 > 0,278=valid .

Pernyataan 4 : Nilai $0,712>0,278=$ valid .

Uji Validitas Variabel Kepatuhan Wajib Pajak (Y)

\begin{tabular}{|c|c|c|c|c|c|c|}
\hline & & Y.1 & Y.2 & Y.3 & Y.4 & TOTAL Y \\
\hline \multirow[t]{3}{*}{ Y.1 } & $\begin{array}{l}\text { Pearson } \\
\text { Correlati } \\
\text { on }\end{array}$ & 1 & $.287^{*}$ & .103 & .109 & $.552^{*}$ \\
\hline & $\begin{array}{l}\text { Sig. (2- } \\
\text { tailed) }\end{array}$ & & .043 & .479 & .453 & .000 \\
\hline & $\mathrm{N}$ & 50 & 50 & 50 & 50 & 50 \\
\hline \multirow[t]{3}{*}{ Y.2 } & $\begin{array}{l}\text { Pearson } \\
\text { Correlati } \\
\text { on }\end{array}$ & $.287^{*}$ & 1 & .270 & .048 & $.706^{* *}$ \\
\hline & $\begin{array}{l}\text { Sig. (2- } \\
\text { tailed) }\end{array}$ & .043 & & .058 & .741 & .000 \\
\hline & $\mathrm{N}$ & 50 & 50 & 50 & 50 & 50 \\
\hline Y.3 & $\begin{array}{l}\text { Pearson } \\
\text { Correlati } \\
\text { on }\end{array}$ & .103 & .270 & 1 & .122 & $.673^{* *}$ \\
\hline
\end{tabular}




\begin{tabular}{|c|c|c|c|c|c|c|}
\hline & $\begin{array}{l}\text { Sig. (2- } \\
\text { tailed) } \\
\mathrm{N}\end{array}$ & $\begin{array}{r}.479 \\
50\end{array}$ & $\begin{array}{r}.058 \\
50\end{array}$ & 50 & $\begin{array}{r}.398 \\
50\end{array}$ & $\begin{array}{r}.000 \\
50\end{array}$ \\
\hline \multirow[t]{3}{*}{ Y.4 } & $\begin{array}{l}\text { Pearson } \\
\text { Correlati } \\
\text { on }\end{array}$ & 109 & .048 & . 122 & 1 & $.394^{* *}$ \\
\hline & $\begin{array}{l}\text { Sig. (2- } \\
\text { tailed) }\end{array}$ & .453 & .741 & .398 & & .005 \\
\hline & $\mathrm{N}$ & 50 & 50 & 50 & 50 & 50 \\
\hline \multirow[t]{3}{*}{$\begin{array}{l}\text { TOTAL } \\
Y\end{array}$} & $\begin{array}{l}\text { Pearson } \\
\text { Correlati } \\
\text { on }\end{array}$ & $.552^{* *}$ & $.706^{* *}$ & $.673^{* *}$ & $.394^{* *}$ & 1 \\
\hline & $\begin{array}{l}\text { Sig. (2- } \\
\text { tailed) }\end{array}$ & .000 & .000 & .000 & .005 & \\
\hline & $\mathrm{N}$ & 50 & 50 & 50 & 50 & 50 \\
\hline
\end{tabular}

Sumber: Output SPSS

Pernyataan $1:$ Nilai $0,552>0,278=$ valid .

Pernyataan $2:$ Nilai $0,706>0,278=$ valid .

Pernyataan 3 : Nilai $0,673>0,278=$ valid .

Pernyataan 4 : Nilai 0, $394>0,278=$ valid .

\section{Uji Reliabilitas}

Variabel kesadaran wajib pajak (X1)

\begin{tabular}{|r|r|}
\hline $\begin{array}{c}\text { Cronbach's } \\
\text { Alpha }\end{array}$ & N of Items \\
\hline .720 & 4 \\
\hline
\end{tabular}

Variabel modernisasi sistem perpajakan (X2)

\begin{tabular}{|r|r|}
\hline $\begin{array}{c}\text { Cronbach's } \\
\text { Alpha }\end{array}$ & N of Items \\
\hline .721 & 4 \\
\hline
\end{tabular}

Variabel sanksi perpajakan (X3)

\begin{tabular}{|r|r|}
\hline $\begin{array}{c}\text { Cronbach's } \\
\text { Alpha }\end{array}$ & N of ltems \\
\hline .723 & 4 \\
\hline
\end{tabular}

Variabel kepatuhan wajib pajak (Y)

\begin{tabular}{|r|r|}
\hline $\begin{array}{l}\text { Cronbach's } \\
\text { Alpha }\end{array}$ & N of Items \\
\hline .730 & 4 \\
\hline
\end{tabular}

1. Cronbach's Alpha 0,720 >0,70.Hal ini dapat disimpulkan bahwa pernyataanpernyataan dalam variabel kesadaran adalah reliable, artinya bahwa hasil pengukuran variabel kesadaran wajib pajak adalah konsisten. 
2. Cronbach's Alpha 0,721 >0,70.Hal ini dapat disimpulkan bahwa pernyataanpernyataan dalam variabel modernisasi adalah reliable, artinya bahwa hasil pengukuran variabel modernisasi sistem perpajakan adalah konsisten.

3. Cronbach's Alpha 0,723 > 0,70.Hal ini dapat disimpulkan bahwa pernyataanpernyataan dalam variabel sanksi perpajakan adalah reliable, artinya bahwa hasil pengukuran variabel sanksi perpajakan adalah konsisten.

4. Cronbach's Alpha 0,730 >0,70.Hal ini dapat disimpulkan bahwa pernyataanpernyataan dalam variabel kepatuhan wajib pajak reliable, artinya bahwa hasil pengukuran variabel kepatuhan wajib pajak orang pribadi adalah konsisten.

\section{Uji Asumsi Klasik}

Uji asumsi klasik meliputi :

\section{a. Uji Normalitas}

One-Sample Kolmogorov-Smirnov Test
\begin{tabular}{|ll|r|}
\hline \multicolumn{1}{|c|}{} & $\begin{array}{c}\text { Unstandardized } \\
\text { Residual }\end{array}$ \\
\hline Normal Parameters & \\
& Mean & 50 \\
Most Extreme Differences & Std. Deviation & .0000000 \\
& Absolute & 1.75255114 \\
& Positive & .094 \\
Test Statistic & Negative & .065 \\
Asymp. Sig. (2-tailed) & & -.094 \\
\end{tabular}

Sumber: Output SPSS

Berdasarkan hasil uji normalitas diperoleh, untuk hasil variabel kesadaran wajib pajak (X1), modernisasi sistem perpajakan (X2), sanksi perpajakan (X3), dan kepatuhan wajib pajak (Y) yaitu 0,200>0,05 maka dapat disimpulkan bahwa analisis Ha diterima, artinya data residual berdistribusi normal.

\section{b. Uji Heteroskedastisitas}

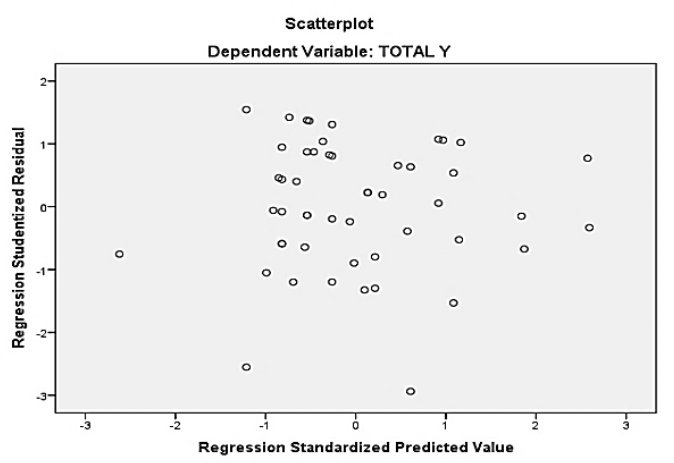

Berdasarkan Gambar Grafik Scatterplot di atas menunjukkan bahwa data tersebar di atas dan di bawah angka 0 (nol) pada sumbu Y dan untuk pola diatas masih diragukan sehingga untuk memperkuat uji heteroskedastisitas menggunakan Uji Glesjer, dengan hasil sebagai berikut ini :

\section{Uji Glesjer}




\begin{tabular}{|c|c|c|c|c|c|c|}
\hline \multirow{2}{*}{\multicolumn{2}{|c|}{ Model }} & \multicolumn{2}{|c|}{ Unstandardized Coefficients } & \multirow{2}{*}{$\begin{array}{l}\text { Standardized } \\
\text { Coefficients } \\
\text { Beta }\end{array}$} & \multirow[b]{2}{*}{$\mathrm{T}$} & \multirow[b]{2}{*}{ Sig. } \\
\hline & & $\mathrm{B}$ & Std. Error & & & \\
\hline \multirow[t]{4}{*}{1} & (Constant) & 1.169 & .941 & & 1.242 & .220 \\
\hline & TOTAL X1 & -.094 & .050 & -.308 & -1.890 & .065 \\
\hline & TOTAL X2 & .102 & .069 & .288 & 1.491 & .143 \\
\hline & TOTAL X3 & .076 & .062 & .246 & 1.229 & .225 \\
\hline
\end{tabular}

Sumber: Output SPSS

Hasil output dapat dijelaskan sebagai berikut:

a. Variabel kesadaran wajib pajak (X1) memiliki nilai sig. 0,065>0,05 kesimpulan tidak terjadi heteroskedastisitas.

b. Variabel modernisasi sistem perpajakn (X2) memiliki nilai sig. 0,143>0,05 kesimpulan tidak terjadi heteroskedastisitas,

c. Variabel sanksi perpajakan (X3) memiliki nilai sig. 0,225 >0,05 kesimpulan tidak terjadi heteroskedastisitas.

\section{Uji Autokorelasi}

Model regresi yang baik adalah regresi yang bebas dari autokorelasi. Ada beberapa cara yang dapat digunakan untuk mendeteksi ada atau tidaknya autokorelasi. Metode pengujian yang sering digunakan adalah uji Durbin-Watson (DW-test) dengan ketentuan sebagai berikut :

Tabel Durbin Watson

\begin{tabular}{|c|c|c|c|c|c|c|c|c|c|c|}
\hline \multirow[t]{2}{*}{$n$} & \multicolumn{2}{|c|}{$\begin{array}{c}k= \\
1\end{array}$} & \multicolumn{2}{|c|}{$\begin{array}{l}\mathrm{k} \\
= \\
2\end{array}$} & \multicolumn{2}{|c|}{$\begin{array}{c}k= \\
3\end{array}$} & \multicolumn{2}{|c|}{$\begin{array}{c}k= \\
4\end{array}$} & \multicolumn{2}{|r|}{$\begin{array}{l}\mathrm{k} \\
= \\
5\end{array}$} \\
\hline & DI & Du & DI & Du & DI & $d U$ & $\mathrm{dL}$ & Du & $\mathrm{dL}$ & dU \\
\hline 46 & 1.4814 & 1.5700 & 1.4368 & 1.6176 & 1.3912 & 1.6677 & 1.3448 & 1.7201 & 1.2976 & 1.7748 \\
\hline 47 & 1.4872 & 1.5739 & 1.4435 & 1.6204 & 1.3989 & 1.6692 & 1.3535 & 1.7203 & 1.3073 & 1.7736 \\
\hline 48 & 1.4928 & 1.5776 & 1.4500 & 1.6231 & 1.4064 & 1.6708 & 1.3619 & 1.7206 & 1.3167 & 1.7725 \\
\hline 49 & 1.4982 & 1.5813 & 1.4564 & 1.6257 & 1.4136 & 1.6723 & 1.3701 & 1.7210 & 1.3258 & 1.7716 \\
\hline 50 & 1.5035 & 1.5849 & 1.4625 & 1.6283 & 1.4206 & 1.6739 & 1.3779 & 1.7214 & 1.3346 & 1.7708 \\
\hline 51 & 1.5086 & 1.5884 & 1.4684 & 1.6309 & 1.4273 & 1.6754 & 1.3855 & 1.7218 & 1.3431 & 1.7701 \\
\hline 52 & 1.5135 & 1.5917 & 1.4741 & 1.6334 & 1.4339 & 1.6769 & 1.3929 & 1.7223 & 1.3512 & 1.7694 \\
\hline 53 & 1.5183 & 1.5951 & 1.4797 & 1.6359 & 1.4402 & 1.6785 & 1.4000 & 1.7228 & 1.3592 & 1.7689 \\
\hline
\end{tabular}

Berdasarkan Tabel tersebut, didapatkan nilai dL sebesar 1.4206 dan dU sebesar 1.6739 dan untuk mengetahui apakah terdapat autokorelasi dalam model regresi dapat dilihat pada Tabel 4.13 berikut: 


\section{Hasil Uji Autokorelasi}

\begin{tabular}{|l|r|r|r|r|r|}
\hline Model & $\mathrm{R}$ & R Square & $\begin{array}{c}\text { Adjusted R } \\
\text { Square }\end{array}$ & $\begin{array}{c}\text { Std. Error of the } \\
\text { Estimate }\end{array}$ & Durbin-Watson \\
\hline 1 & $.709^{\mathrm{a}}$ & .503 & .471 & 1.179 & 1.904 \\
\hline
\end{tabular}

\section{Sumber: Output SPSS}

Dari Tabel diatas didapat nilai DW yang dihasilkan dari model regresi adalah 1,904 lebih besar dari batas atas (dU) 1,673 dan kurang dari 2,327 (4-dU) atau $\mathrm{dU}<\mathrm{d}<4-\mathrm{dU}$, maka dapat disimpulkan bahwa tidak bisa menolak Ho yang menyatakan bahwa tidak ada autokorelasi positif atau negatif atau dapat disimpulkan tidak terdapat autokorelasi.

\section{Uji Multikolinearitas}

\section{Hasil Uji Multikolinearitas}

\begin{tabular}{|ll|r|c|}
\hline \multirow{2}{*}{ Model } & \multicolumn{2}{|c|}{ Collinearity Statistics } \\
\cline { 2 - 3 } & Kolerance & \multicolumn{1}{c|}{ VIF } \\
\hline 1 & Kesadaran Wajib Pajak & .678 & 1.474 \\
& Modernisasi Sistem & .647 & 1.546 \\
Perpajakan & .603 & 1.658 \\
& Sanksi Perpajakan & .603
\end{tabular}

Sumber: Output SPSS

1. Kesadaran wajib pajak $\left(\mathrm{X}_{1}\right)$

Tolerance $0,678>0,10$ dan VIF $1,474<10$, maka tidak terjadi multikolinearitas.

2. Modernisasi sistem perpajakan $\left(\mathrm{X}_{2}\right)$

Tolerance $0,647>0,10$ dan VIF $1,546<10$, maka tidak terjadi multikolinearitas.

3. Sanksi perpajakan $\left(\mathrm{X}_{3}\right)$

Tolerance $0,603>0,10$ dan VIF $1,658<10$, maka tidak terjadi multikolinearitas.

\section{Analisis Regresi Linier Berganda}

\section{Hasil Uji Analisis Regresi Linear Berganda}

\begin{tabular}{|rl|r|r|r|r|r|}
\hline & & \multicolumn{2}{|c|}{$\begin{array}{c}\text { Unstandardized } \\
\text { Coefficients }\end{array}$} & $\begin{array}{c}\text { Standardized } \\
\text { Coefficients }\end{array}$ & & \\
\cline { 3 - 5 } & \multicolumn{1}{c|}{ Model } & \multicolumn{1}{c|}{ B } & Std. Error & \multicolumn{1}{c|}{ Beta } & \multicolumn{1}{c|}{ T } & Sig. \\
\hline 1 & (Constant) & 15.525 & 2.905 & & 5.344 & .000 \\
& Kesadaran WP & .393 & .171 & .393 & 2.296 & .026 \\
& Modernisasi Pajak & .061 & .162 & .063 & .374 & .710 \\
& Sanksi Perpajakan & .220 & .166 & .235 & 1.528 & .191 \\
\hline
\end{tabular}

Sumber: Output SPSS

1. Nilai a (konstanta) pada hasil pengujian di atas adalah sebesar 15.525 yang berarti bahwa jika variabel independen (kesadaran wajib pajak, modernisasi perpajakan, sanksi perpajakan) konstan, maka kepatuhan wajib pajak orang pribadi akan mengalami kenaikan sebesar 15.525. Nilai konstanta sebesar 
15.525 menunujukkan nilai murni dari variabel kepatuhan wajib pajak orang pribadi (dependen) tanpa di pengaruhi variabel independen.

2. Koefisien regresi pengaruh kesadaran wajib pajak adalah sebesar 0,393 dimana angka ini menujukkan bahwa setiap peningkatan variabel pengaruh kesadaran wajib pajak sebesar satu-satuan, maka akan meningkatkan kepatuhan wajib pajak orang pribadi sebesar 0,393 Koefisien bernilai positif artinya terdapat hubungan positif antara pengaruh kesadaran wajib pajak. Semakin meningkat kesadaran maka akan meningkatkan kepatuhan wajib pajak orang pribadi.

3. Koefisien regresi modernisasi perpajakan adalah sebesar 0,061 dimana angka ini menujukkan bahwa setiap peningkatan variabel modernisasi perpajakan sebesar satu-satuan, maka akan meningkatkan kepatuhan wajib pajak orang pribadi sebesar 0,061. Koefisien bernilai positif artinya terdapat hubungan positif antara modernisasi perpajakan. Semakin berpengsaruh modernisasi perpajakan, maka akan meningkatkan kepatuhan wajib pajak orang pribadi.

4. Koefisien regresi sanksi perpajakan adalah sebesar 0,220 dimana angka ini menujukkan bahwa setiap peningkatan variabel sanksi perpajakan sebesar satusatuan, maka akan meningkatkan kepatuhan wajib pajak orang pribadi sebesar 0,220 . Koefisien bernilai positif artinya terdapat hubungan positif antara sanksi perpajakan. Semakin berpengaruh sanksi perpajakan, maka akan meningkatkan kepatuhan wajib pajak orang pribadi.

\section{Uji Hipotesis}

\section{a. Uji Persial t}

Tabel t untuk df 41-48

\begin{tabular}{|c|c|c|c|c|c|c|c|}
\hline Pr & $\mathbf{0 . 2 5}$ & $\mathbf{0 . 1 0}$ & $\mathbf{0 . 0 5}$ & $\mathbf{0 . 0 2 5}$ & $\mathbf{0 . 0 1}$ & $\mathbf{0 . 0 0 5}$ & $\mathbf{0 . 0 0 1}$ \\
$\mathbf{D f}$ & $\mathbf{0 . 5 0}$ & $\mathbf{0 . 2 0}$ & $\mathbf{0 . 1 0}$ & $\mathbf{0 . 0 5 0}$ & $\mathbf{0 . 0 2}$ & $\mathbf{0 . 0 1 0}$ & $\mathbf{0 . 0 0 2}$ \\
\hline $\mathbf{4 1}$ & 0.68052 & 1.30254 & 1.68288 & 2.01954 & 2.42080 & 2.70118 & 3.30127 \\
$\mathbf{4 2}$ & 0.68038 & 1.30204 & 1.68195 & 2.01808 & 2.41847 & 2.69807 & 3.29595 \\
$\mathbf{4 3}$ & 0.68024 & 1.30155 & 1.68107 & 2.01669 & 2.41625 & 2.69510 & 3.29089 \\
$\mathbf{4 4}$ & 0.68011 & 1.30109 & 1.68023 & 2.01537 & 2.41413 & 2.69228 & 3.28607 \\
$\mathbf{4 5}$ & 0.67998 & 1.30065 & 1.67943 & 2.01410 & 2.41212 & 2.68959 & 3.28148 \\
$\mathbf{4 6}$ & 0.67986 & 1.30023 & 1.67866 & $\mathbf{2 . 0 1 2 9 0}$ & 2.41019 & 2.68701 & 3.27710 \\
$\mathbf{4 7}$ & 0.67975 & 1.29982 & 1.67793 & 2.01174 & 2.40835 & 2.68456 & 3.27291 \\
$\mathbf{4 8}$ & 0.67964 & 1.29944 & 1.67722 & 2.01063 & 2.40658 & 2.68220 & 3.26891
\end{tabular}

Sumber :Tabel t (Ghozali, 2016)

Dari tabel diatas diperoleh $\mathrm{t}_{\text {tabel }}$ sebesar 2.0129 sedangkan sebesar $\mathrm{t}_{\text {hitung }}$ dapat dilihat dari hasil output SPSS pada tabel sebagai berikut: 
Hasil Uji Parsial (t)

\begin{tabular}{|c|c|c|c|c|c|c|}
\hline & \multirow[b]{2}{*}{ Model } & \multicolumn{2}{|c|}{ Unstandardized Coefficients } & \multirow{2}{*}{$\begin{array}{c}\begin{array}{c}\text { Standardized } \\
\text { Coefficients }\end{array} \\
\text { Beta } \\
\end{array}$} & \multirow[b]{2}{*}{$\mathrm{T}$} & \multirow[b]{2}{*}{ Sig. } \\
\hline & & B & Std. Error & & & \\
\hline \multirow[t]{4}{*}{1} & (Constant) & 15.525 & 2.905 & & 5.344 & .000 \\
\hline & Kesadaran WP & .393 & .171 & .393 & 2.296 & .026 \\
\hline & Modernisasi Pajak & .061 & .162 & .063 & .374 & .710 \\
\hline & Sanksi Perpajakan & .220 & .166 & .235 & 1.528 & .191 \\
\hline
\end{tabular}

Sumber: Output SPSS

1. Berdasarkan tabel diatas terlihat bahwa variabel kesadaran wajib pajak memiliki nilai $t_{\text {hitung }}>t_{\text {tabel }}(2.296>2.0129)$ dan memiliki nilai signifikasi 0,026 yang artinya sig $<0,05$ Hal ini berarti menunjukkan bahwa keputusan yang diambil adalah menolak $\mathrm{H}_{0}$ dan menerima $\mathrm{H}_{\mathrm{a}}$, berarti kesadaran wajib pajak berpengaruh terhadap kepatuhan wajib pajak orang pribadi.

2. Berdasarkan tabel diatas terlihat variabel modernisasi sistem perpajakan memiliki nilai $t_{\text {hitung }}<\mathrm{t}_{\text {tabel }}(0,374<2.0129)$ dan nilai signifikasi 0,710 yang artinya sig $>0,05 \mathrm{Hal}$ ini berarti menunjukkan bahwa keputusan yang diambil adalah menerima $\mathrm{H}_{02}$ dan menolak $\mathrm{Ha}_{2}$, berarti modernisasi sistem perpajakan tidak berpengaruh terhadap kepatuhan wajib pajak orang pribadi.

3. Berdasarkan tabel 4.17 terlihat bahwa variabel sanksi perpajakan memiliki nilai thitung $<\mathrm{t}_{\text {tabel }}(1.528<2.01290)$ dan nilai signifikansi 0,191 yang artinya $>0,05$. Hal ini berarti menunjukkan bahwa keputusan yang diambil adalah menerima $\mathrm{H}_{03}$ dan menolak $\mathrm{H}_{a 3}$, berarti sanksi perpajakan pajak tidak berpengaruh terhadap kepatuhan wajib pajak orang pribadi.

\section{b. Uji Persial Secara Simultan (f)}

\section{Titik Persentase Distribusi F untuk Probabilitas}

$$
=0,05
$$

\begin{tabular}{|c|c|c|c|c|c|c|c|c|c|c|c|c|c|c|c|}
\hline \multirow[t]{2}{*}{$\begin{array}{r}\text { df untuk } \\
\text { penyebu } \\
t \text { (N2) }\end{array}$} & \multicolumn{15}{|c|}{$\begin{array}{l}\text { df untuk pembilang } \\
\text { (N1) }\end{array}$} \\
\hline & 1 & 2 & 3 & 4 & 5 & 6 & 7 & 8 & 9 & 10 & 11 & 12 & 13 & 14 & 15 \\
\hline 46 & 4.0 & 3.20 & 2.81 & 2.57 & 2.42 & 2.30 & 2.22 & 2.15 & 2.09 & 2.04 & 2.00 & 1.97 & 1.94 & 1.91 & 1.89 \\
\hline 47 & 4.0 & 3.20 & 2.80 & 2.57 & 2.41 & 2.30 & 2.21 & 2.14 & 2.09 & 2.04 & 2.00 & 1.96 & 1.93 & 1.91 & 1.88 \\
\hline
\end{tabular}

Sumber : Tabel f (Ghozali, 2016) 
Hasil Uji Simultan (f)

\begin{tabular}{|ll|r|r|r|r|r|}
\hline \multicolumn{1}{|c|}{ Model } & Sum of Squares & Df & Mean Square & F & Sig. \\
\hline 1 & Regression & 18.703 & 3 & 6.234 & 2.836 & $.000^{\mathrm{b}}$ \\
Residual & 156.177 & 46 & 3.395 & & \\
Total & 174.880 & 49 & & & \\
\hline
\end{tabular}

Sumber: Output SPSS

Berdasarkan tabel tersebut, dapat disimpulkan bahwa Fhitung $>$ Ftabel $(2.836>2.81)$ dan memiliki nilai signifikansi 0,000 yang artinya $<0,05$ dengan demikian Ho ditolak dan Ha diterima, sehingga terdapat pengaruh secara bersamasama (simultan) kesadaran wajib pajak, modernisasi perpajakan, dan sanksi perpajakan terhadap kepatuhan wajib pajak.

\section{c. Uji Determinasi (Uji $\mathbf{R}^{2}$ )}

Hasil Koefisien Determinasi $\left(\mathbf{R}^{2}\right)$

\begin{tabular}{|l|r|r|r|r|r|}
\hline Model & $\mathrm{R}$ & R Square & $\begin{array}{c}\text { Adjusted R } \\
\text { Square }\end{array}$ & $\begin{array}{c}\text { Std. Error of the } \\
\text { Estimate }\end{array}$ & Durbin-Watson \\
\hline 1 & $.709^{\mathrm{a}}$ & .503 & .471 & 1.179 & 1.904 \\
\hline
\end{tabular}

Sumber: Output SPSS

Diperoleh nilai $R$ Square sebesar 0,503 yang berarti menunjukan bahwa hubungan antara variabel dependen dan variabel independen adalah kuat karena angka tersebut lebih besar $>0,05$. Sedangkan adjusted $R$ square sebesar 0,471 atau sama dengan 47,1\%, hal tersebut mengartikan bahwa sebesar $47,1 \%$ pengaruh kepatuhan wajib pajak orang pribadi dapat dijelaskan oleh variabel kesadaran wajib pajak, modernisasi sistem perpajakan, dan sanksi perpajakan sedangkan sisanya $52,9 \%$ dapat dijelaskan oleh faktor-faktor penyebab lain yang tidak terdapat pada penelitian. Faktor lain dari indicator kepatuhan wajib pajak orang pribadi seperti: sosialisasi perpajakan, dan pemahaman wajib pajak.

\section{Kesimpulan}

\section{KESIMPULAN DAN SARAN}

\section{Parsial}

a. Berdasarkan dari hasil pengujian hipotesis yang telah dilakukan menunjukan bahwa variabel kesadaran wajib pajak (X1) berpengaruh terhadap kepatuhan wajib pajak (Y)

b. Berdasarkan dari hasil pengujian hipotesis yang telah dilakukan menunjukan bahwa variabel modernisasi sistem perpajakan (X2) tidak berpengaruh terhadap kepatuhan wajib pajak (Y)

c. Berdasarkan dari hasil pengujian hipotesis yang telah dilakukan menunjukan bahwa variabel sanksi perpajakan (X3) tidak berpengaruh terhadap kepatuhan wajib pajak (Y).

\section{Simultan}

Berdasarkan dari hasil pengujian hipotesis yang telah dilakukan menunjukan bahwa variabel kesadaran wajib pajak (X1), modernisasi sistem perpajakan 
(X2) dan sanksi perpajakan (X3) secara bersama-sama (simultan) berpengaruh terhadap kepatuhan wajib pajak (Y).

\section{Saran}

1. Diharapkan pada penelitian berikutnya mengenai kepatuhan wajib pajak yang akan datang sebaiknya menggunakan variabel independen lain untuk meningkatkan variasi penelitian dan mengetahui sebab-sebab lain yang dapat berpengaruh terhadap kepatuhan pajak.

2. Diharapkan untuk wajib pajak agar lebih sadar dan aktif dalam menjalankan segala bentuk regulasi perpajakan, agar pajak akan semakin optimal dimasa yang akan datang.

3. Bagi pemerintah diharapkan dapat memberikan sosialisasi perpajakan pada masyarakat dan meningkatkan pelayanan yang berkaitan dengan informasi maupun administrasi pajak sehingga wajib pajak terhindar dari sanksi perpajakan.

\section{DAFTAR PUSTAKA}

Adrian Sutedi.2011. Hukum Perpajakan. Jakarta:Sinar Grafika.

Anshari Ritonga.2011.Pengantar Ilmu Hukum Pajak \& Perpajakan Indonesia. Jakarta : Penerbit Pustaka El Manar.

Aristanti Widyaningsih.2013.Hukum Pajak Dan Perpajakan. Jakarta : Penerbit Alfa Beta.

Arinta Wulandari 2015. Pengaruh Penerapan Sanksi Perpajakan, Kesadaran Da Kepatuhan Wajib Pajak Dalam Membayar Pajak Bumi Dan Bangunan. Universitas Sebelas Maret Surakarta.

Basri, 2015. Pengaruh Pengetahuan Perpajakan, Dan Sanksi Perpajakan Terhadap Kepatuhan Wajib Pajak. Jurnal Akuntansi Trisakti Vol.4 Fakultas Ekonomi dan Bisnis.

Candra, 2013. Pengaruh Modernisasi Perpajakan,Kesadaran Wajib Pajak, Pelayanan Fiskus Terhadap Kepatuhan Wajib Pajak. Jurnal Akuntansi Vol.22 Universitas Udayana.

Delli Maria.2013. Pengaruh Modernisasi Sistem Administrasi Pajak Terhadap Tingkat Kepatuhan Pengusaha Kena Pajak. Jurnal Bisnis Darmajaya Vol.1 Fakultas Ekonomi

Erly Suandy.2016.Perencanaan Pajak.Jakarta:Salemba Empat.

Ghozali, Imam. 2016. Aplikasi Analisis Multivariate Dengan Program SPSS. Badan Penerbit Universitas Sumatera Diponegoro : Semarang

Gunadi.2013.Perpajakan Internasional.Jakarta:Salemba Empat

Liberti Pandiangan, 2014. Modernisasi Sistem Perpajakan Dan Administrasi Perpajakan.Jakarta:Penerbit PT Elex Media Komputindo.

Makarau Jonathan Bill, Lintje Kalangi .2018. Pengaruh Kesadaran Wajib Pajak Terhadap Kepatuhan Wajib Pajak Terhadap Kepatuhan Wajib Pajak Dalam Membayar Pajak Bumi Dan Bangunan. Universitas Sam Ratulangi Manado

Mardiasmo, 2016. Perpajakan.Yogyakarta:Penerbit Andi

Nurmalia Hasanah.2013.Efektifitas Pelaksanaan Self Assessment Dan Modernisasi Administrasi Pajak Terhadap Kualitas Pelayanan Pajak.Jurnal Akuntansi Fakultas Ekonomi Universitas Negeri Jakarta. 
Rahayu, Siti Kurnia. 2013. Perpajakan Indonesia . Konsep dan Aspek Formal. Yogyakarta : Graha Ilmu.

Ridwan dan Engkos Achmad Kuncoro.2014. Cara Menggunakan Dan Memakai Analisi Jalur. Alfabeta Bandung.

Sapriadi,2013. Pengaruh Kualitas Pelayanan Pajak, Sanksi Pajak Dan Kesadaran Wajib Pajak Terhadap Kepatuhan Wajib Pajak.Jurnal Akuntansi Fakultas Ekonomi Universitas Slamet Riyadi Surakarta.

Sugiono, 2016. Metode Penelitian Kuantitatif Kualitatif Dan R\&D. Bandung : Alfabeta

Tyas Pambudi Rahayu 2018. Pengaruh Pengetahuan Formal, Wajib Pajak Dan Kesadaran Wajib Pajak Terhadap Kepatuhan Wajib Pajak.

Waluyo, 2017. Perpajakan Indonesia. Jakarta : Salemba Empat.

Referensi Lainnya :

https://economy.okezone.com

https://ekonomi.bisnis.com

https://nasional.kontan.co.id

Keputusan Menteri Keuangan No. 544/KMK.04/2000

Undang-Undang No. 16 Tahun 2009 pasal 1 ayat 1 tentang Undang-Undang Ketentuan Umum dan Tata Cara Perpajakan

www. Pajak.go.id 